\title{
Culvert inventory and effects on fish assemblages in a Central Appalachian watershed
}

Ira O. Poplar-Jeffers

West Virginia University

Follow this and additional works at: https://researchrepository.wvu.edu/etd

\section{Recommended Citation}

Poplar-Jeffers, Ira O., "Culvert inventory and effects on fish assemblages in a Central Appalachian watershed" (2005). Graduate Theses, Dissertations, and Problem Reports. 2221.

https://researchrepository.wvu.edu/etd/2221

This Thesis is protected by copyright and/or related rights. It has been brought to you by the The Research Repository @ WVU with permission from the rights-holder(s). You are free to use this Thesis in any way that is permitted by the copyright and related rights legislation that applies to your use. For other uses you must obtain permission from the rights-holder(s) directly, unless additional rights are indicated by a Creative Commons license in the record and/ or on the work itself. This Thesis has been accepted for inclusion in WVU Graduate Theses, Dissertations, and Problem Reports collection by an authorized administrator of The Research Repository @ WVU. For more information, please contact researchrepository@mail.wvu.edu. 


\title{
Culvert Inventory and Effects on Fish Assemblages in a Central Appalachian Watershed
}

\author{
Ira O. Poplar-Jeffers \\ A Thesis \\ Submitted to the \\ Davis College of Agriculture, Forestry, and Consumer Sciences \\ at West Virginia University
}

in partial fulfillment of the requirements

for the degree of

\section{Master of Science \\ in \\ Wildlife and Fisheries Resources}

\author{
J. Todd Petty, Ph.D., Chair \\ James T. Anderson, Ph.D., Co-Chair \\ Steve Kite, Ph.D.
}

Wildlife and Fisheries Resources Program of the Division of Forestry

Morgantown, West Virginia

2005

Keywords: road crossing; culvert; movement barrier; fish passage;

culvert replacement; stream; Cheat River; fish assemblage; stream ecology; brook trout; population isolation 


\section{Abstract \\ Culvert Inventory and Effects on Fish Assemblages in a Central Appalachian Watershed \\ Ira Poplar-Jeffers}

We surveyed 120 state-owned culverts within the upper Cheat River basin, West Virginia, and used a fish passage evaluation filter to quantify passage barriers. We quantified the length of stream and weighted potential brook trout recruitment area isolated by each culvert. We also sampled fish communities upstream and downstream of 24 culverts to quantify the impacts of culvert-related isolation on fish assemblages. We found $69 \%$ of culverts to be completely impassable. We determined that $17 \%$ of the stream length and $23 \%$ of weighted potential recruitment area in the study area were isolated by impassable culverts. We found that impassable culverts are more likely to occur on small, steep, streams. We found that species richness and blacknose dace densities were negatively impacted upstream of culverts and culverts are more likely to impact species that are limited to larger streams, although culvertrelated impacts are more pronounced on small streams. 


\section{Table of Contents}

Section page

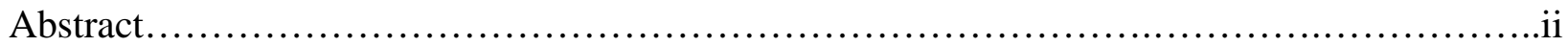

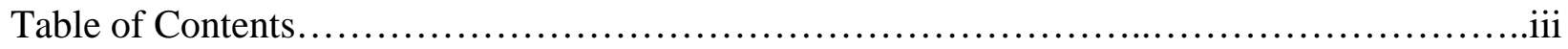

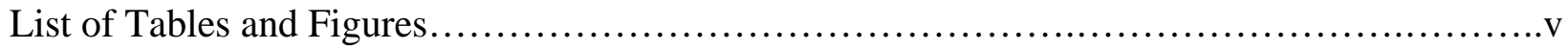

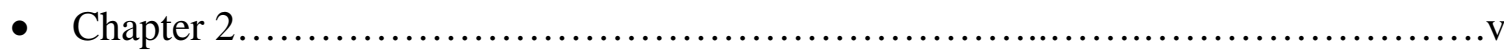

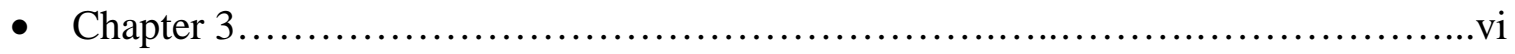

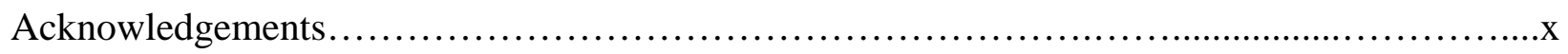

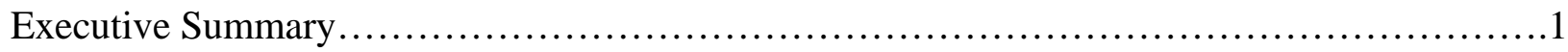

Chapter 1: Literature Review and Objectives..........................................4

• Abstract..................................................................4

• Literature Review............................................................

- Goals and Objectives...................................................13

• $\quad$ Literature Cited..................................................................

Chapter 2: Survey and Prioritization of Fish Passage Restoration Opportunities at Culvert Road Crossings in the Upper Cheat River Basin, West Virginia...............................19

• $\quad$ Abstract.................................................................19

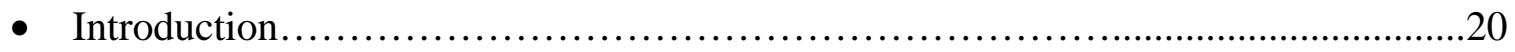

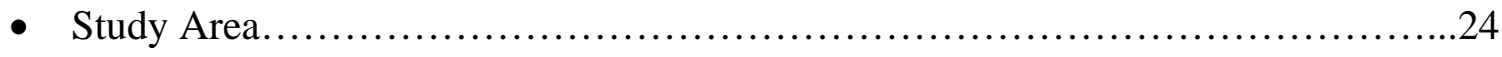

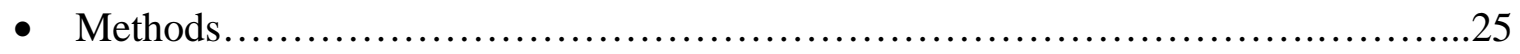

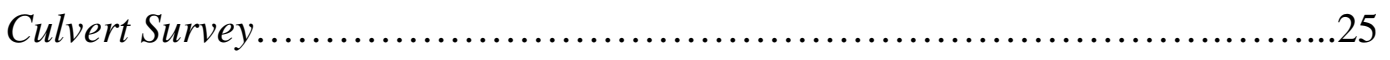

Culvert Classification.................................................28

Quantifying the Amount of Habitat Isolated by Culverts........................30

Culvert Replacement Priorities............................................31 


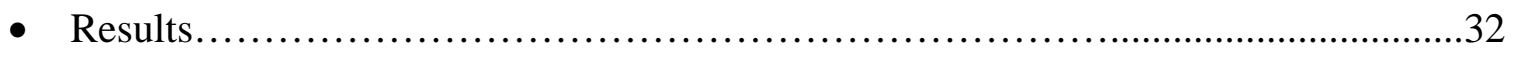

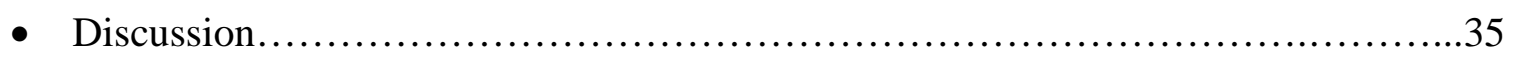

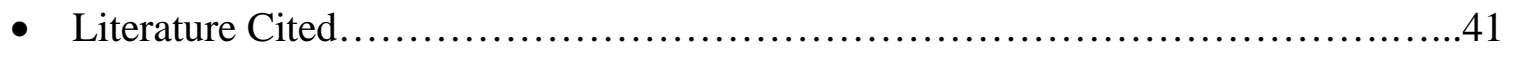

$\quad$ Tables..................................................................45

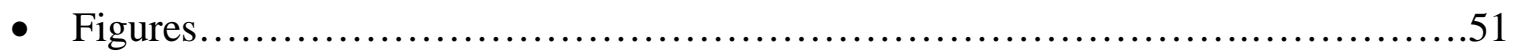

Chapter 3: Culvert Effects on Fish Assemblages in a Central Appalachian

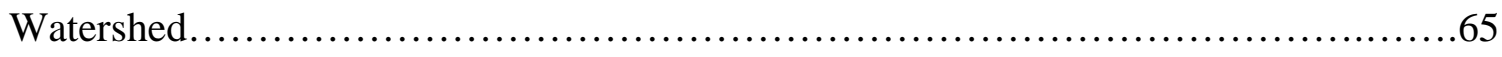

• Abstract...............................................................65

- Introduction.............................................................66

- Study Area............................................................ 72

• Methods...............................................................

Site Selection........................................................73

Data Collection....................................................... 74

Statistical Analysis..................................................79

$\quad$ Results................................................................ 85

• Discussion...........................................................96

- Conclusions and Implications............................................. 104

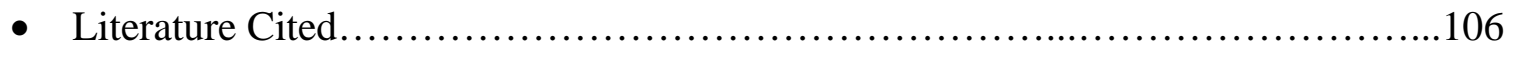

• Tables..............................................................111

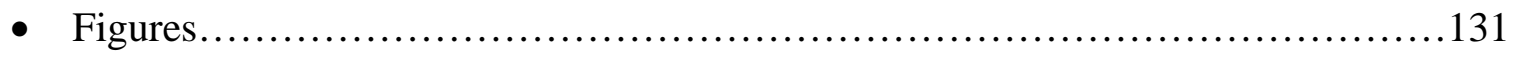

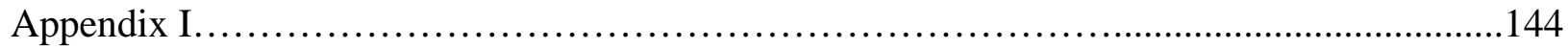

Appendix II..................................................................149 


\title{
List of Tables and Figures
}

\author{
Chapter 2
}

Tables

page

Table 1: Physical characteristics of the three sections of study during summer 2003 culvert surveys within the upper Cheat River basin

Table 2: List of the survey data collected at 120 culvert locations during the Summer of 2003.

Table 3: The top 20 culvert replacement priorities ranked based upon passage category and WPRA located upstream of each culvert.

Table 4: Length of stream and weight potential recruitment area (WPRA) located above all culverts, red and gray culverts only, red culverts only, as well as total available within

Figures

page

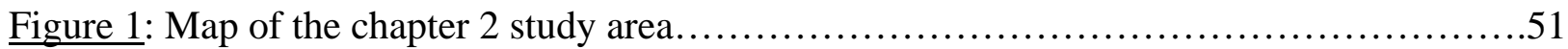

Figure 2: Green-Gray-Red fish passage evaluation filter of Love \& Taylor (2003).............52

Figure 3: Measurements used in the fish passage evaluation filter........................53

Figure 4: Histogram of the relative frequency of culverts within each fish passage category

Figure 5: Proportion of culverts within each study section and of all culverts surveyed that were categorized as "red."

Figure 6: Proportion of total culverts surveyed that violated $0,1,2,3,4$, and 5 of the major criteria from the fish passage evaluation filter.

Figure 7: Combinations of violations of the five filter criteria listed in Love and Taylor (2003)

Figure 8: Proportion of culverts that contained continuous streambed substrate versus the proportion that did not.

Figure 9: Proportion of culverts, by passage category, that did not contain a continuous layer of streambed substrate. .56

Figure 10: Proportion of culverts that had residual inlet and outlet depths greater than $0.15 \mathrm{~m}$ versus the proportion did not. 
Figure 11: Proportion, by passage category, of culverts that had a residual inlet or outlet depth of less than $0.15 \mathrm{~m}$.

Figure 12: a) Histogram showing inlet width-average active channel width ratio for all culverts surveyed in the study area in 2003. b) Relative cumulative frequency of inlet width-active channel width ratios for all culverts surveyed in the study area in 2003.

Figure 13: a)Histogram showing outlet hang height $(\mathrm{m})$ for all culverts surveyed within in the study area in 2003. b) Relative cumulative frequency of outlet hang height (m) for all culverts surveyed within the study area in 2003.

Figure 14: a) Histogram showing culvert slope (\%) for all culverts surveyed within the study area in 2003. b) Relative cumulative frequency of culvert slope (\%) for all culverts

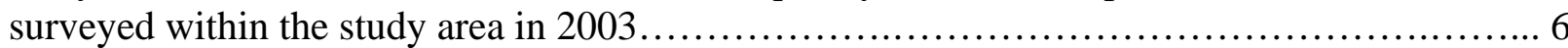

Figure 15: Box plots comparing the following variables between groups of "red," "green," and "gray" culverts: a) inlet width-ACW ratio, b) outlet hang height (m), c) culvert slope (\%), d) survey channel slope (\%), e) basin area at the culvert $\left(\mathrm{km}^{2}\right)$, and f) active channel width (m).

Figure 16: Cumulative proportional occurrence of all culverts and "red" culverts versus the following variables: a) inlet width-ACW ratio, b) outlet hang height (m), c) culvert slope (\%), d) survey channel slope (\%), e) basin area at the culvert $\left(\mathrm{km}^{2}\right)$, and f) active channel width (m)

Figure 17: Map of the chapter 2 study area highlighting stream segments isolated by impassable culverts.

Figure 18: Proportion of the length of stream and weighted potential spawning area located above red culverts within each watershed and the entire study area.....

Figure 19: WPRA loss extent vs. loss intensity due to habitat isolation by barrier culverts for each study section within the study area.

\section{Chapter 3}

\section{Tables}

Table 5: Physical characteristics of the three study sections within the upper Cheat River basin study area during summer 2004 fish assemblage sampling ....

Table 6: First pass capture probabilities, based upon triple pass collection techniques, on streams draining under $8 \mathrm{~km}^{2}$ for main species analyzed within this study 
Table 7: Results from pairwise two-tailed Wilcoxon signed ranks tests on water quality variables between upstream (US) and downstream (DS) culvert reaches for all abovebelow sites $(n=24)$. Water quality was no different upstream of culverts than downstream.

Table 8: A list of habitat variables and transformations used on respective datasets

Table 9: Correlation matrix including all transformed habitat variables.

Table 10: List of fish families and species sampled at all sites including the number of culvert sites where each species was found and the number of below-culvert and aboveculvert stream reaches where present.

Table 11: Results from pairwise two-tailed Wilcoxon signed ranks tests on fish species richness and species densities between upstream and downstream culvert reaches for all sites

Table 12: Results from principal components analysis of in-stream habitat variables

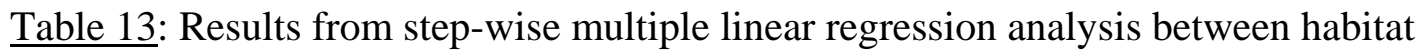
variables and fish species richness/species densities on reaches located upstream of culverts....

Table 14: Results from step-wise multiple linear regression analysis between habitat variables and fish species richness/species densities on reaches located downstream of culverts.

Table 15: Results from step-wise multiple linear regression analysis between principal components and fish species richness/species densities on reaches upstream of culverts

Table 16: Results from step-wise multiple linear regression analysis between principal components and fish species richness/species densities on reaches downstream of culverts.

Table 17: Results from pairwise two-tailed wilcoxon signed ranks tests on stream habitat variables for: (a) richness group 1 sites and (b) richness group 2 sites

Table 18: Results from pairwise two-tailed wilcoxon signed ranks tests on stream habitat variables for: (a) blacknose dace density group 1 sites and (b) blacknose dace density group 2 sites.

Table 19: Results from linear regression between pairwise richness differences and the listed habitat variables.

Table 20: Results from linear regression between pairwise blacknose dace (Rhinichthys atratulus) density differences and the listed habitat variables.... 
Table 21: Results from Kolmogorov-Smirnov tests comparing upstream and downstream cumulative proportional curves for the following combinations of variables.

Figures

page

Figure 20: Map of the chapter 3 study area.

Figure 21: Sampling scheme for water quality, habitat, and fish abundance data sampling at culverts.

Figure 22: a) Cumulative species count for both above and below reaches plotted against log-transformed basin area $\left(\mathrm{km}^{2}\right)$. Cumulative proportional species count for both above and below reaches plotted against: b) basin area $\left(\mathrm{km}^{2}\right)$ and c) slope (\%) for all abovebelow sites.

Figure 23: Pairwise differences (downstream - upstream) in a) species richness, b) mottled sculpin density, c) brook trout density, d) blacknose dace density, e) creek chub density, f) white sucker density, and g) rosyside dace density plotted against basin area for all above-below culvert sites.

Figure 24: a) Cumulative blacknose dace (Rhynichthys atratulus) density plotted separately for above and below reaches against basin area $\left(\mathrm{km}^{2}\right)$. Cumulative proportional blacknose dace density plotted for both above and below reaches against: b) basin area $\left(\mathrm{km}^{2}\right)$ and c) slope (\%).....

Figure 25: a) Cumulative mottled sculpin (Cottus bairdi) density plotted against basin area $\left(\mathrm{km}^{2}\right)$ for both above and below reaches. Cumulative proportional mottled sculpin density plotted separately for above and below reaches against: b) basin area $\left(\mathrm{km}^{2}\right)$ and c) slope (\%)

Figure 26: a) Cumulative brook trout (Salvelinus fontinalis) density plotted separately for above and below reaches against basin area $\left(\mathrm{km}^{2}\right)$. Cumulative proportional brook trout density plotted separately for above and below reaches against: b) basin area $\left(\mathrm{km}^{2}\right)$ and c) slope (\%)

Figure 27: Observed versus expected values, given downstream models, for the following fish community variables: a) species richness, b) mottled sculpin density, c) brook trout density, d) blacknose dace density, e) creek chub density, f) white sucker density, and g) rosyside dace density..

Figure 28: Species richness differences divided into three culvert effect groups

Figure 29: Pairwise differences (DS-US) in blacknose dace (Rhinichthys atratulus) density plotted against BA divided into culvert effect and no culvert effect sites....

Figure 30: Pairwise richness differences plotted against stream-distance from the culvert to the nearest mainstem point for all above-below sites. 
Figure 31: Pairwise richness differences plotted against the coefficient of variation of average current velocity for all above-below sites.

Figure 32: Pairwise differences in blacknose dace density plotted against median substrate $\overline{\text { size }\left(\mathrm{D}_{50}\right)}$ for all above-below sites................................................. 142

Figure 33: Blacknose dace density difference (downstream - upstream) in individuals per $100 \mathrm{~m}^{2}$ plotted against median substrate size $\left(\mathrm{D}_{50}\right)$ in $\mathrm{mm}$ for all above-below sites after the removal of the outlier site.

Figure 34: Percent of culvert sites where a given species was present upstream of the culvert versus the upstream extent of the species core range (Freund 2004), in basin area $\left(\mathrm{km}^{2}\right)$ 


\section{Acknowledgements}

I thank the following individuals for assistance in the field: Erica Browne, Jason Clingerman, Seth Davis, Jared Gregory, Lee Haggerty, Zachary Golightly, Tony Grubb, Tom “Live by the Swoosh” Hardman, Zina Hense, Karen Kish, Patrick “Stupid” Kish, Ross Kite, Seth Lemley, Zachary Liller, Roy Martin, Michael Nicholas, Logan Wamsley, Ryan “Tex” Ward, and Joshua "Hillbilly” White. I especially thank the culvert crew of 2003 for teaching me the following life lessons: to truly understand and appreciate the versatility of hot dogs; that you can actually get a tan at night if you pile enough hemlock onto your campfire; and the correct spelling of the word "cone." I also thank the field crew of 2004 for teaching me the following life lessons: always carry a pack of gum and a roll of duct tape in the field at all times; Tom Hardman, a block of wood, and a hatchet equal world class entertainment; and that donuts and instant coffee are the key to complete contentment.

I also thank my committee for their advice and support. I especially thank J. Todd Petty, my advisor, for this research opportunity, the chance to further my education, and for being extremely positive and encouraging. I thank Mike Strager for GIS help. I thank Jen BarkerFulton, who keeps the Petty lab sticking together. I thank the West Virginia Division of Highways and the West Virginia University Division of Forestry for funding and support to conduct this research.

Finally, I express endless gratitude to my friends and family for their encouragement and support and believing in me when I wasn’t sure I could do it. I thank my mother for putting up with countless stressed-out phone calls and her uncanny ability to know exactly what to say. I thank my father for always pushing me to keep going and for being a good friend. I thank my sister for supporting me through hard times. I thank Nicholas Heltzel for being my best friend all 
the way from Kyrgyzstan. And finally, I thank Erica Browne for never leaving my side through the thick and the thin. 


\section{Executive Summary}

As fish passage barriers, culverts can isolate critical habitats and hold the potential to severely impact fish populations. Streams are particularly vulnerable to fragmentation and there is growing concern that culverts may alter stream ecosystems by disrupting connectivity within drainage networks. The improvement or replacement of barrier culverts has the potential to restore access to critical habitats for various stream-dwelling organisms. There is a need for further inventory of culverts in West Virginia, as well as a general need for further research into the impacts of culverts on stream fish populations and assemblages. Our research was divided into five main objectives. First, we conducted an inventory of culvert road crossings on state roads located within a portion of the upper Cheat River basin, West Virginia, crossing high quality streams to summarize culvert barrier conditions. The second objective was to develop an ArcGIS model to quantify the proportion of stream length and potential brook trout recruitment area that was isolated by barrier culverts on state roads within the study area. The third objective was to present a prioritized list of stream restoration opportunities at culvert road crossings to the West Virginia Division of Highways. Fourth, we investigated culvert-related impacts on fish assemblages within an overlapping portion of the upper basin to assess whether culverts impact fish diversity or population densities. Our final objective was to identify whether culvert-related impacts were related to any physical stream characteristics (e.g. channel slope or basin area).

We surveyed 120 state road culverts within a portion of the upper Cheat River basin, West Virginia during the summer of 2003. At each culvert we measured a number of structural variables, including residual inlet and outlet depth, inlet width-average active channel width ratio, outlet hang height, and culvert slope. We also noted whether a continuous layer of streambed substrate was present and whether baffles or weirs were placed within the culvert for fish passage. We then used a fish passage evaluation filter from Love and Taylor (2003) to 
characterize the relative passability of each culvert: completely impassable, partially impassable, or completely passable. Finally, we built an ArcGIS model to quantify the length of stream and weighted potential brook trout recruitment area (WPRA) isolated by each culvert. We then prioritized each culvert based upon its passage rating and the amount of isolated WPRA.

During the summer of 2004, we sampled fish assemblages and several habitat variables within $150 \mathrm{~m}$ stream reaches both above and below 24 culvert road crossings within small streams of the upper Cheat River Basin. We used pairwise Wilcoxon Signed Ranks tests as well as stepwise multiple regression analysis to test whether species richness or species densities were different upstream of culverts compared to downstream and whether differences could be attributed to population isolation upstream of culverts.

Overall, $69 \%$ of culverts were categorized as completely impassable, $28 \%$ were partially impassable, and $3 \%$ were completely passable. Culvert slope and outlet hang were the main determinants of impassable culverts and the likelihood that a culvert was impassable increased with increasing stream channel slope. We determined that $144 \mathrm{~km}$ of stream (17\% of study area) and $130 \mathrm{~km}$ of WPRA (23\% of study area) were isolated by impassable culverts. We found that Shavers Fork section of the upper Cheat basin had the highest extent and intensity of habitat isolation. We found that mean species richness was significantly lower upstream of culverts (2.0) than downstream (2.6) $(\mathrm{p}=0.014)$ and no richness effect was observed on any stream draining over $3.5 \mathrm{~km}^{2}$. We found that blacknose dace (Rhinichthys atratulus) densities were significantly lower upstream of culverts (8.2 individuals/100 m) than downstream (12.1 individuals $/ 100 \mathrm{~m})(\mathrm{p}=0.011)$. The difference in richness could be attributed to either the isolation of populations above culverts or a combined isolation-channel gradient effect where culvert isolation had more impact where stream slopes are higher upstream of the culvert. Differences in blacknose dace densities could be attributed to a culvert-isolation effect only. 
Moreover, we found that pairwise differences in richness (downstream-upstream) were positively correlated with stream distance of the culvert from the mainstem (nearest point draining $15 \mathrm{~km}^{2}$ ) and negatively correlated with longitudinal variation in average flow velocity. Finally, we found that culvert effects are more pronounced on species whose core ranges are limited to larger streams compared to species that range into smaller streams.

The upper Cheat River basin is characterized by a high proportion of barrier culverts that cause discontinuities within the stream network. This problem has significant negative impacts on stream ecosystems by isolating small streams from larger mainstem rivers. These findings underscore the importance and vulnerability of headwater stream ecosystems and show that culvert isolation, among other impacts, has negatively impacted fish assemblages within the basin. However, because culvert-related impacts are most pronounced on ubiquitous species (i.e. blacknose dace) and large stream species but greatest on small, steep, streams, we feel that culvert-related restoration efforts will not have as much overall benefit to fish assemblages in this basin as the remediation of more extensive problems, such as acid deposition. Additionally, these results show that fish passage standards should consider whole communities. 


\section{Chapter 1}

\section{Literature Review and Objectives.}

\section{Abstract}

Gerking (1959) proposed a theory now known as the 'restricted movement paradigm' that states that adult stream-resident fish are sedentary. However, much of the research that has supported this paradigm has been prone to bias against the detection of movement, and we know that fish movement is more common than previously thought. Fish movement is considered to be an adaptive response to changing habitat needs and conditions. Movement is important for the location of habitats at the watershed scale and the maintenance of genetic diversity. Fish move in response to variable food availability or to locate spawning habitat, thermal refuge, overwintering habitat, or nursery habitat. There are five common conditions at culverts that create movement barriers: excess drop at the culvert outlet, high velocity within the culvert barrel, inadequate depth within the barrel, turbulence within the culvert, and debris and sediment accumulation at the culvert inlet or internally. As passage barriers, culverts can isolate critical habitats and hold the potential to severely impact fish populations. Warren and Pardew (1998) found that overall fish movement was an order of magnitude lower through culverts than through other crossings or natural reaches. Additionally, numbers of species that traversed crossings and movement within three of four dominant fish families (Centrarchidae, Cyprinidae, and Fundulidae) were reduced at culverts relative to fords, open-box crossings, and natural reaches (Warren and Pardew 1998). The traditional view was that culverts primarily caused problems with anadromous fish populations. A majority of fish passage research and culvert inventories have been conducted in western states with large anadromous fish populations. There is a need for further inventory of culverts in West Virginia, as well as a general need for further research 
into the impacts of culverts on stream fish populations and assemblages. The goal of this study was to develop culvert replacement prioritization criteria for the West Virginia Division of Highways as well as to investigate the impacts of culvert crossings on stream fish communities within the upper Cheat River basin, West Virginia.

\section{Literature Review}

Gerking (1959) proposed a theory about the restricted movement of stream fishes that has been considered a paradigm in stream fish biology and is referred to as the 'restricted movement paradigm (RMP).' This theory stated that adult fish in streams are sedentary and spend most of their lives within short reaches of stream, or within a restricted home range (Rodriguez 2002). Gerking (1953) defined the term 'home range’ as the area over which an animal normally travels. The RMP guided much of the research into the dynamics of stream fish populations for the next 30 years and many studies in the past have supported it (Gowan et al. 1994). However, many of the studies that have supported the RMP or have noted the existence of only a small mobile population component in the past have employed methods that may be seriously biased against detecting fish movement. These studies have relied on the recapture of marked fish from the same areas in which they were released (Gowan et al. 1994; Gowan and Fausch 1996). Most of these analyses were based solely on the portion of originally marked fish that were recaptured within the study area or within a close vicinity, and this was often times well under 50 percent of the originally marked fish (e.g. Stefanich 1952; Gerking 1953; Shetter 1968; Moore et al. 1985; Nakamura et al. 2002). Using these methods analyses did not include the large proportion of fish not recaptured that could have moved very long distances outside of the study area. In most cases, this proportion was too large to be explained simply by mortality.

For example, Moore et al. (1985) found that in one stream in the Great Smokey Mountains National Park 56.2 \% of recaptured adult stream-resident brook trout (Salvelinus 
fontinalis) were located in the same $300 \mathrm{~m}$ sections in which they were released and $83.3 \%$ either remained home or moved only one section upstream or downstream. Preliminarily, this would indicate a relatively sedentary population of brook trout, however, of the initial 1,702 trout originally marked only $24.8 \%$ were actually ever recaptured (Moore et al. 1985). Nothing was, nor could have been concluded about the $75.2 \%$ of trout that were not recaptured. Similarly, Nakamura et al. (2002) studied the residency and movement of stream-dwelling Japanese charr (Salvelinus leucomaenis) in a central Japanese stream from 1986 to 1989. The researchers in this study found that $31.3-58.3 \%$ of the fish recaptured were located in pools where they were originally captured and concluded that the results indicated a large sedentary proportion of the population. However, in this study only 697 of 2,103 fish were ever recaptured and, again, those fish which were not recaptured (a majority) were not considered. Based upon this sampling scheme, if there are fish that do display long-distance movements they are much less likely to be recaptured because they are more likely to have moved outside of sampled sections of stream than sedentary fish. Any study using this sampling scheme has the potential to bias results against movement.

On the contrary, some recent literature on stream resident salmonid movement has pointed out this bias and has suggested the re-evaluation of this paradigm (Gowan and Fausch 1996) or that the RMP is incomplete (Rodriguez 2002) or even lost (Gowan et al. 1994). Researchers in recent years have found that stream-resident fish movement may be much more common than previously thought. Many researchers have noted a pattern of movement by resident stream fish (both cold- and warmwater species) that suggests that there is a large static fraction that does not leave a restricted home range and a small mobile fraction of individuals that make up a population (Stefanich 1952; Funk 1955; Gerking 1959; Stott 1967; Flick and Webster 1975; Solomon and Templeton 1976; Hesthagen 1988; Heggenes et al. 1991). Burrell 
et al. (2000) observed upstream spawning migrations by stream-resident brown trout (Salmo trutta) in the Chattanooga River during a two-week period in November 1996. The maximum upstream movement during spawning was $7.65 \mathrm{~km}$, which indicated the ability of the brown trout in this river to move long distances. Gowan and Fausch (1996) found that brook trout in two high-elevation Colorado streams were highly mobile with movement most common in the upstream direction during summer, and about equal upstream and downstream between summers. These researchers found that the highest rates of movement occurred during and just after runoff and before spawning. They reported that long-range movements were relatively common and suggested that movement may be more widespread than currently recognized in resident stream salmonids. Similarly, Riley et al. (1992) studied the movement of brook trout in four small streams in Northern Colorado and also found that a large proportion of the brook trout sampled were mobile with movement occurring predominantly in the upstream direction. Upstream moving fish were also significantly larger than downstream migrants suggesting the upstream movement of larger adult fish to spawning areas. These researchers suggested that the high degree of movement that was observed could have been an adaptive response by brook trout to the heterogeneous nature of small mountain streams (Riley et al. 1992). Adams et al. (2000) also found that upstream movements were more common than downstream movements for brook trout during the summer. They found that marked brook trout ascended stream slopes up to 13\% for more than 67 meters (Adams et al. 2000).

Because brown trout are not native to North America and brook trout are not native to the Rocky Mountains region, a legitimate argument is that the movements observed in the previously mentioned studies might be due to the lack of adaptation by these species to the unique dynamics of habitats and flows in these systems. However, native stream salmonids are also known to display substantial movement (Fausch and Young 1995). Petty et al. (2005) studied native brook 
trout population dynamics in Second Fork, a somewhat acid impacted and physically heterogeneous 3rd order tributary to the Upper Shavers Fork of the Cheat River, West Virginia. These researchers found that nearly $80 \%$ of native brook trout spawning occurred in tributaries with a basin area of less than $3 \mathrm{~km}^{2}$ and that spawning intensity was basin-area dependent. Furthermore, despite spawning intensity being basin-area dependent, the distribution of large spawning adults in subsequent seasons was not associated with spawning intensity. These results were indicative of highly mobile large adults that shifted their distribution seasonally in response to shifting habitat requirements and local habitat suitability. Similarly, Hunt (1974) recorded the upstream movement of adult brook trout to spawning grounds in the autumn in Lawrence Creek, Wisconsin.

Theories of fish dispersal hold that movement is adaptive, conferring advantages to individuals in terms of their lifetime fitness (Northcote 1978; Gross 1987). If the benefits of moving to one or more new habitats outweigh the energetic costs of movement and the risk of predation, life history types that move should be favored (Gross et al. 1988). Furthermore, because streams are linear systems in which habitat is inherently patchy in space (Pringle et al. 1988; Scarsbrook and Townsend 1993) and dynamic through time (Poff and Ward 1989), stream fishes often must move to find habitats needed to maximize fitness (Fausch and Young 1995). In streams, habitat patches may be distributed at the watershed scale and the importance and distribution of habitat patches changes over time due to changes in the needs of fish and temporal variation in the physical characteristics of the stream. Consequently, fish often move long distances at the watershed scale to locate suitable habitats. For example, brook trout have been shown to select spawning sites where upwelling groundwater occurs through stream bed substrate and substratum particle size and compactness allows redd construction (Bridges 1958; Power 1980). These fish may have to move different directions and distances to locate 
groundwater influenced spawning sites (Power et al. 1999).

Although the location of suitable spawning habitat is the most obvious motivation for stream-resident fish movement (Kahler and Quinn 1998) there are other factors that influence movement. Fish may move in response to changing water temperatures (e.g. Kaeding 1996) or stream discharge, in response to variable food availability (e.g. Petty and Grossman 2004), to locate refuge from predators (e.g. Harvey 1991), or in search of habitat suitable for the completion of certain life-history stages (e.g. nursery habitat for juveniles, Johnston 1997).

Both Clapp et al. (1990) and Meyers et al. (1992) found that habitats used by brown trout in the winter were not suitable during the summer due to high water temperatures. Kaeding (1996) studied the use of coolwater tributaries by brown trout and rainbow trout (Oncorhynchus mykiss) in the Firehole River, a geothermally heated stream in Yellowstone National Park, Wyoming. The Firehole receives substantial amounts of geothermally heated, mineralized water from hot springs and geysers. In the summer, both species moved to coolwater tributaries and mainstem areas upstream from the major sources of geothermal effluents and used these areas as refuges from elevated water temperatures (Kaeding 1996). Several studies have noted the movement of trout to suitable overwintering sites. For example, Brown and Mackay (1995) studied the fall and winter movements of stream-resident cutthroat trout (Oncorhynchus clarki) in the Ram River, Alberta. These researchers found that these fish moved out of summer habitats in mid-September, and many made a dramatic shift in habitat use from summer to winter that was associated with anchor ice formation. When the fish were excluded from fall habitats by anchor ice, they moved to overwintering areas less likely to be influenced by frazil and anchor ice: deep pools with ice cover or areas where water temperatures were higher than the rest of the stream because of springs or upwelling warm groundwater (Brown and Mackay 1995). Bjornn and Mallet (1964) noted a pattern of downstream movement in the fall and winter 
following upstream movement to spawning areas in the spring for stream-resident cutthroat trout. Several studies have noted the downstream movement of brook trout during the winter from fall habitats to reach overwintering areas. These areas include lower gradient reaches with dense cover or surface ice, deeper pools, and slower current velocities (Cooper 1953; Logan 1963; Hunt 1974; Chisholm et al. 1987). Petty and Grossman (2004) found that juvenile mottled sculpin (Cottus bairdi) in Shope Fork, North Carolina, exhibited higher growth rates among groups of 'movers' (individuals that moved more than $2 \mathrm{~m}$ between seasonal captures) than among 'stayers' (individuals that moved less than $2 \mathrm{~m}$ ). This result indicated that 'movers' were better able to garner scarce resources by moving.

Movement is important, especially in physically heterogeneous habitats, to many streamresident fish populations in order to locate thermal refugia and refuge from predators, locate suitable spawning and foraging habitats, recolonize decimated stream reaches, maintain genetic diversity between subpopulations, and locate habitats suitable for the completion of various lifehistory stages. Additionally, fish movement and influences on movement (e.g. population size structure, stream flow, distribution of critical habitats) hold important consequences for population regulation and dynamics. For example, Petty and Grossman (2004) found that juvenile mottled sculpin had faster growth rates when movement rates were high, but exhibit less movement when large adult densities are high. Additionally, sedentary adults exhibited higher growth rates than mobile adults. So when adult densities were low, juveniles moved more and grew at faster rates and adults moved less and also grew faster, probably facilitating rapid population growth. When adult densities were high, the opposite effect probably took place, facilitating population decline (Petty and Grossman 2004). It is clear that barriers to movement can have drastic effects on stream-resident fish populations, communities, and the ecosystems to which they belong. There are many structures, both natural and anthropogenic, that can act as 
fish passage barriers [e.g. natural waterfalls, beaver (Castor canadensis) dams, man-made dams, road crossings, etc] and this list includes culvert road crossings.

The primary literature concerning culverts as barriers to stream resident fish movement is relatively limited, however there have been several studies (e.g. Belford and Gould 1989; Thompson and Rahel 1998; Warren and Pardew 1998; Wellman et al. 2000; Gibson et al. 2005). Warren and Pardew (1998) used mark-recapture techniques to examine the effects of four types of road crossings (culvert, slab, open-box, and ford) on fish movement in small streams of the Ouachita Mountains. These researchers found that ford and open-box crossings showed little difference from natural reaches in overall movement of fishes. However, overall fish movement was an order of magnitude lower through culverts than through other crossings or natural reaches. The numbers of species that traversed crossings and movement within three dominant fish families (Centrarchidae, Cyprinidae, and Fundulidae) were also reduced at culverts relative to ford and open-box crossings and natural reaches. They found that water velocity at crossings was inversely related to fish movement and culvert crossings consistently had the highest velocities (Warren and Pardew 1998). Thompson and Rahel (1998) evaluated the effectiveness of two gabion and two culvert barriers in preventing the upstream movement of non-native brook trout which were competing with and encroaching upon native Colorado River cutthroat trout (Oncorhynchus clarki pleuriticus) in four small Rocky Mountain streams in Colorado. Culverts in this study were found to be effective barriers as only one brook trout out of 118 that were marked and released downstream of culverts was subsequently found upstream. The researchers postulated that this single trout was probably transported by an angler (Thompson and Rahel 1998). Belford and Gould (1989) studied culvert water velocities critical to the passage of four species of non-anadromous trout (rainbow trout, brown trout, cutthroat trout, and brook trout) through six highway culverts 45-93 m in length. Because of the similarity of the strenuous 
passage relations among species, they concluded that the spawning rainbow trout criterion could be used as the general criterion for passage of all species studied concluded that these trout could swim distances of $10,30,50,70$, and 90 m through culverts with mean bottom velocities up to 0.96, 0.80, 0.74, 0.70, $0.67 \mathrm{~m} / \mathrm{s}$, respectively (Belford and Gould 1989).

It is obvious from the literature that barrier culverts can create problems for upstream moving fish. Moreover, culverts may not need to be complete barriers to drastically affect fish populations. Even if stronger adult fish can obtain passage, juveniles might not be able to. Passage may only be possible at high or low flows or only physically possible for stronger individuals (USFS 2002). Additionally, pre-spawn fish may deplete vital energy stores critical to spawning while attempting to successfully traverse a barrier or delay spawning later than optimal for egg survival (USFS 2002). The overall result may be the under-utilization of available habitat by all or a portion of the population, the isolation of critical seasonal habitats (i.e. overwintering habitats or thermal refuge during the summer), or the isolation of habitats critical to certain life-stages (i.e. nursery habitat for juvenile fish or spawning habitat for adult fish). These results have the potential to negatively impact population size and range. Moreover, the failure to provide fish passage at road crossings can reduce the genetic diversity of isolated resident fish populations or cause their complete loss after catastrophic events (USFS 2002). There are five common conditions at culverts that create migration barriers: excess drop at the culvert outlet, high water velocity within the culvert barrel, inadequate water depth within the culvert barrel, turbulence within the culvert, and debris and sediment accumulation at the culvert inlet or internally. The interior surface of a culvert is usually designed to optimize water passage and it does not have the necessary roughness and complexity needed to slow down the flow. Instead, culverts tend to concentrate and dissipate energy in the form of increased velocity. Turbulence or downstream channel scour are the most prevalent blockages at culverts (Bates 
2003).

The impacts of culverts could possibly extend further than fish. Culverts also can impact the ecosystems to which fish belong. For example, the parasitic larval stage (glochidia) of freshwater mussels depends upon the movement of host organisms, fish, to disperse upstream. Any culvert blocking the upstream passage of fish hosts also will prevent mussels from colonizing habitat within their ranges (Vaughan 2002). Additionally, fish are keystone predators in most small streams and probably act to regulate populations of several species of prey. The exclusion of fish predators from these ecosystems could potentially have drastic top-down effects on entire food webs, releasing predation pressure from some members and allowing them to unnaturally thrive.

The traditional view was that culverts primarily caused problems with anadromous fish populations. So a majority of fish passage research and culvert inventories have been conducted in western states, such as Washington and Oregon, with large anadromous fish populations (Baggett et al. 2001). Evidence shows, in most states, that a large proportion of culverts act as passage barriers and these culverts probably have a large impact on mobile fish populations. Furthermore, there is growing evidence that we should be concerned with culvert effects on stream-resident fish in addition to anadromous fish (e.g. Warren and Pardew 1998). Clearly there is a need for further inventory and barrier assessment of culverts in West Virginia, as well as a general need for further research into the effects of culverts on stream-resident fish populations and communities.

\section{Goals and Objectives}

The two research goals of this study were to develop ranking criteria for the West Virginia Division of Highways for use as a prioritization tool for stream restoration sites at culvert crossings on state roads and to investigate the impacts of culvert crossings on stream fish 
assemblages within the upper Cheat River basin of West Virginia. These two goals are separated into two separate chapters.

The first objective within the first research goal (chapter 1) was to conduct an inventory of culvert road crossings on state roads located within a portion of the upper Cheat River basin, West Virginia, crossing high quality streams to summarize culvert barrier conditions. The second objective was to develop an ArcGIS model to quantify the proportion of stream length and potential brook trout recruitment area that was isolated by barrier culverts on state roads within the study area. And the final objective was to present a prioritized list of stream restoration opportunities at culvert road crossings to the West Virginia Division of Highways. This list was prioritized by the amount of potential brook trout recruitment area isolated by barrier culverts.

The first objective of the second research goal (chapter 3) was to investigate culvertrelated impacts on fish assemblages within a portion of the upper Cheat River basin, West Virginia to assess whether culverts impact fish diversity or population densities. A secondary objective was to identify whether culvert-related impacts were related to any physical stream characteristics (e.g. channel slope, basin area, or median substrate size).

\section{Literature Cited}

Adams, S. B., C. A. Frissell, and B. E. Rieman. 2000. Movements of nonnative brook trout in relation to stream channel slope. Transactions of the American Fisheries Society 129: 623-638.

Baggett, A., E. Chiao, and T. Harton. 2001. Habitat conservation plan for the upper Etowah River watershed: Road Crossings-Effects and recommendations. Unpublished Manuscript. 33 pp. Available at http://www.rivercenter.uga.edu/education/etowah/ documents/pdf/hcp_bridges.pdf

Bates, K. 2003. Design of road culverts for fish passage. Washington Department of Fish and Wildlife Publication. 110 pp. Available at www.wa.gov/wdfw/hab/ engineer/cm/toc.htm. 
Belford, D. A., and W. R. Gould. 1989. An evaluation of trout passage through six highway culverts in Montana. North American Journal of Fisheries Management 9: 437-445.

Bjornn, T. C., and J. Mallet. 1964. Movements of planted and wild trout in an Idaho river system. Transactions of the American Fisheries Society 93: 70-76.

Bridges, C. M. 1958. A compendium of the life history and ecology of the eastern brook trout. Massachusetts Division of Fisheries and Game. Fisheries Bulletin 23: 1-37.

Brown, R. S., and W. C. Mackay. 1995. Fall and Winter movements of and habitat use by cutthroat trout in the Ram River, Alberta. Transactions of the American Fisheries Society 124: 873-885.

Burrell, K. H., J. J. Isely, D. B. Bunnell Jr., D. H. Van Lear, C. A. Dolloff. 2000. Seasonal movement of brown trout in a southern Appalachian river. Transactions of the American Fisheries Society 129: 1373-1379.

Chisholm, I. M., W. A. Hubert, and T. A. Wesche. 1987. Winter stream conditions and use of habitat by brook trout in high-elevation Wyoming streams. Transactions of the American Fisheries Society 116: 176-184.

Clapp, D. F., R. D. Clark, Jr., and J. S. Diana. 1990. Range, activity, and habitat of large freeranging brown trout in a Michigan stream. Transactions of the American Fisheries Society 119: 1022-1034.

Cooper, E. L. 1953. Periodicity of growth and change of condition of brook trout (Salvelinus fontinalis) in three Michigan trout streams. Copeia 1953: 107-114.

Fausch, K. D., and M. K. Young. 1995. Evolutionary significant units and movement of resident stream fishes: a cautionary tale. American Fisheries Society Symposium 17: 360-370.

Flick, W. A., and D. A. Webster. 1975. Movement, growth, and survival in a stream population of wild brook trout (Salvelinus fontinalis) during a period of removal of non-trout species. Journal of the Fisheries Research Board of Canada 32: 1359-1367.

Funk, J. L. 1955. Movement of stream fishes in Missouri. Transactions of the American Fisheries Society 85: 39-57.

Gerking, S. D. 1953. Evidence for the concepts of home range and territory in stream fishes. Ecology 34: 347-365.

Gerking, S. D. 1959. The restricted movement of fish populations. Biological Reviews of the Cambridge Philosophical Society 34: 221-242.

Gibson, R. J., R. L. Haedrich, and C. M. Wernerheim. 2005. Loss of fish habitat as a consequence of inappropriately constructed stream crossings. Fisheries 30: 10-17. 
Gowan, C., and K. D. Fausch. 1996. Mobile brook trout in two high-elevation Colorado streams: re-evaluating the concept of restricted movement. Canadian Journal of Fisheries and Aquatic Sciences 53: 1370-1381.

Gowan, C., M. K. Young, K. D. Fausch, and S. C. Riley. 1994. Restricted movement in resident stream salmonids: a paradigm lost? Canadian Journal of Fisheries and Aquatic Sciences 51: 2626-2637.

Gross, M. R. 1987. Evolution of diadromy in fishes. American Fisheries Society Symposium 1: 14-25.

Gross, M. R., R. M. Coleman, and R. M. McDowall. 1988. Aquatic productivity and the evolution of diadromous fish migration. Science 239: 1291-1293.

Harvey, B.C. 1991. Interactions among stream fishes: predator-induced habitat shifts and larval survival. Oecologia 87: 29-36.

Heggenes, J., T. G. Northcote, and A. Peter. 1991. Spatial stability of cutthroat trout (Onchorhynchus clarki) in a small, coastal stream. Canadian Journal of Fisheries and Aquatic Sciences 48: 757-762.

Hesthagen, T. 1988. Movements of brown trout, Salmo trutta, and juvenile atlantic salmon, Salmo salar, in a coastal stream in Northern Norway. Journal of Fish Biology 32: 639653.

Hunt, R. L. 1974. Annual production by brook trout in Lawrence Creek during eleven successive years. Wisconsin Department of Natural Resources. Technical Bulletin 82. 28 pp.

Johnston, T.A. 1997. Downstream movements of young-of-the-year fishes in Catamaran Brook and the Little Southwest Miramichi River, New Brunswick. Journal of Fish Biology 51: 1047-1062.

Kaeding, L. R. 1996. Summer use of coolwater tributaries of a geothermally heated stream by rainbow trout and brown Trout, Oncorhynchus mykiss and Salmo trutta. American Midland Naturalist 135: 283-292.

Kahler, T. H., and T. P. Quinn. 1998. Juvenile and resident salmonid movement and passage through culverts. Final Research Report to the Washington State Transportation Center: 38 pp.

Logan, S. M. 1963. Winter observations on bottom organisms and trout in Bridger Creek, Montana. Transactions of the American Fisheries Society 92: 140-145.

Meyers, L. S., T. F. Thuemler, and G. W. Kornley. 1992. Seasonal movements of brown trout in Northeast Wisconsin. North American Journal of Fisheries Management 12: 433-441. 
Moore, S. E., G. L. Larson, and B. L. Ridley. 1985. Dispersal of brook trout in rehabilitated streams in Great Smokey Mountains National Park. Journal of the Tennessee Academy of Science 60: 1-4.

Nakamura, T., T. Maruyama, and S. Watanabe. 2002. Residency and movement of stream dwelling japanese charr, Salvelinus leucomaenis, in a Japanese mountain stream. Ecology of Freshwater Fish 11: 150-157.

Northcote, T. G. 1978. Migratory strategies and production in freshwater fishes. Pages 326-359 in S. D. Gerking, editor. Ecology of Freshwater Fish Production. Blackwell Scientific Publications, Oxford, UK.

Petty, J.T., and G.D. Grossman. 2004. Restricted movement by mottled sculpin (Pisces:Cottidae) in a southern Appalachian stream. Freshwater Biology 49: 631-645.

Petty, J.T., P.A. Lamothe, and P.M. Mazik. 2005. Spatial and seasonal dynamics of brook trout populations in a Central Appalachian watershed. Transactions of the American Fisheries Society 134: 572-587.

Power, G. 1980. The Brook Charr, Salvelinus fontinalis. Pages 141-203. in E. K. Balon, editor. Charrs: salmonid fishes of the genus Salvelinus. Dr. W. Junk bv Publishers, The Hague, The Netherlands.

Power, G., R. S. Brown, and J. G. Imhof. 1999. Groundwater and fish-insights from northern North America. Hydrological Processes 13: 401-422.

Poff, N. L., and J. V. Ward. 1989. Implications of stream-flow variability and predictability for lotic community structure: a regional analysis of streamflow patterns. Canadian Journal of Fisheries and Aquatic Sciences 46: 1805-1818.

Pringle, C. M., R. J. Naiman, G. Bretschko, J. R. Karr, M. W. Oswood, J. R.Webster, R. L. Welcomme, and M. J. Winterbourn. 1988. Patch dynamics in lotic systems: the stream as a mosaic. Journal of the North American Benthological Society 7: 503-524.

Riley, S. C., K. D. Fausch, and C. Gowan. 1992. Movement of brook trout (Salvelinus fontinalis) in four small subalpine streams in northern Colorado. Ecology of Freshwater Fish 1: 112122.

Rodriguez, M. A. 2002. Restricted movement in stream fish: the paradigm is incomplete, not lost. Ecology 83: 1-13.

Scarsbrook, M. R., and C. R. Townsend. 1993. Stream community structure in relation to spatial and temporal variation: a habitat template study of two contrasting New Zealand streams. Freshwater Biology 29: 395-410.

Shetter, D. S. 1968. Observations on movements of wild trout in two Michigan stream drainages. Transactions of the American Fisheries Society 97: 472-480. 
Solomon, D. J., and R. G. Templeton. 1976. Movements of brown trout, Salmo trutta L., in a chalk stream. Journal of Fish Biology 9: 411-423.

Stefanich, F. A. 1952. The population and movement of fish in Prickley Pear Creek, Montana. Transactions of the American Fisheries Society 81: 260-274.

Stott, B. 1967. The movements and population densities of roach (Rutilus rutilus, L.) and gudgeon (Gibio gobio, L.) in the River Mole. Journal of Animal Ecology 36: 407-423.

Thompson, P. D, and F. J. Rahel. 1998. Evaluation of artificial barriers in small Rocky Mountain streams for preventing the upstream movement of brook trout. North American Journal of Fisheries Management 18: 206-210.

USFS (United States Forest Service). 2002. A summary of technical considerations to minimize the blockage of fish at culverts on the national forests of Alaska. Supplement to USFS briefing paper titled “Fish Passage on Alaska's National Forests.” USFS, Alaska Region. $7 p p$.

Vaughan, D. M. 2002. Potential impact of road-stream crossings (culverts) on the upstream passage of aquatic macroinvertebrates. Report submitted to the U.S. Forest Service, San Dimas Technology and Development Center. 15 pp.

Warren, Jr., M. L., and M. G. Pardew. 1998. Road crossings as barriers to small-stream fish movement. Transactions of the American Fisheries Society 127: 637-644.

Wellman, J. C., D. L. Combs, and S. B. Cook. 2000. Long-term impacts of bridge and culvert construction or replacement on fish communities and sediment characteristics of streams. Journal of Freshwater Ecology 15: 317-327. 


\title{
Chapter 2
}

\section{Survey and Prioritization of Fish Passage Restoration Opportunities at State- Owned Culvert Road Crossings in the Upper Cheat River Basin, West \\ Virginia.}

\begin{abstract}
Streams are heterogeneous ecosystems and fishes often need to move to locate habitats at the watershed scale. Consequently, streams are particularly vulnerable to fragmentation and there is growing concern that culverts and other road crossings may alter stream ecosystems by disrupting connectivity within drainage networks. The improvement or replacement of barrier culverts has the potential to restore access to critical habitats for various stream-dwelling organisms. However, before such a management action is taken, it is necessary to inventory potential culvert barriers and develop a system of prioritization. We surveyed 120 state road culverts within a portion of the upper Cheat River basin, West Virginia during the summer of
\end{abstract} 2003. At each culvert we measured a number of structural variables, including residual inlet and outlet depth, inlet width-average active channel width ratio, outlet hang height, and culvert slope. We also noted whether a continuous layer of streambed substrate was present and whether baffles or weirs were placed within the culvert for fish passage. We then used a fish passage evaluation filter from Love and Taylor (2003) to characterize the relative passability of each culvert: completely impassable, partially impassable, or completely passable. Finally, we built an ArcGIS model to quantify the length of stream and weighted potential brook trout recruitment area (WPRA) isolated by each culvert. We then prioritized each culvert based upon its passage rating and the amount of isolated WPRA. We observed the following characteristics at survey culverts: $93 \%$ of culverts did not have a continuous layer of streambed substrate, $98 \%$ did not 
have residual inlet and outlet depths of over $0.15 \mathrm{~m}, 77 \%$ had inlets that were narrower than the average active channel width, $61 \%$ were hanging at the outlet (13\% were hanging over $0.61 \mathrm{~m}$ ), and $68 \%$ had slopes of over $3 \%$. No culverts contained baffles or weirs. Overall, a majority (69 \%) of culverts were categorized as completely impassable, $28 \%$ were partially impassable, and $3 \%$ were completely passable. We determined that culvert slope and outlet hang were the main determinants of impassable culverts and that the likelihood that a culvert was impassable increased with increasing stream channel slope. We determined that $144 \mathrm{~km}$ of stream (17 \% of study area) and $130 \mathrm{~km}$ of WPRA (23 \% of study area) were isolated by impassable culverts. We found that Shavers Fork section of the upper Cheat basin had the highest extent and intensity of habitat isolation and we suggest that initial restoration efforts be concentrated in this watershed. The upper Cheat River basin is characterized by a high proportion of barrier culverts that cause discontinuities within the stream network. In addition to other factors, this problem has significant negative impacts on stream ecosystems by isolating small streams from larger mainstem rivers.

\section{Introduction}

There is growing recognition within the scientific community that aquatic ecosystems that are functionally intact and biologically complex provide valuable benefits to human society. These benefits are termed ecological services and they include flood control, transportation, recreation, purification of wastes, production of foods and other marketable goods, and habitat for plants and animals. Healthy aquatic ecosystems are more likely to sustain these services over the long-term (Baron et al. 2003). Anthropogenic activities that negatively impact an aquatic ecosystem can reduce that ecosystem’s structural integrity, ability to function naturally and ability to provide ecological services. These services are costly and often impossible to replace after degredation (Baron et al. 2003). More often than not, ecosystem values are ignored and 
long-term harm to an ecosystem is poorly quantified. This harm is often perceived to be outweighed by short-term gain when political and bureaucratic decisions are made regarding resource use (Dodds 2002). The maintenance of aquatic ecosystem integrity is a legitimate goal that must be considered among the competing demands on water resources (Baron et al. 2003).

Stream ecosystems are patchy in space (Pringle et al. 1988; Scarsbrook and Townsend 1993) and dynamic through time (Poff and Ward 1989). Consequently, stream fishes often must move to find habitats needed to maximize fitness (Fausch and Young 1995). Streams are particularly vulnerable to fragmentation, and there is growing concern about the role of culverts and other road crossings in altering habitats and disrupting stream continuity (Jackson 2003). The replacement of natural streambed substrate with an artificial crossing usually results in the loss of habitat value at some scale. Even if a culvert is not a fish migration barrier at the watershed scale, it can still impact habitat at the micro-scale by creating a discontinuity in the natural streambed substrate. In general, culvert crossings provide little habitat. This habitat loss can sometimes be partially avoided if the culvert is sufficiently embedded such that the substrate in the culvert resembles the natural streambed substrate or if open-bottom culverts or bridge crossings are installed (Jackson 2003). However, installing open bottom culverts and bridges is much more expensive than installing typical circular culverts in most cases. Additionally, while open-bottom culverts are the preferred type of culvert for allowing fish passage and providing adequate in-stream habitat, they may not always be the most advantageous from hydraulic, structural, or foundations points of view (McClellan 1970).

Common culvert types include circular, open-bottom arch, pipe arch, and box culverts. The most popular construction materials are corrugated steel pipe and concrete but other construction materials include structural steel plate, aluminum, and wood (Love and Taylor 2003). As a result of these popular designs and construction materials, culverts typically lack the 
roughness and complexity associated with stream channels and can constrict flow and increase water velocities if not properly sized or sloped. Culverts can, therefore, cause various geomorphic problems within stream channels. For example, White (2004) found that threequarters of the culverts surveyed within the upper Cheat River basin were undersized and could not convey bankfull discharge. Culverts that cannot convey bankfull discharges can cause streams to impinge the floodplain, add shear stress at the inlet, cause aggradation, and promote scouring (White 2004). Moreover, White (2004) found that culverts were not installed at the same gradient as upstream, downstream, or overall reach gradients. Generally geomorphic impacts are directly linked to the ecological impacts that culverts have on streams. Culvert crossings can constrict streamflows and water can pond upstream resulting in the accumulation of sediment above culverts as well as excess scour directly downstream due to increased water velocities inside culvert barrels. Such scouring below culverts may cause undermining or result in excess hang at culvert outlets that function as fish migration barriers (Jackson 2003). Additionally, high water velocities within the culvert barrel, inadequate depth within the culvert barrel, the deposition and aggradation of fine sediments not suitable for fish resting spots above the culvert, and debris blockages at the inlet may impede fish passage (Baggett et al. 2001).

As migration barriers, culverts can isolate potentially critical habitat to fish and various other organisms within the associated stream ecosystem, including mobile stream-resident fish such as brook trout (Salvelinus fontinalis). Through habitat fragmentation, culverts and other road crossings have the potential to alter important ecosystem functions (e.g. providing quality spawning habitat to migratory fish populations) and degrade ecosystem integrity.

Although native brook trout have suffered declines in the central and southern Appalachian mountains (Nagel 1991; Flebbe 1994; Marschall and Crowder 1996) strong populations remain within the upper Cheat River basin. However, these remnant populations are 
often isolated in small tributaries. Within this watershed adult brook trout prefer to spawn in small tributaries (basin area $<3 \mathrm{~km}^{2}$ ) regardless of their distribution in subsequent seasons, resulting in seasonal shifting of distributional patterns (Petty et al. 2005). This distributional shifting, or movement, to critical areas as habitat requirements change clearly emphasizes the importance of watershed connectivity to brook trout and their associated stream ecosystem. Several other researchers have shown that stream-resident salmonids are highly mobile (e.g. Riley et al. 1992; Gowan and Fausch 1996; Burrell et al. 2000). Kahler and Quinn (1998) concluded that resident and anadromous juveniles, as well as resident adult salmonids, are often highly mobile with upstream movement occurring in nearly all studies that were designed to detect it. It was suggested that a prudent assumption is that if salmonids are present within the system, they will likely move upstream and the timing and extent of that movement may vary on a stream by stream basis (Kahler and Quinn 1998).

Culverts can act as movement barriers to stream fish (e.g. Thompson and Rahel 1998; Warren and Pardew 1998) and therefore act as discontinuities within the stream network. As road-building continues, culverts are increasingly placed in streams causing the additive isolation of potentially critical habitat to stream fish and other organisms that could benefit from access to this habitat. Therefore, the improvement or replacement of barrier culverts with non-barrier culverts or bridges in watersheds with high road densities has the potential to restore access to critical habitats for various stream-dwelling organisms. By taking these actions a considerable amount of ecological function could be recovered within associated aquatic ecosystems.

Before such a management action is taken, however, it is necessary to inventory potential culvert barriers and develop a system of replacement prioritization. Consequently, the objectives of this research were three-fold: 1) survey all state-owned culverts within a portion of the Cheat River Basin, West Virginia, and quantify structural features as they relate to fish passage 
barriers, 2) quantify the proportion of culverts that are likely barriers to fish passage and the length of stream habitat isolated upstream of passage barriers, and 3) develop a functional measure of brook trout spawning habitat and use it to identify specific restoration priorities within the upper Cheat River basin.

\section{Study Area}

The upper Cheat River basin is located in Pocahontas, Randolph and Tucker Counties, West Virginia, and consists of all water draining to the confluence of Black Fork and Shavers Fork near the town of Parsons (Figure 1). These two rivers form the Cheat River, a major tributary to the Monongahela River. Black Fork is formed at the confluence of Dry Fork and the Blackwater River 6.4 km upstream of the Shavers Fork-Black Fork confluence. Both Dry Fork (6th order) and Shavers Fork (5th order) support cool-water fisheries and drain coldwater tributaries characterized by low overall productivity and simple biological communities.

The Dry Fork and Shavers Fork drainages were the main focus of this project. Specifically, the study area included the following streams and their tributaries that were referred to as sections. Sections were not referred to as watersheds because, in several cases, large portions of the drainage were excluded from the study due to water quality impairment or lack of roads. The study sections included lower Dry Fork (downstream of the Gandy Creek confluence and excluding Red Creek, Glady Fork, Otter Creek, and Laurel Fork), upper Dry Fork (Gandy Creek, $4^{\text {th }}$ order; and Dry Fork upstream of Gandy Creek confluence, 3rd order), and Shavers Fork. These four sections were chosen due to their abundance of relatively high quality tributaries and high road densities. It will be important to note that Dry Fork, especially in upper sections, is characterized by geology such that flow tends to go subsurface during the summer months and the stream channel turns dry in many areas. Consequently, many relatively large tributaries are ephemeral in the Dry Fork watershed. 
The upper Cheat River basin ranges in elevation from 494 to 1,476 m. Other general physical characteristics are listed in Table 1 and are divided by section. Both Randolph and Tucker Counties are characterized by humid-temperate climates. Winters are cold and snowy at high elevations and valleys also are cold and snowy but have intermittent thaws. Summers are mildly warm at high elevations and very warm with the occasional very hot day in the valleys. The average annual temperature is $9.7^{\circ} \mathrm{C}$ in Randolph County (Pyle et al. 1982) and $9.4^{\circ} \mathrm{C}$ in Tucker County (Losche and Beverage 1967). Mean annual precipitation in Randolph County is $107 \mathrm{~cm}$ and $55 \%$ of this precipitation usually falls between April and September (Pyle et al. 1982). Mean annual precipitation in Tucker County is $135 \mathrm{~cm}$ (Losche and Beverage 1967).

\section{Methods}

\section{Culvert Survey}

We first identified all road-stream intersections within the study area in ESRI ArcGIS v8.3. A digital 1:24,000 scale topographic layer, as well as linear road and 1:24,000-scale linear stream shapefiles were used for this task. We opted not to survey culverts crossing highly degraded streams [2002 West Virginia Impaired Waters and Impairments List] or culverts crossing streams draining less than $0.44 \mathrm{~km}^{2}$ (100 acres). This decision was based on the fact that restoring connectivity to these streams would likely have relatively little benefit to fish populations compared to larger streams with good water quality. We also opted not to survey culverts on private drives or forest service roads (state routes only), or culverts under busy highways that were deemed to dangerous to survey.

An exhaustive survey of 120 culverts was performed throughout the three study sections during the summer and fall of 2003 (June-November). This project was part of a broader project looking at stream stability, geomorphology, in-stream and riparian habitat, and amphibian and fish passage at road crossings (White 2004; Ward 2005). A full list of parameters surveyed at 
each culvert is given in Table 2. However, in this paper we focus only on those variables known to influence fish passage.

Culvert surveys were conducted in seven separate steps. In step one, we documented a variety of site-descriptive information at each culvert including road number, road type (e.g. paved or gravel, one-lane or two-lane), watershed (e.g. Shavers Fork, lower Dry Fork, or upper Dry Fork), stream name, USGS quagrangle, county, and global positioning system coordinates. In step two, we documented a variety of site conditions including flow level (e.g. low, isolated pools, low, moderate, high, very high), and whether there was any obvious water quality impairment (e.g. iron floculant from acid mine drainage or high levels of algae growth) or channel relocation. We additionally recorded adjacent land-use conditions (e.g. pristine, low impact, moderate impact, severe impact) and whether we observed aquatic organisms.

In step three, we measured specific aspects of each culvert, such as the diameter of the culvert barrel (m), culvert length (m), and culvert hang height at the outlet (m). We also recorded the culvert type (circular, pipe arch, or box), construction material (corrugated steel, aluminum, concrete, stone, or wood), sediment thickness (cm) at both the inlet and outlet, whether the bottom of the culvert was embedded in the streambed, and whether the culvert contained baffles or weirs for fish passage.

In step four, we measured a variety of channel dimensions including bankfull depth (m), bankfull width (m), and active channel width (ACW) (m). Bankfull and active channel widths were the mean of four measurements taken at representative riffle sections located upstream of the culvert. To calculate bankfull width, we stretched a meter tape across the channel in the riffle location where the bankfull level was easiest to identify. We then measured bankfull depth at four evenly spaced intervals across this transect and took the mean of these measurements. A variety of geologic, soils, and geomorphic data were measured and recorded in step 
five. These data were used in the geomorphic and channel stability assessment section of this project (White 2004). This step included observational data (e.g. bedrock unit, valley type, and rosgen stream classification) as well as measurements (e.g. bank scour dimension above and below the culvert and aggradation dimensions above the culvert).

In step six, we recorded a variety of information regarding in-stream habitat and riparian corridor conditions including an EPA Rapid Visual Habitat Assessment (Barbour et al. 1999) upstream and downstream of the culvert, an estimate of the percent of forested canopy cover in the riparian zone (above, below, left and right of the culvert), an estimate of the percent canopy cover of vegetation altered by the road crossing (above, below, left and right of the culvert), an estimate distance from the culvert to riparian trees or shrubs (above, below, left and right of the culvert), and whether or not the crossing appeared to be a barrier to riparian species movement (left and right of the culvert). Moreover, we noted whether there was a continuous layer of streambed substrate located within the culvert.

In step seven of each survey, we conducted a longitudinal topographic survey of reaches upstream and downstream of each culvert. Reach length was set equal to $30 \mathrm{x}$ ACW with the culvert placed at the center of the reach. These surveys were performed with a Leica Rugby 100LR laser level and a Leica Rod-Eye Pro sensor. We recorded streambed elevations (m) at the following points in this order: head of the riffle nearest the upstream end of the reach, culvert inlet elevation and water depth (m), culvert outlet elevation and water depth (m), elevation and water depth (m) at the deepest point within $2 \mathrm{~m}$ downstream of the outlet, elevation and water depth (m) at the point of maximum depth within the outlet pool, elevation and water depth (m) at the tailwater control of the outlet pool (i.e. point where the outlet pool transitions into riffle), elevation of the active channel margin at the point of tailwater control, and elevation at the head of the riffle nearest the downstream end of the reach. In addition to these elevations, elevations 
at major changes in channel slope were taken during most surveys.

\section{Culvert Classification}

After surveys were complete, data were compiled and we used the stream-resident salmonid passage protocol of Love and Taylor (2003) to estimate the relative "passability" of each surveyed culvert. We had planned, originally, to use USDA Forest Service software, FishXing, to estimate the passability. However, we found that this software rated all of our culverts impassable for even the strongest-swimming species, including culverts that were obviously not fish passage barriers. Consequently, we opted to use the passage filter from Love and Taylor (2003). Even though this filter was developed in California, we felt that it was appropriate for use in our West Virginia study because it was developed for stream-resident trout. Passage standards for stream resident trout in California are adequate for stream-resident trout in West Virginia and, if anything, are conservative due to the extremely steep nature of most of the streams in our study area. We believe that any culvert that was classified as a fish passage barrier using this filter within our study area, was classified conservatively. This protocol incorporates six criteria into a filter to classify culverts into one of three types (Figure 2). Type one culverts (also known as “green” by Love and Taylor 2003) are considered completely passable to all salmonid species (Love and Taylor 2003). Type two (“gray”) culverts are considered partially impassable. Type three ("red”) culverts are considered completely impassable. The six criteria that determine this classification include: the presence of a continuous layer of streambed substrate, residual inlet and outlet depths, inlet width-ACW ratio, outlet hang height (vertical distance from the culvert outlet elevation to the outlet pool water surface elevation), culvert slope, and the presence of baffles or weirs within the culvert for fish passage (Figure 3). 
Residual inlet and outlet depths, as well as culvert slope, were calculated from longitudinal survey data. Residual inlet depth is the difference in elevation between the tailwater control and the inlet and residual outlet depth is the difference in elevation between the tailwater control and the oulet. Culvert slope was calculated by dividing the difference between the inlet and outlet elevations by the length of the culvert and multiplying by 100, resulting in a percent gradient. Inlet width-ACW ratio was calculated by dividing culvert inlet width (measured in survey step 3) by ACW (measured in survey step 4).

A point to note is that Love and Taylor (2003) used a critical culvert slope value of $3 \%$ as a cutoff value for "red", or barrier, culverts. At first, a $3 \%$ slope seemed conservative for culverts crossing mountain streams where it is not uncommon to find brook trout in stream reaches steeper than $3 \%$. In fact, Adams et al. (2000) found that brook trout in several headwater streams in Idaho ascended stream channels with slopes of $13 \%$ for more than $67 \mathrm{~m}$ and $22 \%$ for more than $14 \mathrm{~m}$. However, high gradient streams and culverts do not behave similarly. In streams, flow is typically not as constricted as it is in culverts and the natural streambed substrate usually has a certain amount of associated roughness that creates resting habitat and slows down flow. All culverts we surveyed were made of either corrugated steel or concrete and these materials do not slow down flow. Moreover, most streams of this nature usually consist of step pools where trout can rest and culverts do not typically contain step pools. Culverts installed at greater than a $3 \%$ grade are probably "high-velocity” barriers at least part of the time and even partial barriers have the potential to impact fish communities (USFS 2002). For these reasons we decided to keep the value of $3 \%$ used by Love and Taylor (2003).

In our second objective, we quantified the proportion of road crossings that are likely barriers to fish passage. We also sought to determine the most common features of culverts (hang height, culvert slope, inlet width-ACW ratio, lack of continuous substrate within the 
culvert, or lack of residual inlet and outlet depth) that make them barriers and to determine whether certain physical stream features differed greatly between barrier culverts and partial or non-barrier culverts. The stream features we analyzed include: basin area at the culvert $\left(\mathrm{km}^{2}\right)$, ACW, and channel slope (\%). Channel slope was calculated by dividing the difference in elevation at the upstream and downstream ends of the reach by the reach length and multiplying this value by 100 , resulting in a percentage.

\section{Quantifying the Amount of Habitat Isolated by Culverts}

We used ArcGIS v8.3 to model and quantify the total length of stream in the study area that is isolated from downstream reaches by impassable culverts and to quantify a functional measure of brook trout spawning habitat isolated upstream of impassable culverts. For this functional measure of brook trout spawning habitat we used the weighted potential recruitment area (WPRA) index published in Petty and Thorne (2005). This index reflects both the length of stream as well as the relative ecological value of stream habitat located above each culvert. Weighted potential recruitment area was first used by Petty and Thorne (2005) to identify acid precipation-impacted stream restoration priorities in the Shavers Fork Watershed.

The WPRA for a given 1:24,000-scale stream segment was calculated by multiplying the length of the segment $(\mathrm{km})$ by the expected spawning intensity for that segment. Expected spawning intensity is a value ranging from 0 to 1 and is a measure of the expected level of brook trout spawning intensity given the basin area at the base of the stream segment. To predict spawning intensity, we used data from an earlier study that examined a variety of

physicochemical factors influencing brook trout spawning intensity (Petty et al. 2005). This study found that among many other factors basin area alone explained nearly $80 \%$ of variation in brook trout spawning and that spawning intensity was highest in streams draining less that 1 $\mathrm{km}^{2}$ and decreased rapidly with increasing basin area (Petty et al. 2005). Weighted potential 
recruitment area is also a product of an expected juvenile survivorship value. This value ranges from 0 to 1 given the alkalinity within the segment (high alkalinity reaches have higher juvenile survivorship). We assumed that all reaches in our study area had high alkalinity because our culvert inventory was conducted only in streams possessing relatively good water quality. Therefore, we assumed that expected juvenile survivorship was not a factor limiting brook trout recruitment in these reaches and values of 1 were assigned to all reaches.

Using ArcGIS v8.3, we first calculated the length of each stream segment within the study area using a 1:24,000-scale linear shapefile. We then summed the lengths of all segments within the study area as well as the lengths of all segments located above each culvert. Basin area was modeled using a filled 10 m digital elevation model (DEM) developed by the West Virginia University Natural Resource Analysis Center (NRAC) for the entire Cheat River Basin. We used the hydrology model sample extension 1.1 of ArcMap to derive a flow accumulation grid from the DEM. Using the flow accumulation grid the drainage area at any point within the basin could be calculated. We then attributed the basin area at the base of the segment to each stream segment as well as a basin area value to each culvert. We then derived expected spawning intensity from the basin area value for each segment.

After calculating WPRA for each segment, we summed the WPRA for all stream segments within the study area and for all segments located above each culvert. If there was a known impassable or partially impassable culvert located upstream we only summed the WPRA of segments upstream to, and not isolated by, that culvert. We used this total WPRA as an estimate of the relative extent of ecological loss that could be attributed to each culvert.

\section{Culvert Replacement Priorities}

After the culverts were assigned into passage categories using the fish passage evaluation filter (Figure 2) they were sorted by category. "Red" culverts were placed at the highest priority 
for replacement, followed by "gray” culverts, and "green” culverts were the lowest priority. We then sorted all of the culverts within each category by decreasing WPSA. This procedure resulted in a list of prioritized culvert replacement priorities to be presented to the West Virginia Division of Highways (WVDOH).

We then summed the WPRA loss extent above "red" culverts within each section and calculated the habitat loss intensity for each study section. Loss intensity is the total loss extent by "red" culverts divided by the total ideal WPRA for the study section given no disconnectivity within the stream network. We multiplied this value by 100 , resulting in a percentage. We then plotted loss intensity against loss extent and were able to identify one study section as the highest restoration priority.

\section{Results}

A majority (55\%) of culverts were circular and most (79 \%) were constructed of corrugated steel pipe. Other culvert types included pipe arch culverts (30 \%), box culverts (11 \%), and circular/box culvert combinations (4\%). Other construction materials included concrete (17\%), combinations of corrugated steel and stone (3\%), and combinations of concrete and stone (1\%). For a full set of culvert inventory data refer to White (2004).

Overall, we surveyed only 3 culverts that were classified as completely passable (green). Thirty-four culverts were partially impassable (gray) and a majority of culverts surveyed (83 culverts) were categorized as completely impassable (red) (Figure 4). By study section, the proportion of red culverts to all culverts surveyed ranged from $63 \%$ to $75 \%$ and Shavers Fork contained the most red culverts (Figure 5). All 120 culverts surveyed violated at least two of the critical criteria within the Love and Taylor (2003) filter and a majority (54\%) violated at least five (Figure 6). The most common violations involved a combination of low residual inlet or 
outlet depth, lack of streambed substrate within the culvert, high culvert slope, and inlet-ACW ratios of less than one (Figure 7).

Only $7 \%$ of culverts contained continuous streambed substrate along the culvert barrel (Figure 8). All 83 impassable culverts lacked a continuous layer of streambed substrate, while $79 \%$ of partially impassable culverts lacked a continuous layer of substrate, and only two out of three completely passable culverts lacked streambed substrate (Figure 9). Ninety-eight percent of culverts had a residual inlet or outlet residual depth less than $0.15 \mathrm{~m}$ (Figure 10). We found that proportions of impassable and partially passable culverts with a residual inlet or outlet depth of less than $0.15 \mathrm{~m}$ were $100 \%$ for both groups, while one out of the three passable culverts had a residual inlet or outlet depth of less than $0.15 \mathrm{~m}$ (Figure 11). Inlet-ACW ratio ranged from 0.13 to 1.85 with a mean of 0.77 among all culverts. Seventy-seven percent of culverts had an inlet width that was narrower than the mean active channel (Figures 12a and 12b). Outlet hang height ranged from $0 \mathrm{~m}$ to $1.75 \mathrm{~m}$ with a mean of $0.29 \mathrm{~m}$ among all culverts. Fifty-one percent of culverts were perched at the outlet and $13 \%$ had a hang height of over $0.61 \mathrm{~m}$, the critical outlet height in the fish passage filter (Figures 13a and 13b). Culvert slope ranged from $-0.1 \%$ to $16.5 \%$ with a mean of $5.11 \%$ and $68 \%$ of culverts had a slope of over $3 \%$ (Figures 14a and 14b).

Outlet hang and culvert slope were the two most important culvert characteristics creating barriers (Figures 15 and 16). The mean hang height was much higher among impassable culverts $(0.40 \mathrm{~m})$ than among partially impassable or completely passable culverts $(0.05 \mathrm{~m}$ and $0 \mathrm{~m}$, respectively) (Figure 15b). Additionally, the cumulative occurrence of red culverts increased with increasing hang height at a greater rate than the cumulative occurrence of all culverts at hang heights greater than zero, and especially at hang heights greater than $0.44 \mathrm{~m}$ (Figure 16b). Mean culvert slope was much higher among impassable culverts (7.0 \%) than among partially 
impassable and completely passable culverts (1.4\% and $2.4 \%$, respectively) (Figure 15c). The cumulative occurrence of red culverts increased at a greater rate than the cumulative occurrence of all culverts as culvert slopes increased over $3.0 \%$ (Figure 16c).

Survey reach channel slopes ranged from $0.1 \%$ to $30.8 \%$ with a mean of $7.6 \%$ among all culverts. Basin area at the culvert ranged from $0.45 \mathrm{~km}^{2}$ to $7.89 \mathrm{~km}^{2}$ with a mean of $1.62 \mathrm{~km}^{2}$ among all culverts. Active channel width ranged from $0.60 \mathrm{~m}$ to $5.89 \mathrm{~m}$ with a mean of $2.28 \mathrm{~m}$ among all culverts (Figure 15). Channel slope was, by far, the most important stream characteristic in determining the passability of culverts. Mean channel slope was much higher among impassable culverts (9.4 \%) than among partially impassable and completely passable culverts ( $4.0 \%$ and $2.5 \%$, respectively) (Figure15d). Additionally, the cumulative occurrence of "red" culverts tended to increase with increasing channel slope at a greater rate than the cumulative occurrence of all culverts at slopes greater than $3 \%$ (Figure 16d). Basin area may also have influenced whether culverts were barriers. Mean basin area was slightly lower among impassable culverts $\left(1.49 \mathrm{~km}^{2}\right)$ than among partially impassable or completely passable culverts (1.91 $\mathrm{km}^{2}$ and $1.99 \mathrm{~km}^{2}$, respectively) (Figure 13e).

At the culvert scale, we found that connectivity is recoverable to $10 \%$ of WPRA in our study area with the replacement of the top 17 impassable culverts with passable road crossing structures (Table 3). The final prioritized list of culvert replacement opportunities is located in Appendix I. Overall, $869 \mathrm{~km}$ of stream were located within the study area and a total of $207 \mathrm{~km}$ (24\%) were located above culverts. There were $575 \mathrm{~km}$ of WPRA within the study area and a total of $187 \mathrm{~km}$ (33\%) were located above culverts (Table 4). Completely impassable (red) culverts isolated $144 \mathrm{~km}$ (17\%) of stream length and $130 \mathrm{~km}$ (23\%) of WPRA within the study area (Figures 17 and 18). Shavers Fork had the highest WPRA loss extent (59 km) and intensity (26\%) within the study area due to habitat isolation by barrier culverts (Figure 19). 


\section{Discussion}

The requirement and direction to provide fish passage at road crossings is found in several documents (USFS 2002). The Clean Water Act [section 33, Code of Federal Regulations 323.3 (B)] states that "the design, construction and maintenance of the road crossing shall not disrupt the migration or other movement of those species of aquatic life inhabiting the waterbody.” Additionally, provisions of the Intermodal Surface Transportation Efficiency Act of 1991 (ISTEA) require that transportation planners, highway officials, and transit interests recognize environmental values and enhancement measures in transportation development programs (Bank 1996).

Given these provisions culverts should be installed so that they do not impede movement of fish or any other aquatic organism. However, the results presented here show that an overwhelming majority (69 \%) of state-owned culverts within our study area did not meet fish passage standards and an additional $28 \%$ are at least partial barriers that may still impede natural fish movements (Figure 4). In fact, only 3 culverts met fish passage standards. Clearly habitat loss and fragmentation due to culverting have the potential to greatly impact fish communities within the Cheat River Basin. Gibson et al. (2005) suggests that habitat loss and fragmentation should be considered as seriously as other perceived negative factors such as fisheries overexploitation or forestry and aquaculture practices.

The most common fish passage problems at culverts within our study area were inlet or outlet residual depths of less than $0.15 \mathrm{~m}$ (Figure 10) and the lack of continuous streambed substrate along the culvert barrel (Figure 8). However, a relatively similar proportion of impassable culverts violated these criteria compared to proportions of partially impassable and passable culverts (Figures 9 and 11). Although fewer culverts violated hang height and culvert slope criteria (Figures 13 and 14), it is apparent that these were the two major causes of 
impassable culverts within our study area. First, both mean hang height and mean culvert slope were much higher among red culverts than among gray or green culverts (Figures 15b and 15c). Second, the accumulation of red culverts increased at a much faster rate than the accumulation of all culverts along both increasing culvert slope and increasing hang height axes above respective filter criteria cutoff values (0.61 m for hang height and $3 \%$ for culvert slope) (Figures 16b and 16c). Similarly, Fitch (1995) found that two most significant fish passage problems occurring at six culverts in Bath, Alleghany, and Floyd counties, VA, were shallow flow depths (probably due to culverts that were placed at steeper gradients than the stream channel) and large outlet hang heights. Gibson et al. (2005) also found that the two most common fish passage problems at culverts were insufficient water depth and outlet hang.

We also found that culverts placed in streams with steep gradients are more prone to becoming barriers. Our reasoning is two-fold. First, mean channel slope was much higher among impassable culverts than among partially impassable or passable culverts (Figure 15d). In fact, it appears that culverts placed in streams with gradients over $5 \%$ are much more likely to be barrier culverts. Only $34 \%$ of culverts placed in streams with gradients less than $5 \%$ were classified as red compared to $87 \%$ of culverts placed in streams with gradients greater than $5 \%$. Second, the cumulative occurrence of red culverts increased at a much greater rate than the cumulative occurrence of all culverts with increasing channel slope (at channel slopes over 13 \%) (Figure 16d). This probably occured because many culverts were purposefully placed at less than stream-grade (personal observation), as has been suggested by some literature (e.g. Baker and Votapka 1990). The rationale for this common occurrence is that fish can negotiate substantially steeper streambeds than culverts (Baker and Votapka 1990). The problem is that when a culvert is placed at less than stream-grade then it is likely to become perched at the outlet if it is not countersunk sufficiently for the entire length of the barrel. Otherwise, a hydraulic 
jump is likely to occur at the inlet if the culvert is countersunk properly (Fitch 1995). The likelihood that the outlet will become perched increases greatly in steeper streams because it becomes substantially more difficult to properly countersink a culvert. Alternatively, culverts that are placed at stream-grade within steeper streams probably produce water velocities that are too extreme for fish passage. The final result is that any culvert placed in a steep stream will become a fish passage barrier, either because of outlet hang or because of high water velocities within the culvert barrel.

This result will hopefully aid engineers and environmental managers in predicting where fish passage problems are most likely to occur prior to future road building efforts. We know that culverts crossing streams with slopes over $5 \%$ are highly likely to become fish passage barriers. Stream slopes are easily modeled remotely in ArcGIS using a digital elevation model. By modeling stream slopes and identifying those streams with slopes greater than $5 \%$ crossing planned right-of-ways, it will be extremely easy to predict where barriers are likely to occur before road building begins and engineers will be able to design passable stream crossings accordingly.

The failure to properly design or install culverts within our study area probably exists for several reasons. First, many of these culverts are old and were installed before fish passage requirements were set. This failure could also be related to the large number of crossings, each one requiring a separate decision by the Division of Highways regarding the trade-off between cost and environmental considerations (Gibson et al. 2005). Often, environmental considerations are compromised because budgets are limited. For example, round corrugated steel pipe culverts were by far the most common road crossing within our study area even though they are the least ecologically-sound option. But round pipe is stronger than any other pipe and the most cost 
effective (Gibson et al. 2005), so it is often used instead of more expensive bridges or bottomless arch culverts that are better for fish passage.

Given the state of culvert crossings within this study area, the potential exists to restore connectivity to a large amount of stream habitat for native aquatic biota, including brook trout. In fact, approximately $17 \%$ of streams within the watershed are isolated by impassable culverts. Arguably, $17 \%$ of streams within the study area may experience some sort of ecological benefit through barrier replacement. Additionally, access to approximately $23 \%$ of critical spawning habitat (WPRA) within the watershed could potentially be restored to local brook trout populations upon impassable culvert replacement.

It should also be noted that we only surveyed state-owned culverts and there are many more private and US Forest Service culverts acting as fish movement barriers within the study area. Additionally, there are many natural barriers such as waterfalls. Consequently, the proportions of isolated habitat that we have presented are conservative estimates. There is probably much more habitat isolation within the upper Cheat River basin than we have measured.

Obviously the replacement of every barrier culvert cannot happen at once. However, the prioritized list of fish passage restoration opportunities at culvert crossings (Table 3) is a great starting point for culvert replacement decisions. But this is not a final replacement list. Further site visits will be necessary at potential restoration sites to assess additional factors and further rank culvert crossings accordingly. Love and Taylor (2003) suggest the following ranking criteria be assessed before final replacement decisions are made. Species diversity should be considered and the most speciose streams should be higher priorities. Habitat quality within the culverted stream reach should be quantified and higher quality streams should be higher priorities. Sizing of the culvert and flow capacity should be considered in tandem and culverts 
that are not adequately sized should be higher priorities. The physical condition of the culvert also is important and those culverts that are rusting through or smashed should be of a higher replacement priority than culverts that are in good condition. Finally, the presence or absence of other stream crossings is also important and, in many cases, a single stream may be crossed at multiple locations. If movement barriers exist at multiple crossings, a coordinated effort is required to identify and treat them in a logical manner, generally starting with the lowest crossing in the stream and working upstream (Love and Taylor 2003).

In addition to these general prioritization suggestions, we also suggest that barrier culverts within the upper Dry Fork study section (excluding Gandy Creek) and culverts crossing upper tributaries of the lower Dry Fork study section be placed at a lower priority than barrier culverts within Shavers Fork, Gandy Creek, or lower tributaries of lower Dry Fork. Flow within upper sections of Dry Fork often goes subsurface during the summer and many tributaries are ephemeral. Because of this, habitat within this section of the watershed is probably not as important to brook trout populations. Therefore, restoring connectivity here is likely not to have as much benefit to the regional fishery as restoring connectivity to perennial streams. Specifically, we suggest that the highest culvert replacement priority be placed on Shavers Fork because this was the study section with the greatest extent and intensity of brook trout spawning habitat isolation by impassable culverts.

When replacement priorities are finalized the next step will be to decide what type of stream crossing to install to maximize ecological benefit. Gibson et al. (2005) suggests that clear span, open-bottom, structures should be installed on all fish bearing streams. While this would maximize ecological benefit, it also would maximize costs, and minimize hydraulic and structural integrity, and is probably not necessary in all cases. Fitch (1995) concluded that culverts can be considered the primary option for crossing trout streams if the following criteria 
are met: the culvert can be placed on the same slope as that of the streambed, the slope of the stream is less than $3 \%$, the flow velocity does not exceed $1.2 \mathrm{~m} / \mathrm{s}$ under normal flow conditions, and the barrel of the culvert can be properly countersunk at the outlet to prevent perching. If these criteria are not met then bridges should be used (Fitch 1995). We agree with this suggestion, but unfortunately there are few streams that would allow a culvert to meet these criteria within our study area. Few of the streams surveyed have gradients under $3 \%$ due to the steep nature of the landscape of our study area, and those that do are not of the highest priority for replacement. The most common solution to fish passage problems in this basin will be to use bridges or open bottom arch crossings.

In conclusion, we find that the upper Cheat River basin is characterized by a high proportion of barrier culverts that cause discontinuities within the stream network and that this problem is, in addition to various other factors, sacrificing ecosystem health within the upper Cheat River basin. The most common causes of fish passage barriers were culvert slopes of over $3 \%$ and culvert hang heights over $0.61 \mathrm{~m}$. Moreover, culverts located in steeply sloped streams (> $5 \%$ ) are likely to act as fish passage barriers. We also found that the potential exists to restore connectivity to $17 \%$ of total stream length within the study area and $23 \%$ of critical brook trout spawning habitat through culvert barrier replacement. We developed a valid culvert replacement prioritization method. Although we performed this procedure only in one major basin, we believe it is applicable to other watersheds and can be implemented in any basin with culverted streams that support brook trout. It is feasible that this prioritization procedure could be used to prioritize restoration efforts at the large basin scale. We provided a prioritized list of fish passage restoration opportunities at culvert crossings for culvert replacement decisions by the West Virginia Division of Highways under the assumption that further evaluation is needed at all culverts being considered for replacement before final replacement decisions are made. 
We suggest that replacement work be performed in Shavers Fork first because this study section had both the highest extent and intensity of brook trout habitat loss. We suggest that culverts can be used at stream crossings if certain criteria are met, but the most common solution to fish passage problems in the upper Cheat River basin will be to install bottomless arch culverts or bridges due to the fact that most streams are steeply sloped. In these streams, culverts will inevitably become barriers to fish passage.

Finally, we successfully applied weighted potential recruitment area (WPRA) as a functional index of ecological loss due to culvert isolation. We feel that this unit of measure will be extremely useful within the central Appalachian region for several reasons. First, it will be an easy way to estimate ecological losses from new road development. Second, we feel that WPRA will be useful as a mitigation credit currency and for calculating the benefits of culvert replacement programs in the central Appalachians. Additionally, since WPRA was originally created as a functional measure of ecological loss due to acid precipitation (Petty and Thorne 2005), it stands as a potential currency for combining culvert replacement efforts with acid precipitation remediation. For example, a road-building agency could possibly receive mitigation credit for restoring acidified streams in roadless areas, using WPRA as currency. This credit could then be directly applied toward mitigation required because of culvert barrier effects at road crossings.

\section{Literature Cited}

Adams, S.B., C.A. Frissell, and B.E. Rieman. 2000. Movements of nonnative brook trout in relation to stream channel slope. Transactions of the American Fisheries Society 129: 623-638.

Baggett, A., E. Chiao, and T. Harton. 2001. Habitat conservation plan for the upper Etowah River watershed: road crossings-Effects and recommendations. Unpublished Manuscript. 33 pp. Available at http://www.rivercenter.uga.edu/education/etowah/documents/pdf/ hcp_bridges.pdf 
Baker, C.O., and F.E. Votapka. 1990. Fish passage through culverts. Federal Highway Administration Report No. FHWLA-FL-90-006. 67 pp.

Bank, G. B. 1996. Transportation planning: the watershed connection. Publication of the Office of Environment and Planning, Federal Highway Administration, Washington, D.C. 6pp.

Barbour, M.T., J. Gerritsen, B.D. Snyder, and J.B. Stribling. 1999. Rapid bioassessment protocols for use in streams and wadeable rivers: periphyton, benthic macroinvertebrates and fish, Second Edition. EPA 841-B-99-002. U.S. Environmental Protection Agency; Office of Water; Washington, D.C. 339 pp.

Baron, J. S., N. L. Poff, P. L. Angermeier, C. N. Dahm, P. H. Gleick, N. G. Hairston Jr., R. B. Jackson, C. A. Johnston, B. D. Richter, and A. D. Steinman. 2003. Sustaining healthy freshwater ecosystems. Issues in Ecology 10: 1-16.

Burrell, K. H., J. J. Isely, D. B. Bunnell, Jr., D. H. Van Lear, C. A. Dolloff. 2000. Seasonal movement of brown trout in a southern Appalachian river. Transactions of the American Fisheries Society 129: 1373-1379.

Dodds, W. K. 2002. Freshwater ecology: concepts and environmental applications. Academic Press, London.

Fausch, K. D., and M. K. Young. 1995. Evolutionary significant units and movement of resident stream fishes: a cautionary tale. American Fisheries Society Symposium 17: 360370.

Fitch, G. M. 1995. Nonanadromous fish passage in highway culverts. Virginia Transportation Research Council Report No. VTRC 96-R6. 18pp.

Flebbe, P. A. 1994. A regional view of the margin: salmonid abundance and distribution in the southern Appalachian mountains of North Carolina and Virginia. Transactions of the American Fisheries Society 123:657-667.

Gibson, R. J., R. L. Haedrich, and C. M. Wernerheim. 2005. Loss of fish habitat as a consequence of inappropriately constructed stream crossings. Fisheries 30: 10-17.

Gowan, C., and K. D. Fausch. 1996. Mobile brook trout in two high-elevation Colorado streams: re-evaluating the concept of restricted movement. Canadian Journal of Fisheries and Aquatic Sciences 53: 1370-1381.

Jackson, S. D. 2003. Ecological considerations in the design of river and stream crossings. Pages 20-29 in C.L. Irwin, P. Garrett, and K.P. McDermott, editors. Proceedings of the International Conference on Ecology and Transportation. Center for Transportation and the Environment, North Carolina State University, Raleigh, North Carolina. 
Kahler, T. H., and T. P. Quinn. 1998. Juvenile and resident salmonid movement and passage through culverts. Final Research Report to the Washington State Transportation Center: 38 pp.

Losche, C. K., and W. W. Beverage. 1967. Soil survey of Tucker County and part of northern Randolph county, West Virginia. United States Department of Agriculture-Soil Conservation Service and Forest Service. 134 pp.

Love, M and R. N. Taylor. 2003. Fish passage evaluation at stream crossings. California Salmonid Stream Habitat Restoration Manual Part IX. available at http://www.dfg.ca.gov/nafwb/pubs/2003/FishPassage.pdf

Marschall, E. A., and L. B. Crowder. 1996. Assessing population responses to multiple anthropogenic effects: a case study with brook trout. Ecological Applications 6:152-167.

McClellan, T. J. 1970. Fish passage through highway culverts, a Field Evaluation. Federal Highway Administration, U.S. Department of Transportation, Region 8. 16 pp.

Nagel, J. W. 1991. The decline of the brook trout in the southern Appalachians resulting from competetive exclusion and/or extinction due to habitat fragmentation? Journal of the Tennessee Academy of Science 66: 141-143.

Petty, J. T., P. A. Lamothe, and P. M. Mazik. 2005. Spatial and seasonal dynamics of brook trout populations in a central Appalachian watershed. Transactions of the American Fisheries Society 134: 572-587.

Petty, J.T., and D. Thorne. 2005. An ecologically based approach to identifying restoration priorities in an acid-impacted watershed. Restoration Ecology 13: 348-357.

Poff, N. L., and J. V. Ward. 1989. Implications of stream-flow variability and predictability for lotic community structure: a regional analysis of streamflow patterns. Canadian Journal of Fisheries and Aquatic Sciences 46: 1805-1818.

Pringle, C. M., R. J. Naiman, G. Bretschko, J. R. Karr, M. W. Oswood, J. R.Webster, R. L. Welcomme, and M. J. Winterbourn. 1988. Patch dynamics in lotic systems: the stream as a mosaic. Journal of the North American Benthological Society 7: 503-524.

Pyle, R. E., W. W. Beverage, T. Yoakum, D. P. Amick, W. F. Hatfield, and D. E. McKinney. 1982. Soil survey of Randolph County area, main part, West Virginia. United States Department of Agriculture-Soil Conservation Service and Forest Service. pp. 167.

Riley, S. C., K. D. Fausch, and C. Gowan. 1992. Movement of brook trout (Salvelinus fontinalis) in four small subalpine streams in Northern Colorado. Ecology of Freshwater Fish 1: $112-122$. 
Scarsbrook, M. R., and C. R. Townsend. 1993. Stream community structure in relation to spatial and temporal variation: a habitat templet study of two contrasting New Zealand streams. Freshwater Biology 29: 395-410.

Thompson, P. D, and F. J. Rahel. 1998. Evaluation of artificial barriers in small Rocky Mountain streams for preventing the upstream movement of brook trout. North American Journal of Fisheries Management 18: 206-210.

USFS (United States Forest Service). 2002. A summary of technical considerations to minimize the blockage of fish at culverts on the national forests of Alaska. Supplement to USFS briefing paper titled “Fish Passage on Alaska’s National Forests.” USFS, Alaska Region: 7pp.

Ward, R. 2005. The effects of roads and culverts on stream and stream-side salamander communities in Eastern West Virginia. Master’s Thesis, West Virginia University. 181 pp.

Warren, Jr., M. L., and M. G. Pardew. 1998. Road crossings as barriers to small-stream fish movement. Transactions of the American Fisheries Society 127: 637-644.

White, J. A. 2004. Geomorphic analysis of stream crossings in a portion of the upper Cheat River basin. Master's Thesis, West Virginia University. 71 pp. 


\section{Tables}

Table 1: Physical characteristics of the three sections of study during summer 2003 culvert surveys within the upper Cheat River basin including boundary area, minimum elevation, maximum elevation, area of forested land-cover, dominant soil associations (Pyle et al. 1982; Losche and Beverage 1967), and the top three surficial geological units within each watershed ordered by surface area $\left(\mathrm{km}^{2}\right)$.

\begin{tabular}{|c|c|c|c|c|c|}
\hline section & $\begin{array}{l}\text { area } \\
\left(\mathrm{km}^{2}\right)\end{array}$ & $\begin{array}{l}\text { min. } \\
\text { elev. } \\
(m)\end{array}$ & $\begin{array}{l}\text { max. } \\
\text { elev. } \\
(m)\end{array}$ & $\begin{array}{c}\text { forested } \\
\text { area } \\
\left(\mathrm{km}^{2}\right)\end{array}$ & $\begin{array}{c}\text { surficial geology: } \\
\text { area }\left(\mathrm{km}^{2}\right)\end{array}$ \\
\hline
\end{tabular}

$\begin{array}{lllll}\text { upper } & 143.6 \quad 806 \quad 1,416 \quad 113.9 & \begin{array}{l}\text { Hampshire: } 58.1 \\ \text { Mauch Chunk: } 43.1 \\ \text { Dry Fork }\end{array} \\ \text { Chemung: } 12.8\end{array}$

$\begin{array}{llllll}\text { lower } & & & & \text { Mauch Chunk: } 88.1 \\ \text { Dry Fork } & 311.2 & 494 & 1,496 \quad 263.9 & \begin{array}{l}\text { Pottsville: } 86.9 \\ \text { Hampshire: } 55.1\end{array}\end{array}$

$\begin{array}{llllll}\text { Shavers } & 554.3 \quad 518 \quad 1,472 & 518.5 & \begin{array}{l}\text { Pottsville: } 248.8 \\ \text { Mauch Chunk: } 147.9 \\ \text { Chemung: } 114.5\end{array} \\ \text { Fork } & & & & \end{array}$


Table 2: List of the data collected at 120 culvert locations during culvert surveys, summer 2003.

\begin{tabular}{|c|c|}
\hline culvert survey step & data collected \\
\hline $\begin{array}{l}\text { Step 1: Descriptive } \\
\text { Information }\end{array}$ & $\begin{array}{l}\text { Road.Number } \\
\text { Road Type (Unimproved, Gravel, Paved; 1-lane, 2-lane, 4-lane) } \\
\text { Basin/Watershed } \\
\text { Stream Name } \\
\text { USGS 1:24,000 Quadrangle } \\
\text { County } \\
\text { UTM Coordinates } \\
\text { Datum (NAD27, NAD83, WGS84) } \\
\text { GPS Accuracy (m) }\end{array}$ \\
\hline $\begin{array}{l}\text { Step 2: Site } \\
\text { Conditions }\end{array}$ & $\begin{array}{l}\text { Flow (Dry, Isolated Pools, Low, Moderate, High, Very High) } \\
\text { Severe Water Quality Impairment (Y/N) } \\
\text { Channel Relocation (Y/N) } \\
\text { Adjacent Land Use Conditions (Nearly Pristine, Low Impact Wooded, Low Impact Open, } \\
\text { Moderate Impact, } \\
\quad \text { Severe Impact) } \\
\text { Aquatic Organisms Observed (Salamanders, Fish, Crayfish, Benthic Invertebrates) }\end{array}$ \\
\hline $\begin{array}{l}\text { Step 3: Culvert } \\
\text { Aspects }\end{array}$ & $\begin{array}{l}\text { Inlet Type (Projecting, Headwall, Wingwall, Mitered, Flared) } \\
\text { Stream-Inlet Alignment Angle (degrees) } \\
\text { Stream-Outlet Alignment Angle (degrees) } \\
\text { Outlet Configuration (Stream Grade, Free-Fall Into Pool, Cascade Over Rip-Rap) } \\
\text { Tailwater Control (Pool Tailout, Debris Jam, Concrete Weir, Log Weir, Boulder Weir, No } \\
\text { Control) } \\
\text { Culvert Type (Circular, Pipe Arch, Box) } \\
\text { Culvert Material (Corrugated Steel Pipe, Aluminum Pipe, Stone, Concrete, Wood, Other) } \\
\text { Culvert Diameter (m) } \\
\text { Culvert Length (m) } \\
\text { Corrugations (Width x Depth, m) } \\
\text { Pipe Condition (Good, Fair, Poor) } \\
\text { Percent Blockage at Inlet (\% Sediment, \% Large Woody Debris) } \\
\text { Embedded (Y/N) } \\
\text { Sediment Thickness (At Inlet, At Outlet) } \\
\text { Culvert Substrate Description } \\
\text { Outlet Hang (Y/N) } \\
\text { Height of Hang (m) } \\
\text { Presence of Baffles or Weirs for Fish Passage (Y/N) } \\
\text { Adult Fish Migration Barrier (Complete, Partial, None) } \\
\text { Juvenile Fish Migration Barrier (Complete, Partial, None) } \\
\text { Salamander Migration Barrier (Complete, Partial, None) } \\
\text { Roadway Impacts (Excessive Runoff, Expanded Basin Area, Road Bed Scour, Road Bed } \\
\quad \text { Gullying) }\end{array}$ \\
\hline $\begin{array}{l}\text { Step 4: Channel } \\
\text { and Reach } \\
\text { Dimensions }\end{array}$ & $\begin{array}{l}\text { Mean Bankfull Width (Mean of Four Measurements, m) } \\
\text { Mean Bankfull Depth (Mean of Four Measurements, m) } \\
\text { Mean Active Channel Width (Mean of Four Measurements, m) } \\
\text { Reach Length ( } 30 \text { x Mean Active Channel Width, Min=30m, Max=100m) }\end{array}$ \\
\hline
\end{tabular}




\begin{tabular}{|c|c|}
\hline \multirow{12}{*}{$\begin{array}{l}\text { Step 5: Geology, } \\
\text { Soils, and } \\
\text { Geomorphology } \\
\text { Information }\end{array}$} & Bedrock Unit \\
\hline & Distance to Nearest Outcrop (m) \\
\hline & Lithology \\
\hline & Surficial Geology Observations \\
\hline & Estimated Rosgen Stream Classification \\
\hline & Introduced Anthropogenic Materials \\
\hline & Soil Series \\
\hline & Soil Texture \\
\hline & Stable Reach (Y/N, Evidence) \\
\hline & Above Culvert Bank Scour (Y/N, dimensions) \\
\hline & Below Culvert Bank Scour (Y/N, dimensions) \\
\hline & Aggradation (Y/N, dimensions) \\
\hline \multirow{13}{*}{$\begin{array}{l}\text { Step 6: In-stream } \\
\text { Habitat and } \\
\text { Riparian Corridor } \\
\text { Condition }\end{array}$} & EPA RVHA Score (Above, Below, Mean) \\
\hline & Continuous Substrate for Salamander Cover (Y/N; Above, Below, Under/Adjacent) \\
\hline & Distance to Suitable Substrate Size (Above, Below, m) \\
\hline & Estimated Percent Canopy Cover of Established Forest Vegetation (Above, Below; Left, \\
\hline & Shrubs, Herbs) \\
\hline & Estimated Percent Canopy Cover of “Altered” Vegetation (Above, Below; Left, Right; \\
\hline & Distance from Culvert to Riparian Trees/Shrubs (Above, Below; Left, Right) \\
\hline & Barrier to Riparian Species Movement (Y/N; Left, Right) \\
\hline & Elevation at the Head of the Riffle Nearest the Upstream End of the Survey Reach (m) \\
\hline & Inlet Elevation (m) \\
\hline & Inlet Water Depth (m) \\
\hline & Outlet Elevation (m) \\
\hline & Oulet Water Depth (m) \\
\hline \multirow{8}{*}{$\begin{array}{l}\text { Step 7: } \\
\text { Longitudinal } \\
\text { Stream Survey }\end{array}$} & Elevation at the Deepest Point within the Outlet Pool (m) \\
\hline & Water Depth at the Deepest Point within the Outlet Pool (m) \\
\hline & Elevation at the Deepest Point within $2 \mathrm{~m}$ of the Outlet (m) \\
\hline & Water Depth at the Deepest Point within $2 \mathrm{~m}$ of the Outlet (m) \\
\hline & Elevation at the Tailwater Control (m) \\
\hline & Water Depth at the Tailwater Control (m) \\
\hline & Elevation of the Active Channel Margin at the Tailwater Control (m) \\
\hline & $\begin{array}{l}\text { Elevation at the Head of the Riffle Nearest the Downstream End of the Survey Reach (m) } \\
\text { Elevations at Major Slope Breaks (m) }\end{array}$ \\
\hline
\end{tabular}


Table 3: The top 20 culvert replacement priorities within our study area ranked by weighted potential recruitment area (WPRA) located upstream of each culvert.

\begin{tabular}{|c|c|c|c|c|c|c|c|c|c|c|c|}
\hline Rank & $\begin{array}{c}\text { Stream } \\
\text { Name }\end{array}$ & $\begin{array}{c}\text { Study } \\
\text { Section }\end{array}$ & $\begin{array}{l}\text { Inlet } \\
\text { Width- } \\
\text { ACW } \\
\text { Ratio } \\
\end{array}$ & $\begin{array}{c}\text { Outlet } \\
\text { Hang } \\
\text { Height }(m)\end{array}$ & $\begin{array}{l}\text { Culvert } \\
\text { Slope } \\
(\%)\end{array}$ & $\begin{array}{l}\text { Channel } \\
\text { Slope } \\
(\%)\end{array}$ & $\begin{array}{l}\text { Basin } \\
\text { Area } \\
\left(\mathrm{km}^{2}\right)\end{array}$ & $\begin{array}{l}\text { Active } \\
\text { Channel } \\
\text { Width } \\
(m)\end{array}$ & $\begin{array}{c}\text { Upstream } \\
\text { WPRA } \\
(\mathrm{km})\end{array}$ & $\begin{array}{l}\text { Recoverable } \\
\text { WPRA (\% of } \\
\text { study area) }\end{array}$ & $\begin{array}{l}\text { Cumulative } \\
\text { Recoverable } \\
\text { WPRA (\% of } \\
\text { Study Area) }\end{array}$ \\
\hline 1 & $\begin{array}{l}\text { Elk Lick } \\
\text { Run }\end{array}$ & $\begin{array}{c}\text { lower Dry } \\
\text { Fork }\end{array}$ & 0.62 & 1.20 & 3.4 & 7.2 & 5.23 & 3.27 & 8.68 & 1.51 & 1.51 \\
\hline 2 & Big Run & $\begin{array}{l}\text { lower Dry } \\
\text { Fork }\end{array}$ & 1.85 & 0.48 & 3.2 & 5.3 & 4.05 & 1.66 & 5.13 & 0.89 & 2.40 \\
\hline 3 & $\begin{array}{l}\text { Little Laurel } \\
\text { Run }\end{array}$ & $\begin{array}{l}\text { Shavers } \\
\text { Fork }\end{array}$ & 0.64 & 0.13 & 4.9 & 5.1 & 0.60 & 1.00 & 4.66 & 0.81 & 3.21 \\
\hline 4 & $\begin{array}{l}\text { unnamed } \\
\text { tributary }\end{array}$ & $\begin{array}{l}\text { Shavers } \\
\text { Fork }\end{array}$ & 0.51 & 0.55 & 7.0 & 17.3 & 1.53 & 3.30 & 3.67 & 0.64 & 3.85 \\
\hline 5 & $\begin{array}{l}\text { unnamed } \\
\text { tributary }\end{array}$ & $\begin{array}{l}\text { upper } \\
\text { Dry Fork }\end{array}$ & 0.34 & 0.00 & 3.4 & 5.3 & 3.91 & 4.36 & 3.41 & 0.59 & 4.44 \\
\hline 6 & $\begin{array}{l}\text { Lower Two } \\
\text { Spring Run }\end{array}$ & $\begin{array}{l}\text { upper } \\
\text { Dry Fork }\end{array}$ & 0.68 & 1.35 & 15.9 & 7.9 & 4.86 & 5.28 & 3.35 & 0.58 & 5.02 \\
\hline 7 & $\begin{array}{l}\text { Warner } \\
\text { Run }\end{array}$ & $\begin{array}{l}\text { upper } \\
\text { Dry Fork }\end{array}$ & 0.63 & 0.20 & 3.4 & 4.8 & 2.82 & 2.25 & 3.07 & 0.54 & 5.56 \\
\hline 8 & $\begin{array}{c}\text { Sugar } \\
\text { Camp Run }\end{array}$ & $\begin{array}{l}\text { Shavers } \\
\text { Fork }\end{array}$ & 0.60 & 0.23 & 13.3 & 15.4 & 1.29 & 3.48 & 3.03 & 0.52 & 6.08 \\
\hline 9 & $\begin{array}{l}\text { unnamed } \\
\text { tributary }\end{array}$ & $\begin{array}{l}\text { Shavers } \\
\text { Fork }\end{array}$ & 0.91 & 0.06 & 3.2 & 3.0 & 3.16 & 2.70 & 3.00 & 0.52 & 6.60 \\
\hline 10 & $\begin{array}{l}\text { Grants } \\
\text { Branch }\end{array}$ & $\begin{array}{c}\text { upper } \\
\text { Dry Fork }\end{array}$ & 0.39 & 0.00 & 8.2 & 6.2 & 3.81 & 2.55 & 2.82 & 0.50 & 7.10 \\
\hline
\end{tabular}


Table 3 continued

\begin{tabular}{|c|c|c|c|c|c|c|c|c|c|c|c|}
\hline Rank & $\begin{array}{l}\text { Stream } \\
\text { Name }\end{array}$ & $\begin{array}{l}\text { Study } \\
\text { Section }\end{array}$ & $\begin{array}{l}\text { Inlet } \\
\text { Width- } \\
\text { ACW } \\
\text { Ratio }\end{array}$ & $\begin{array}{c}\text { Outlet } \\
\text { Hang } \\
\text { Height }(m)\end{array}$ & $\begin{array}{c}\text { Culvert } \\
\text { Slope } \\
(\%)\end{array}$ & $\begin{array}{c}\text { Channel } \\
\text { Slope } \\
(\%)\end{array}$ & $\begin{array}{l}\text { Basin } \\
\text { Area } \\
\left(\mathrm{km}^{2}\right)\end{array}$ & $\begin{array}{l}\text { Active } \\
\text { Channel } \\
\text { Width } \\
(m)\end{array}$ & $\begin{array}{c}\text { Upstream } \\
\text { WPRA } \\
(\mathrm{km})\end{array}$ & $\begin{array}{c}\text { Recoverable } \\
\text { WPRA (\% of } \\
\text { study area) }\end{array}$ & $\begin{array}{c}\text { Accumulation } \\
\text { of Recoverable } \\
\text { WPRA (\% of } \\
\text { Study Area) }\end{array}$ \\
\hline 11 & $\begin{array}{l}\text { Wamsley } \\
\text { Run }\end{array}$ & $\begin{array}{l}\text { Shavers } \\
\text { Fork }\end{array}$ & 0.33 & 0.52 & 5.4 & 6.9 & 1.30 & 2.17 & 2.81 & 0.49 & 7.58 \\
\hline 12 & $\begin{array}{l}\text { Walker } \\
\text { Run }\end{array}$ & $\begin{array}{l}\text { Shavers } \\
\text { Fork }\end{array}$ & 0.31 & 0.07 & 7.8 & 5.7 & 2.54 & 3.70 & 2.80 & 0.49 & 8.07 \\
\hline 13 & $\begin{array}{l}\text { Stonelick } \\
\text { Run }\end{array}$ & $\begin{array}{l}\text { Shavers } \\
\text { Fork }\end{array}$ & 0.49 & 0.42 & 3.8 & 4.6 & 2.55 & 3.30 & 2.74 & 0.48 & 8.55 \\
\hline 14 & Wolf Run & $\begin{array}{l}\text { Shavers } \\
\text { Fork }\end{array}$ & 1.76 & 0.50 & 7.5 & 7.6 & 2.17 & 1.90 & 2.64 & 0.45 & 9.00 \\
\hline 15 & $\begin{array}{l}\text { Little Laurel } \\
\text { Run }\end{array}$ & $\begin{array}{l}\text { Shavers } \\
\text { Fork }\end{array}$ & 0.77 & 0.45 & 7.7 & 5.4 & 1.60 & 2.88 & 2.46 & 0.43 & 9.43 \\
\hline 16 & $\begin{array}{l}\text { Pond } \\
\text { Creek }\end{array}$ & $\begin{array}{l}\text { lower Dry } \\
\text { Fork }\end{array}$ & 0.53 & 0.00 & 8.5 & 9.6 & 1.77 & 1.97 & 2.35 & 0.41 & 9.84 \\
\hline 17 & $\begin{array}{l}\text { Upper Two } \\
\text { Spring Run }\end{array}$ & $\begin{array}{l}\text { upper } \\
\text { Dry Fork }\end{array}$ & 1.19 & 0.50 & 7.1 & 9.8 & 4.51 & 5.89 & 2.23 & 0.39 & 10.23 \\
\hline 18 & $\begin{array}{l}\text { Spruce } \\
\text { Run }\end{array}$ & $\begin{array}{l}\text { Shavers } \\
\text { Fork }\end{array}$ & 0.65 & 0.00 & 4.7 & 14.9 & 1.56 & 2.72 & 2.20 & 0.38 & 10.61 \\
\hline 19 & $\begin{array}{l}\text { unnamed } \\
\text { tributary }\end{array}$ & $\begin{array}{l}\text { lower Dry } \\
\text { Fork }\end{array}$ & 0.89 & 0.50 & 9.7 & 8.8 & 1.60 & 1.20 & 2.20 & 0.38 & 10.99 \\
\hline 20 & Natt Run & $\begin{array}{l}\text { Shavers } \\
\text { Fork }\end{array}$ & 0.41 & 0.00 & 12.3 & 6.4 & 2.62 & 2.83 & 1.89 & 0.33 & 11.32 \\
\hline
\end{tabular}


Table 4: Length of stream and weighted potential recruitment area (WPRA) located above all culverts, red and gray culverts only, red culverts only, as well as total available within each section. Both study section and study area totals are given.

\begin{tabular}{|c|c|c|c|c|c|c|c|c|}
\hline study section & \multicolumn{2}{|c|}{ all culverts } & \multicolumn{2}{|c|}{ red and gray culverts } & \multicolumn{2}{|c|}{ red culverts } & \multicolumn{2}{|c|}{ total available } \\
\hline upper Dry Fork & 51.1 & 42.3 & 46.8 & 38.0 & 32.2 & 25.8 & 182.0 & 117.7 \\
\hline Shavers Fork & 86.5 & 79.2 & 86.5 & 79.2 & 65.5 & 60.8 & 351.7 & 228.9 \\
\hline total & 207.4 & 187.4 & 201.9 & 182.4 & 144.2 & 129.5 & 868.7 & 575.3 \\
\hline
\end{tabular}




\section{Figures}

Figure 1: Map of the upper Cheat River basin, West Virginia, except the Blackwater River, with the three study area sections outlined in bold. Culverts surveyed during the summer of 2003 are represented as black dots. Specifically, the study area consists of the following study sections: upper Dry Fork (above the Gandy Creek confluence), Lower Dry Fork, and Shavers Fork.

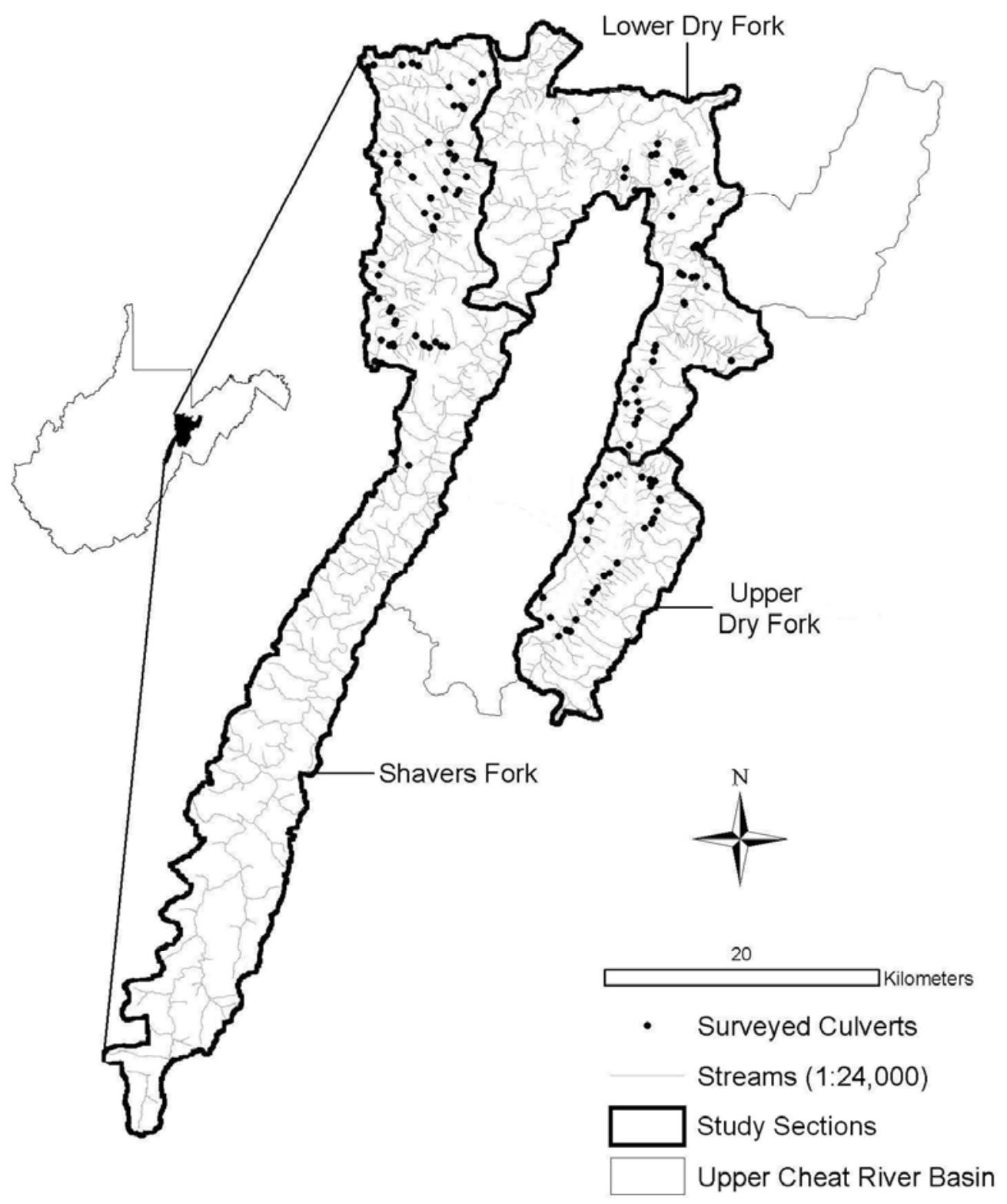


Figure 2: Green-Gray-Red fish passage evaluation filter from Love and Taylor (2003). We adopted the fish passage ranking criteria from this filter for use in our analysis.

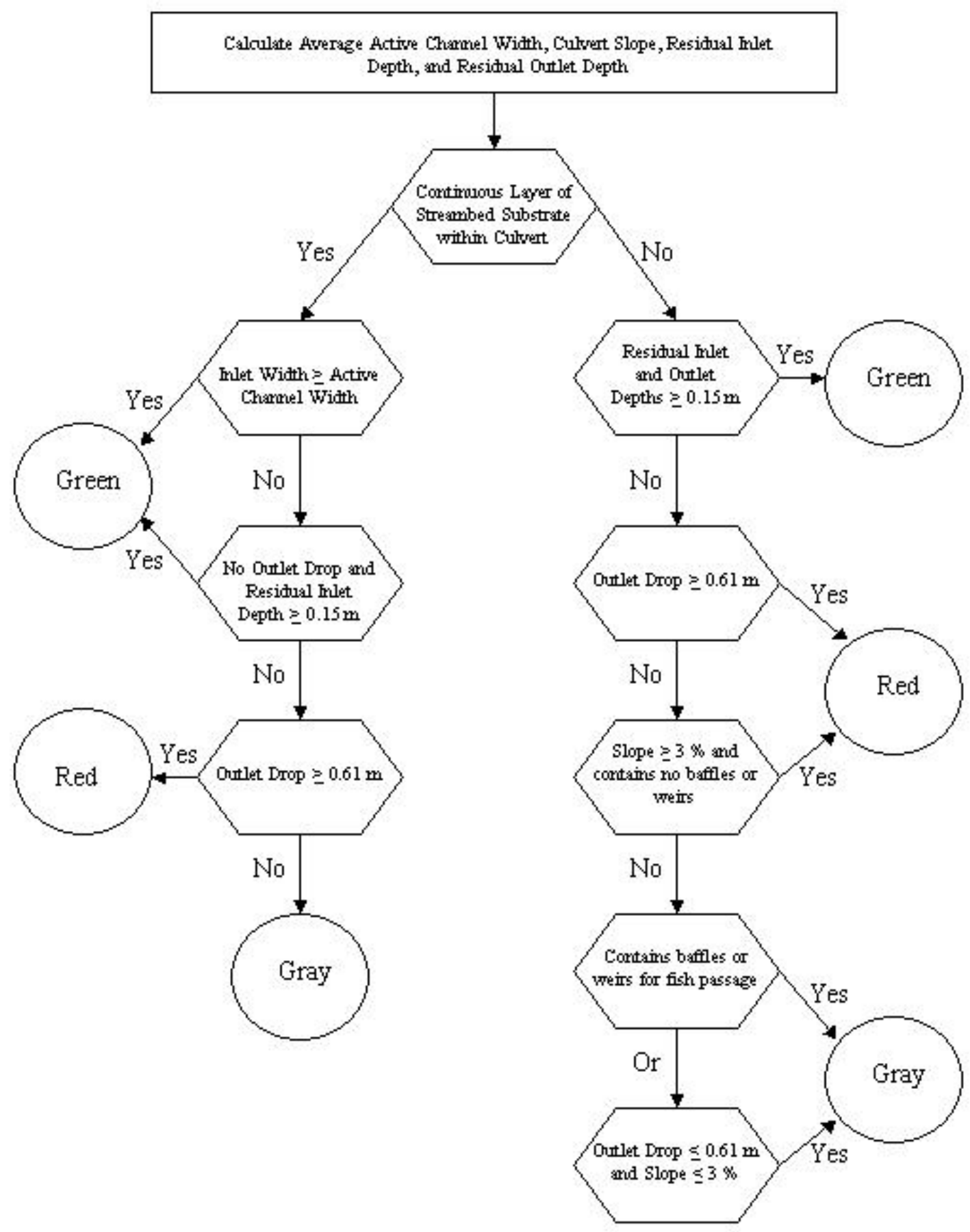


Figure 3: Residual inlet and outlet depth equations as well as other critical measurements used in fish passage evaluation filter (Love and Taylor 2003).

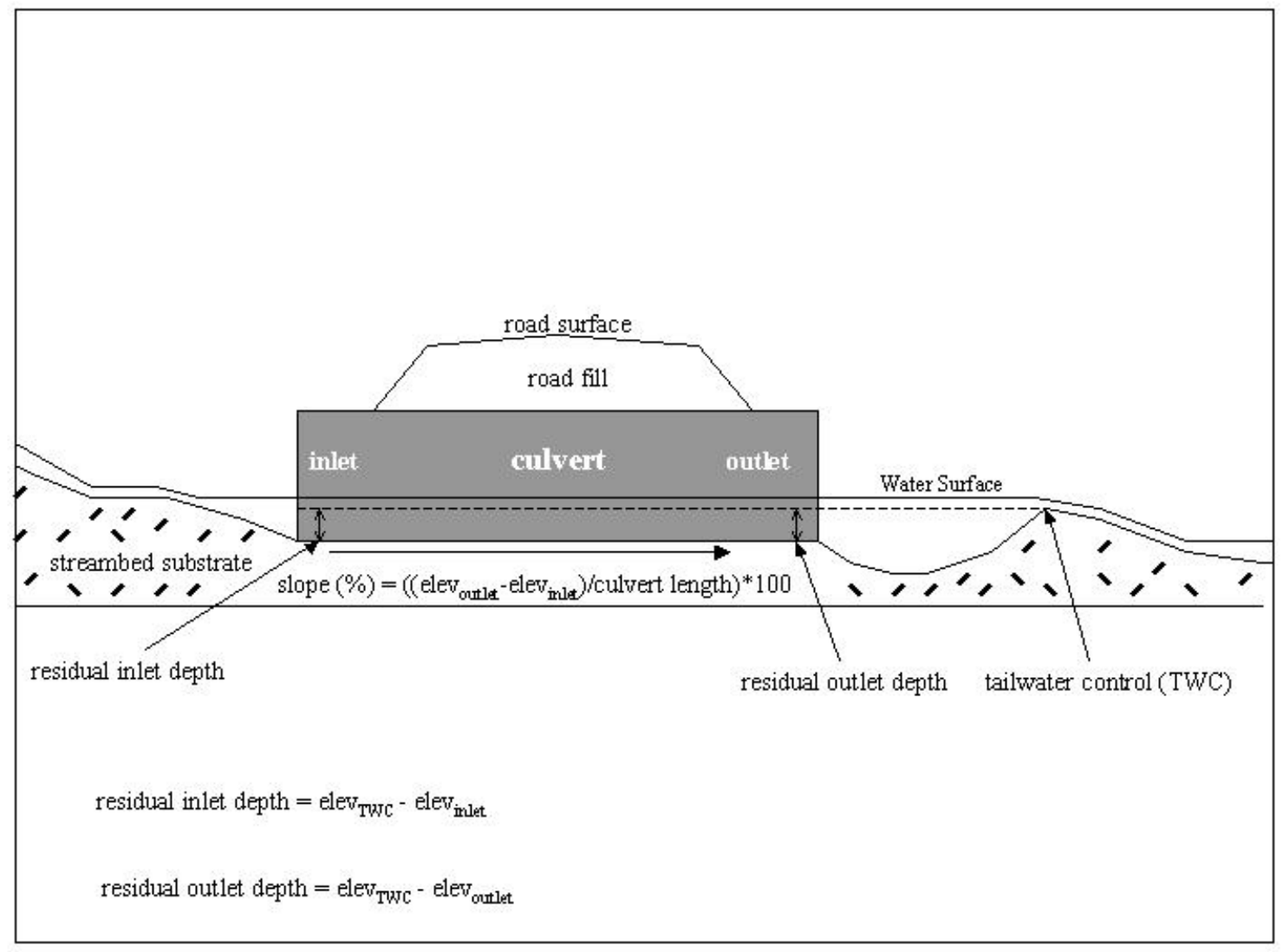


Figure 4: One-hundred and twenty culverts were evaluated using the fish passage evaluation filter from Love and Taylor (2003). This histogram displays the relative frequency of culverts within each filter category. Green culverts are completely passable, gray culverts are partially impassable, and red culverts are completely impassable.

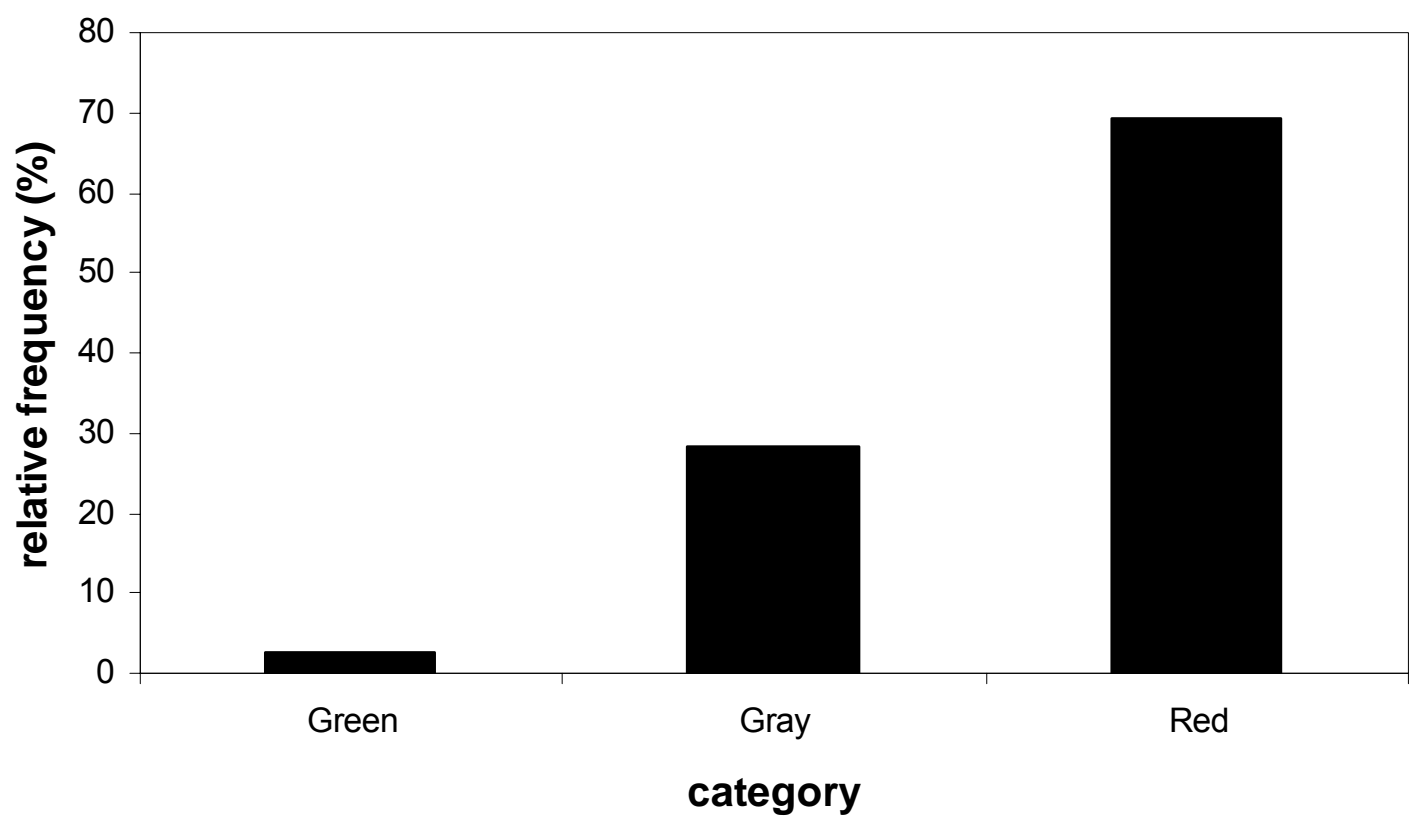

Figure 5: Proportion of culverts within each study section and proportion of all culverts surveyed $(\mathrm{n}=120)$ that were categorized as "red" culverts.

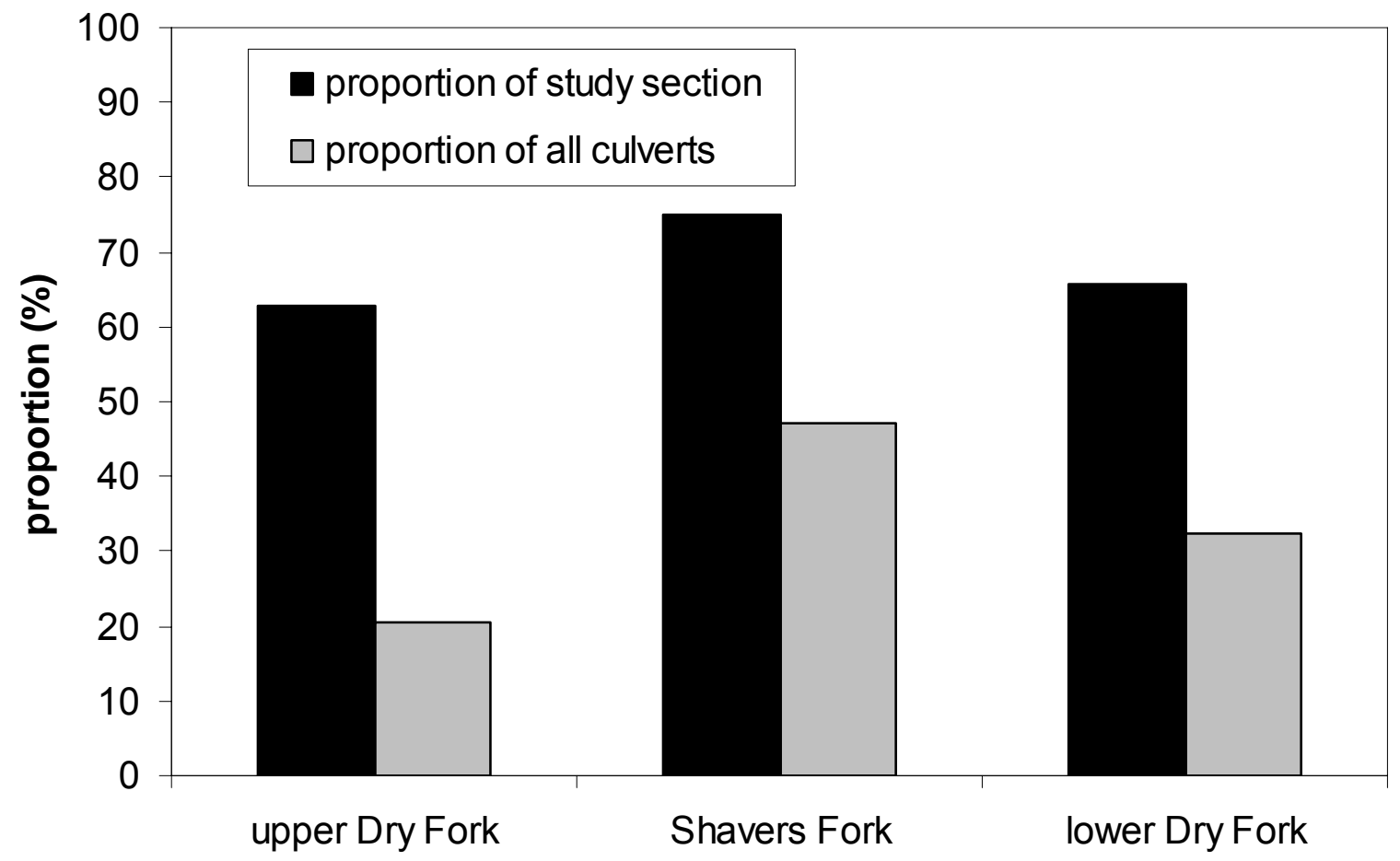


Figure 6: Proportion of total culverts surveyed that violated $0,1,2,3,4$, and 5 of the major criteria from the fish passage evaluation filter of Love and Taylor (2003).

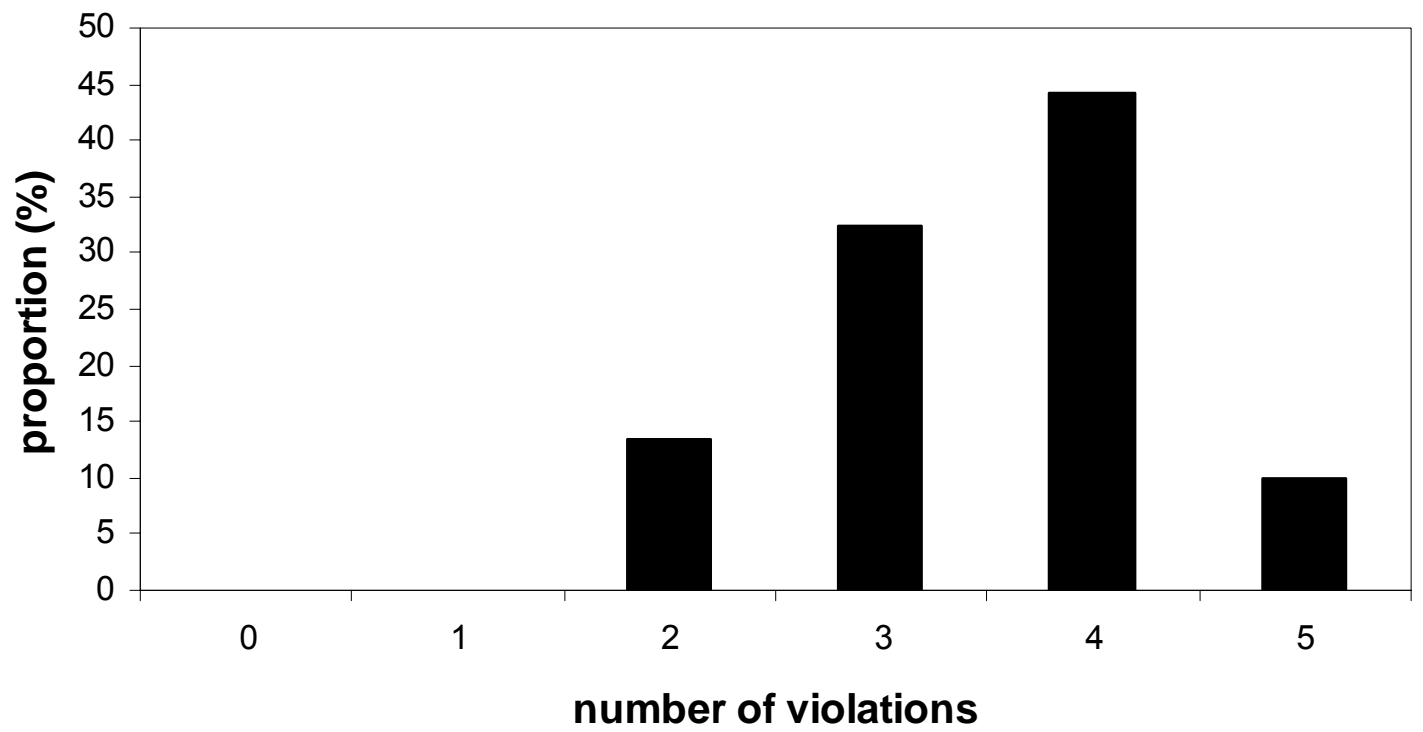

Figure 7: Combinations of violations of the five major criteria $(\mathrm{C}=$ no continuous substrate through the culvert barrel, $\mathrm{Ra}=$ active channel width greater than inlet width, $\mathrm{Re}=$ residual inlet and outlet depths under $0.15 \mathrm{~m}, \mathrm{~S}=$ culvert slope over $3 \%, \mathrm{H}=$ outlet hang over $0.61 \mathrm{~m}$ ) used in the fish passage evaluation filter of Love and Taylor (2003). Displayed are the proportion of total culverts surveyed that were characterized by each violation combination.

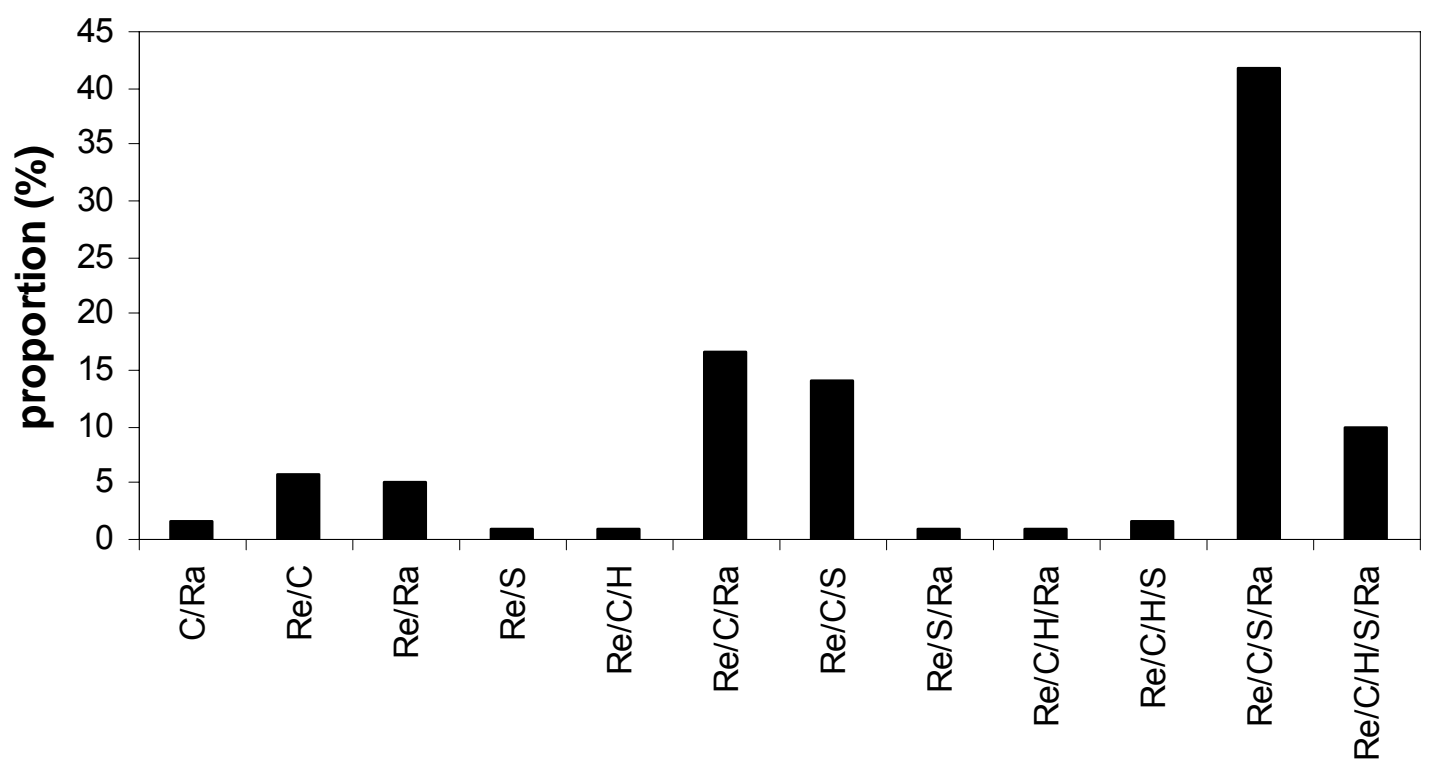

violations 
Figure 8: Proportion of all culverts $(n=120)$ that contained continuous streambed substrate versus the proportion that did not. A majority of culverts (93\%) did not have a continuous layer of streambed substrate.

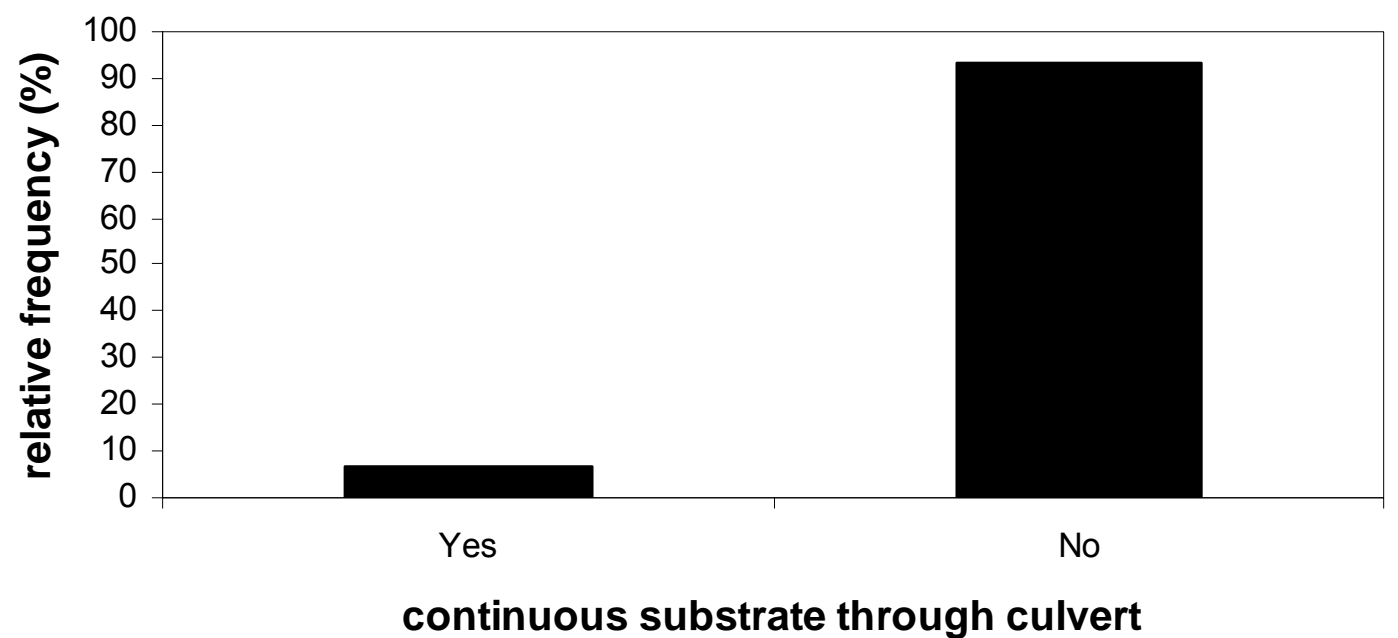

Figure 9: Proportion of culverts within each fish passage category that did not contain a continuous layer of streambed substrate. Green culverts are completely passable, gray culverts are partially impassable, and red culverts are completely impassable.

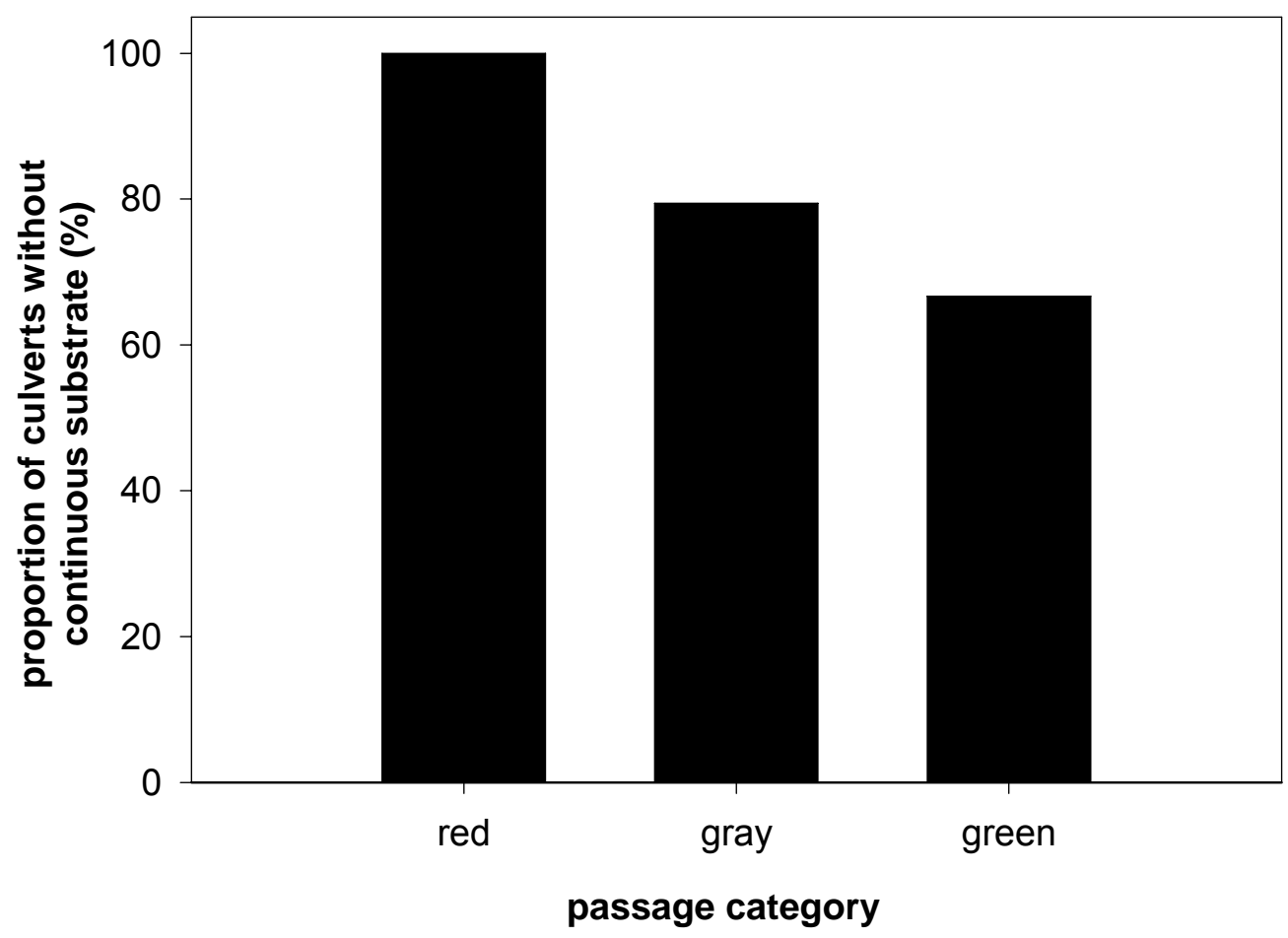


Figure 10: Proportion of culverts that had residual inlet and outlet depths greater than $0.15 \mathrm{~m}$ versus the proportion did not. A majority of culverts (98\%) did not have residual inlet and outlet depths of over $0.15 \mathrm{~m}$.

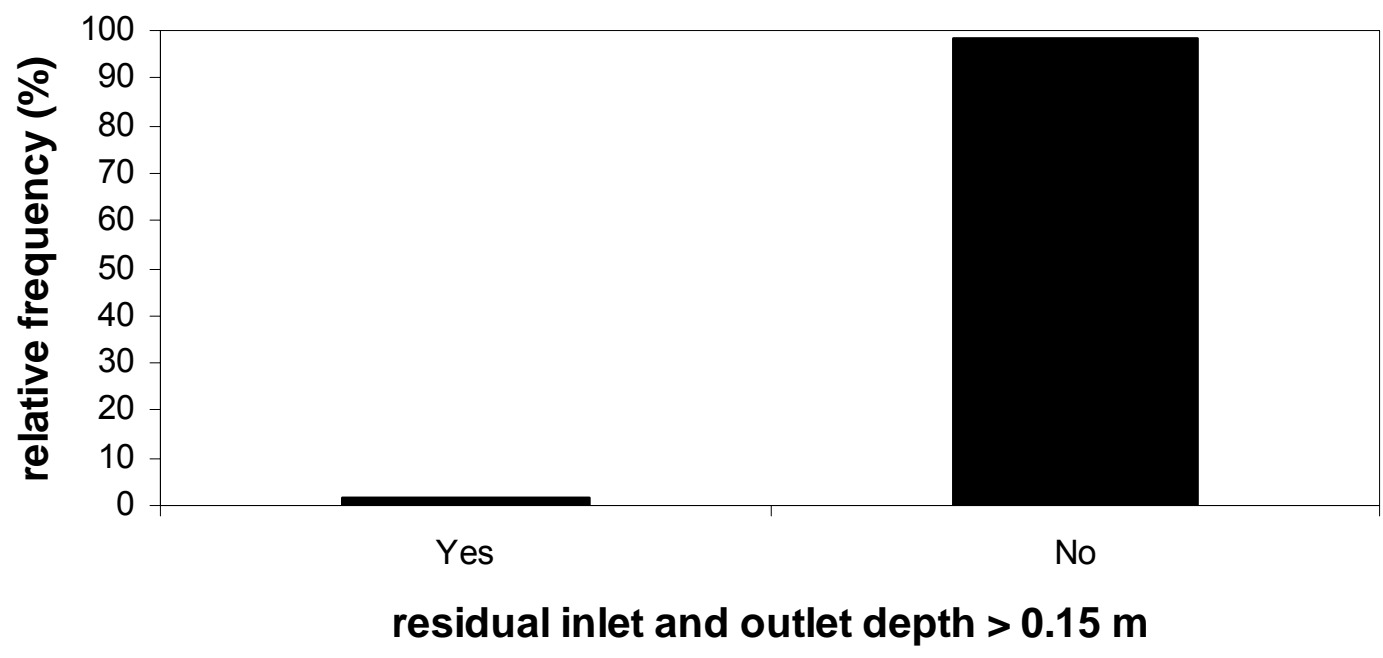

Figure 11: Proportion of culverts within each fish passage category that had a residual inlet or outlet depth of less than $0.15 \mathrm{~m}$. Green culverts are completely passable, gray culverts are partially impassable, and red culverts are completely impassable.

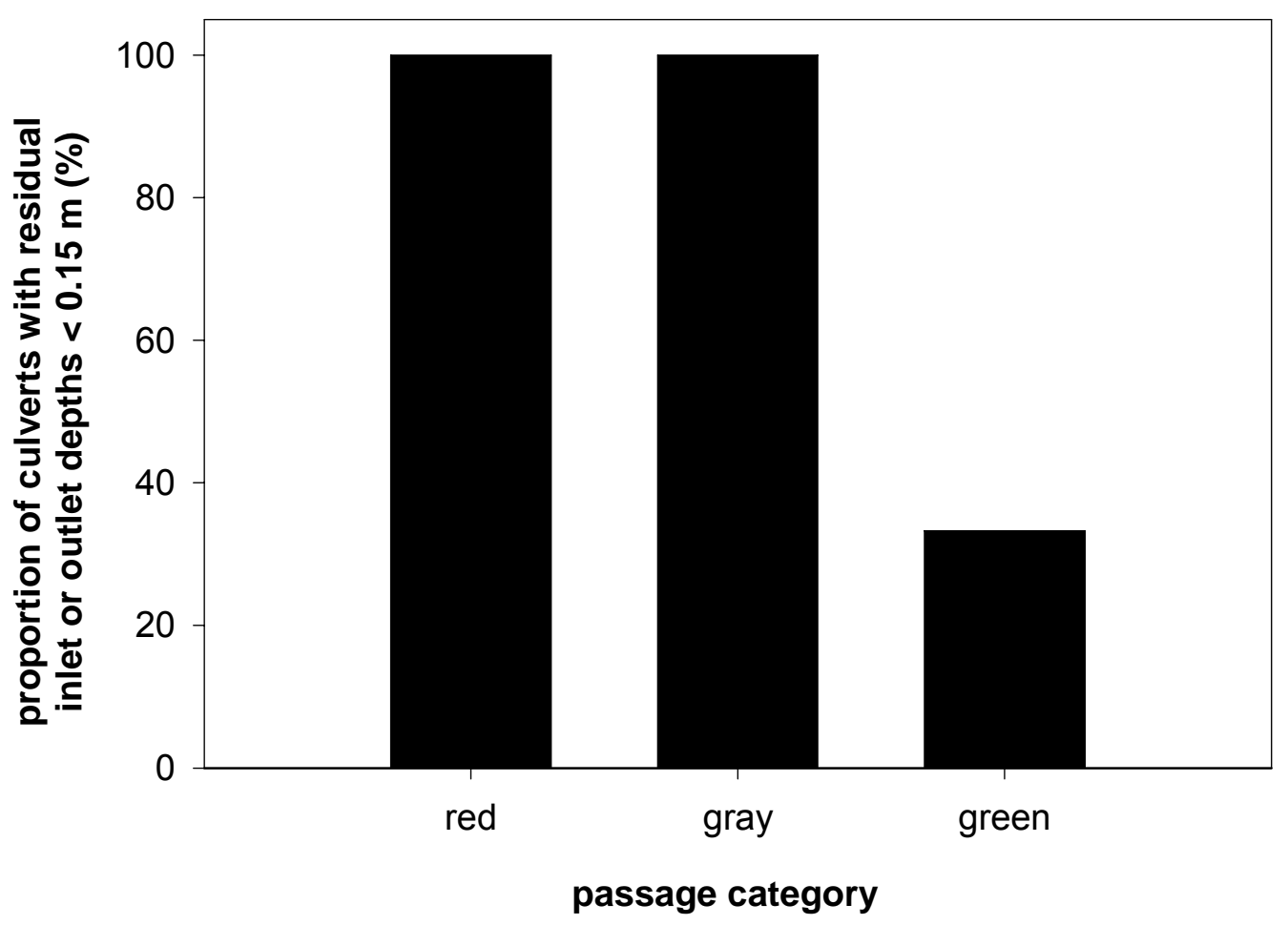


Figure 12: a) Histogram showing inlet width-average active channel width ratio for all culverts surveyed $(n=120)$. b) Relative cumulative frequency of inlet width-active channel width ratios for all culverts surveyed. A majority of culverts (77\%) had inlets that were narrower than the average active channel width.

$\mathrm{a}$

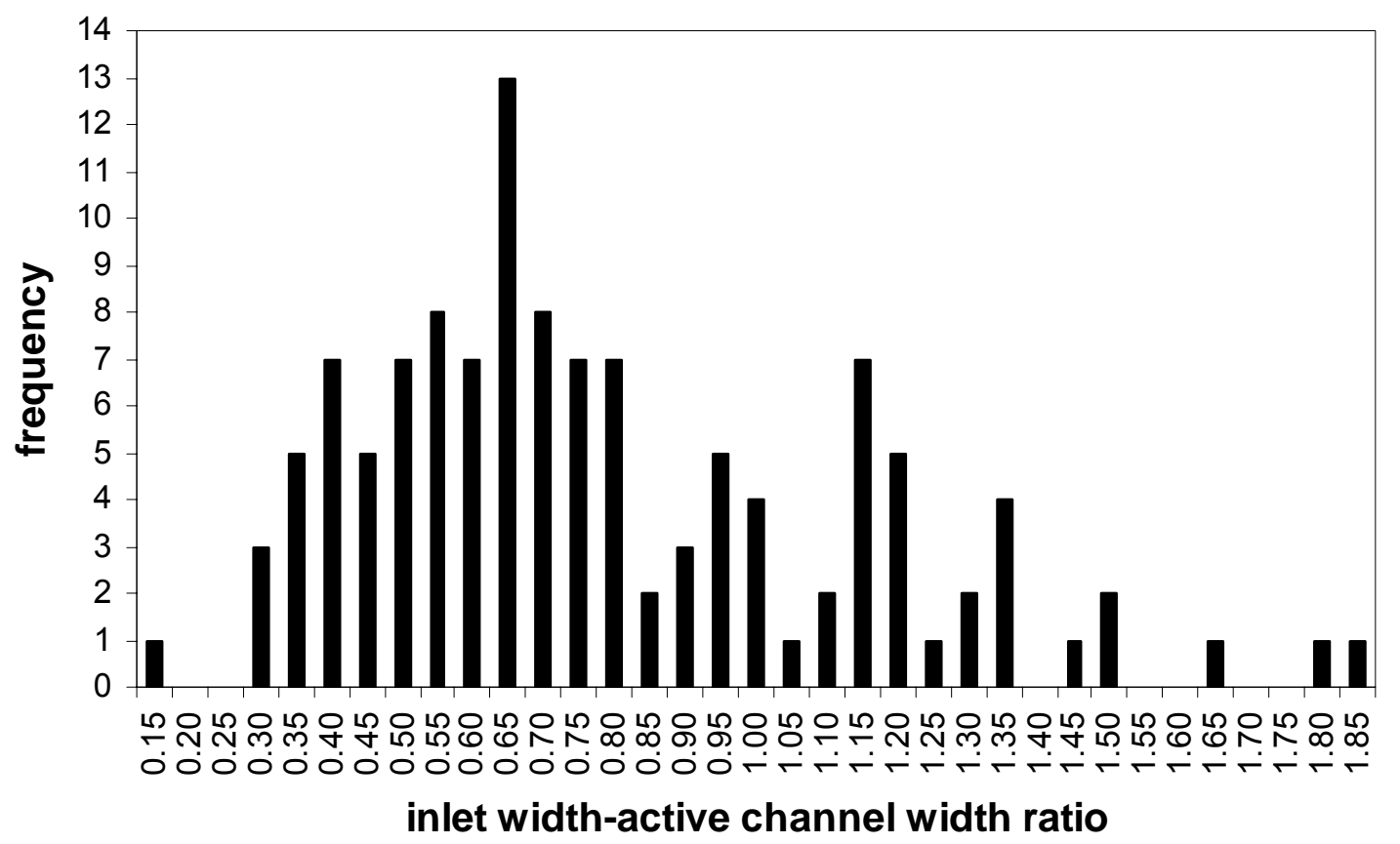

b

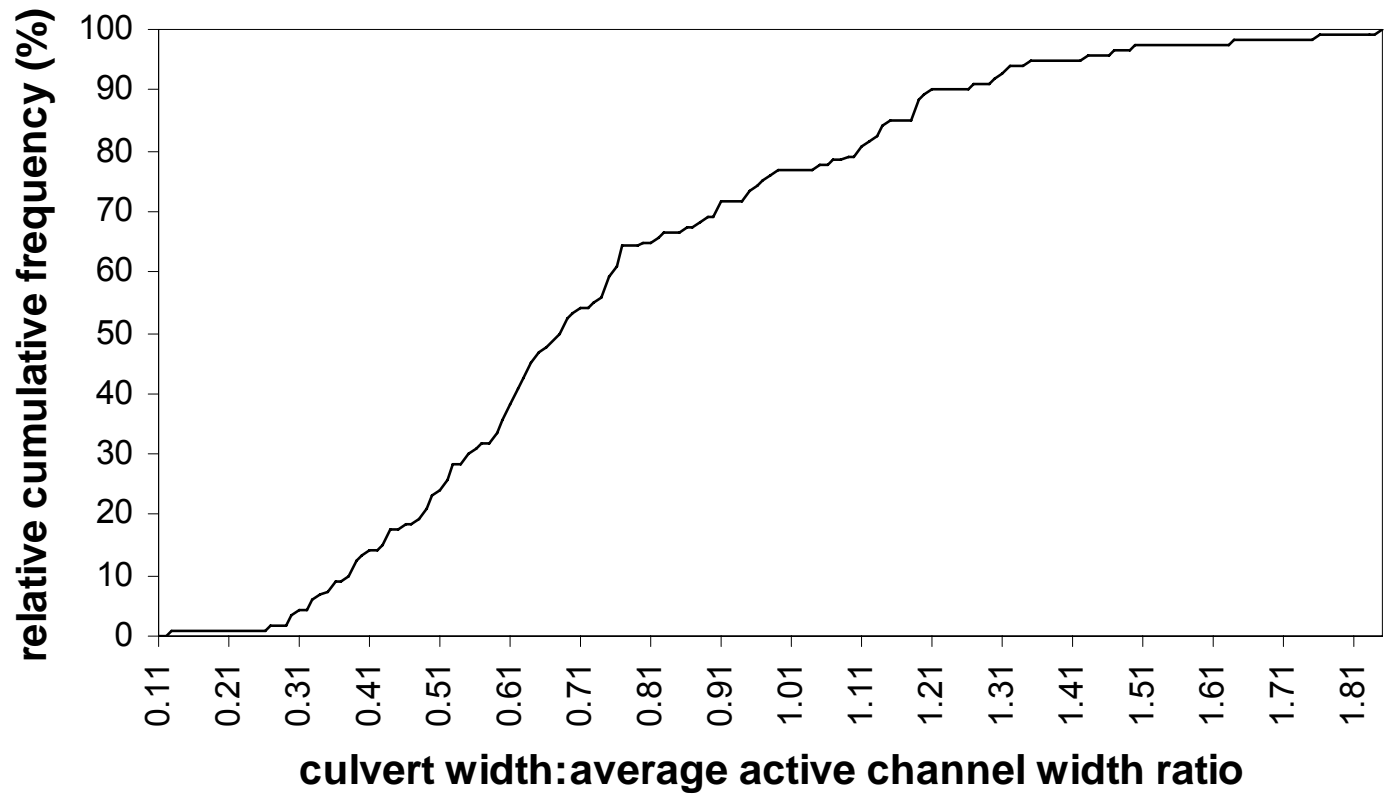


Figure 13: a) Histogram showing outlet hang height $(m)$ for all culverts surveyed $(n=120)$. b) Relative cumulative frequency of outlet hang height $(\mathrm{m})$ for all culverts surveyed. A majority of culverts (61\%) were hanging and $13 \%$ were hanging over $0.61 \mathrm{~m}$.

a

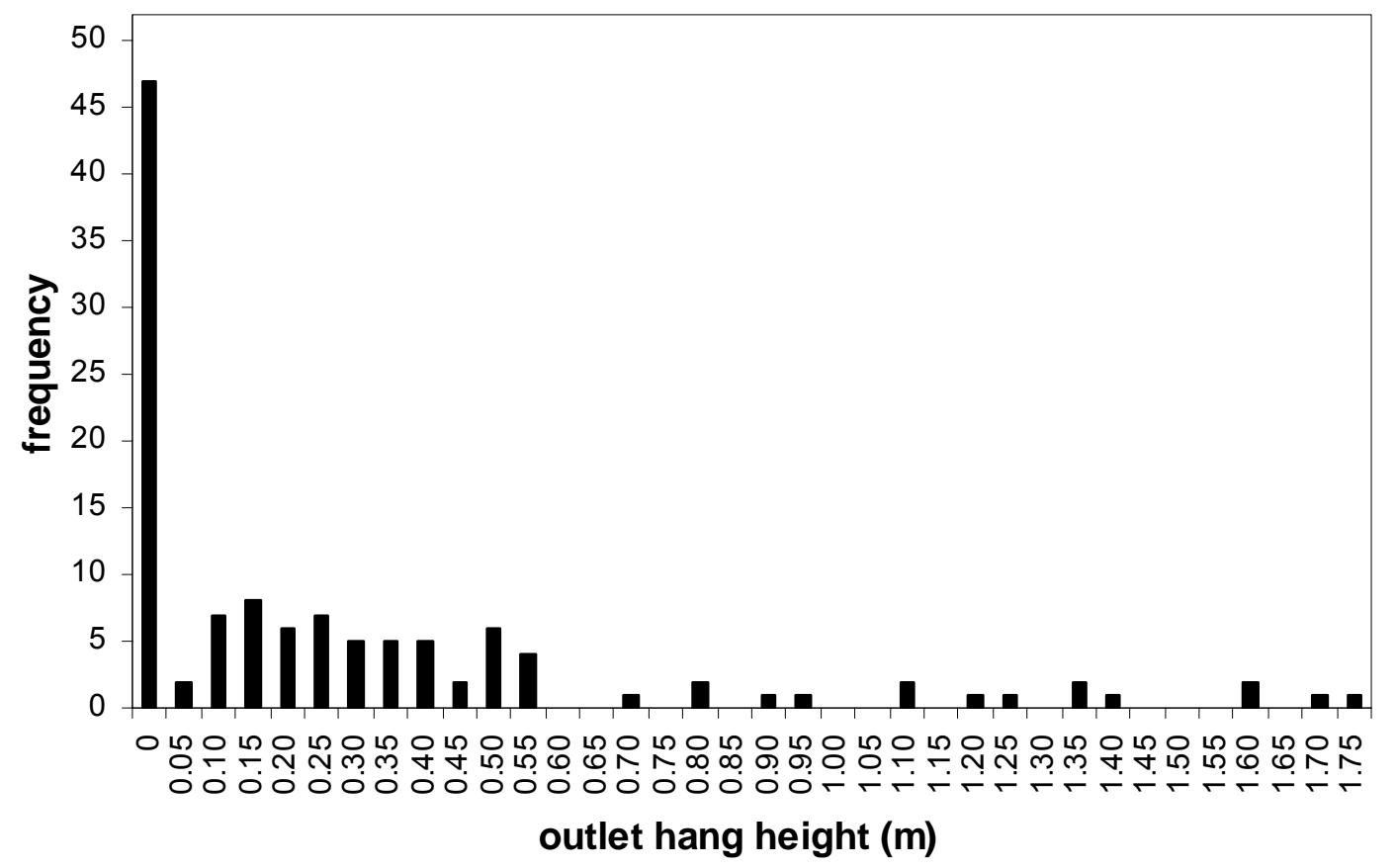

b

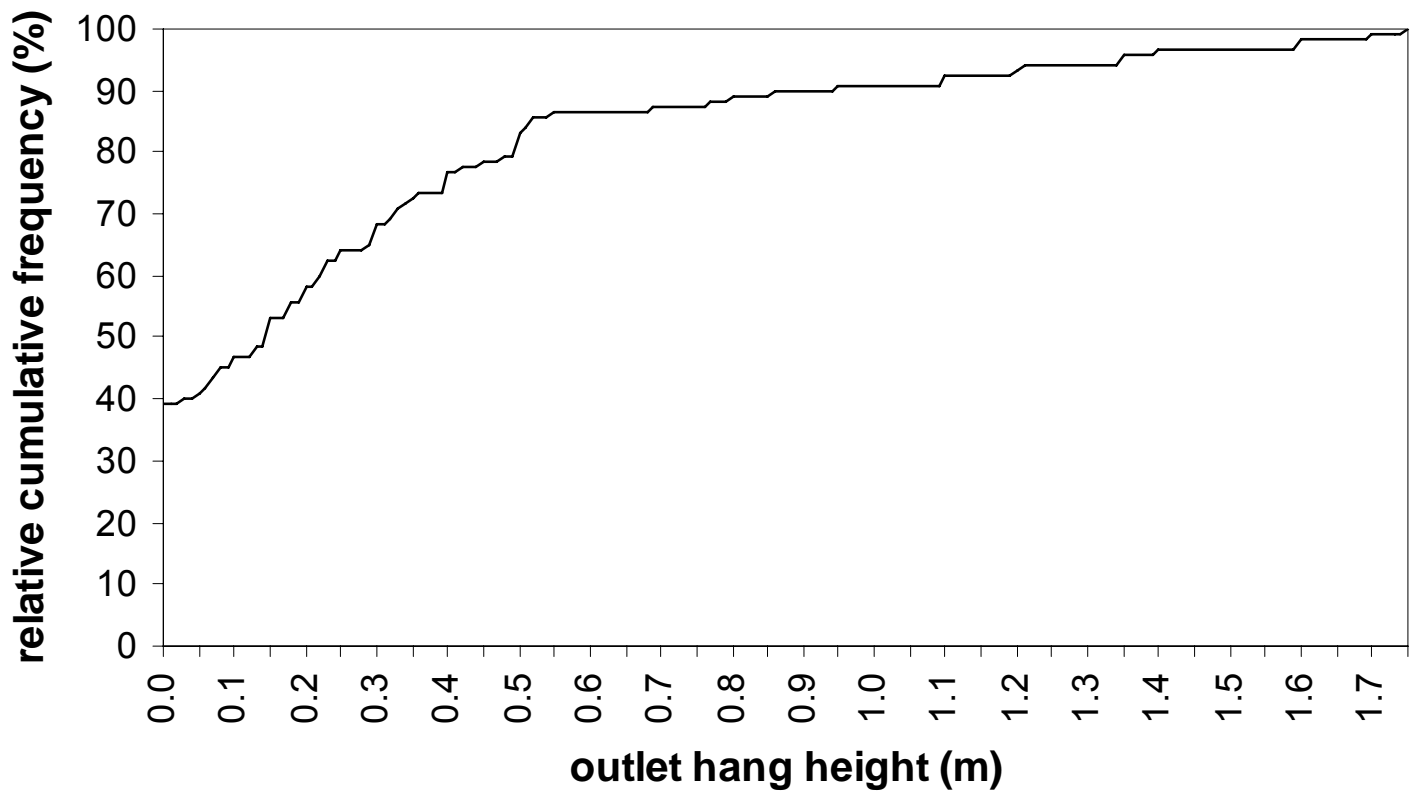


Figure 14: a) Histogram showing culvert slope (\%) for all culverts surveyed $(n=120)$. b) Relative cumulative frequency of culvert slope (\%) for all culverts surveyed. A majority of culverts (68\%) had slopes of over $3 \%$.

a

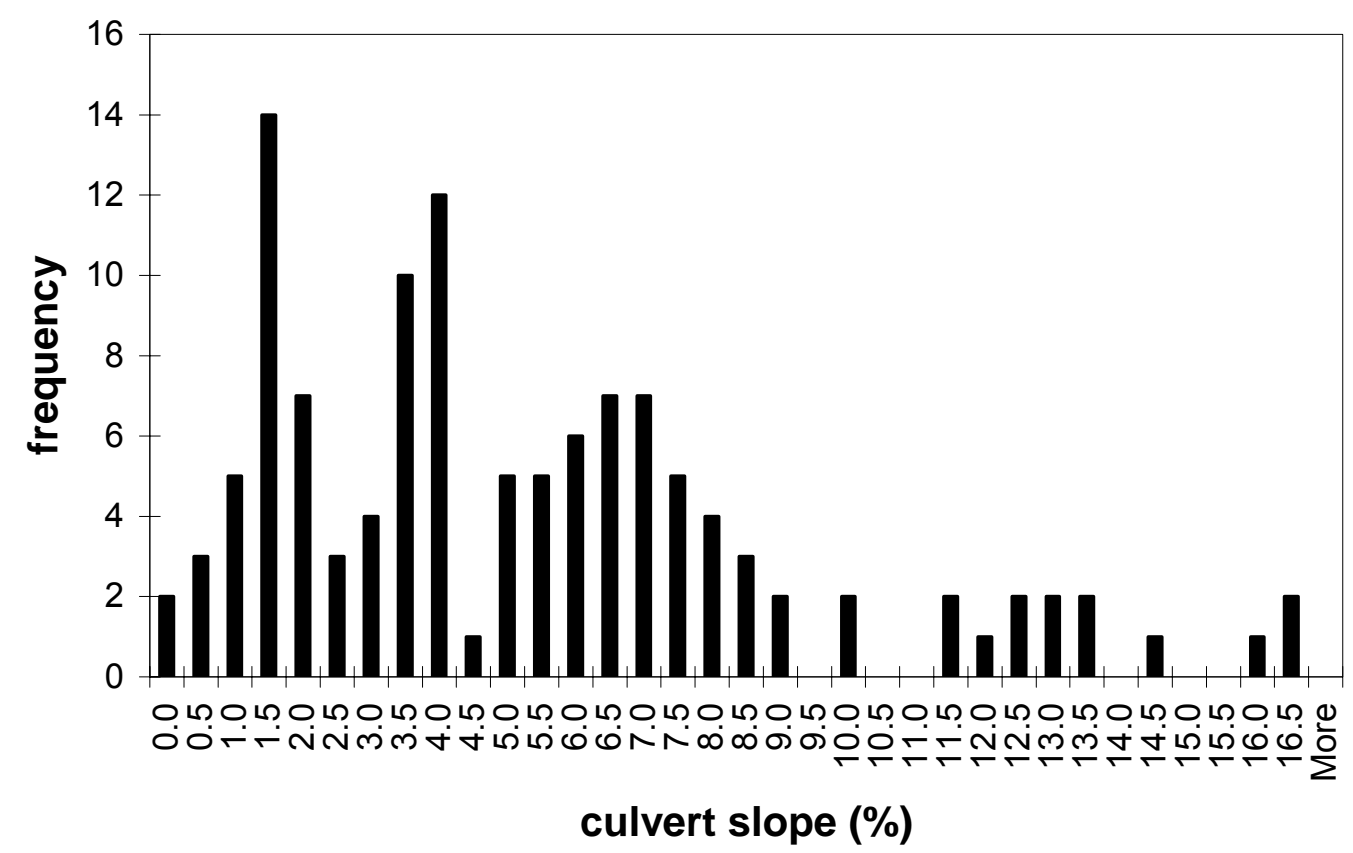

b

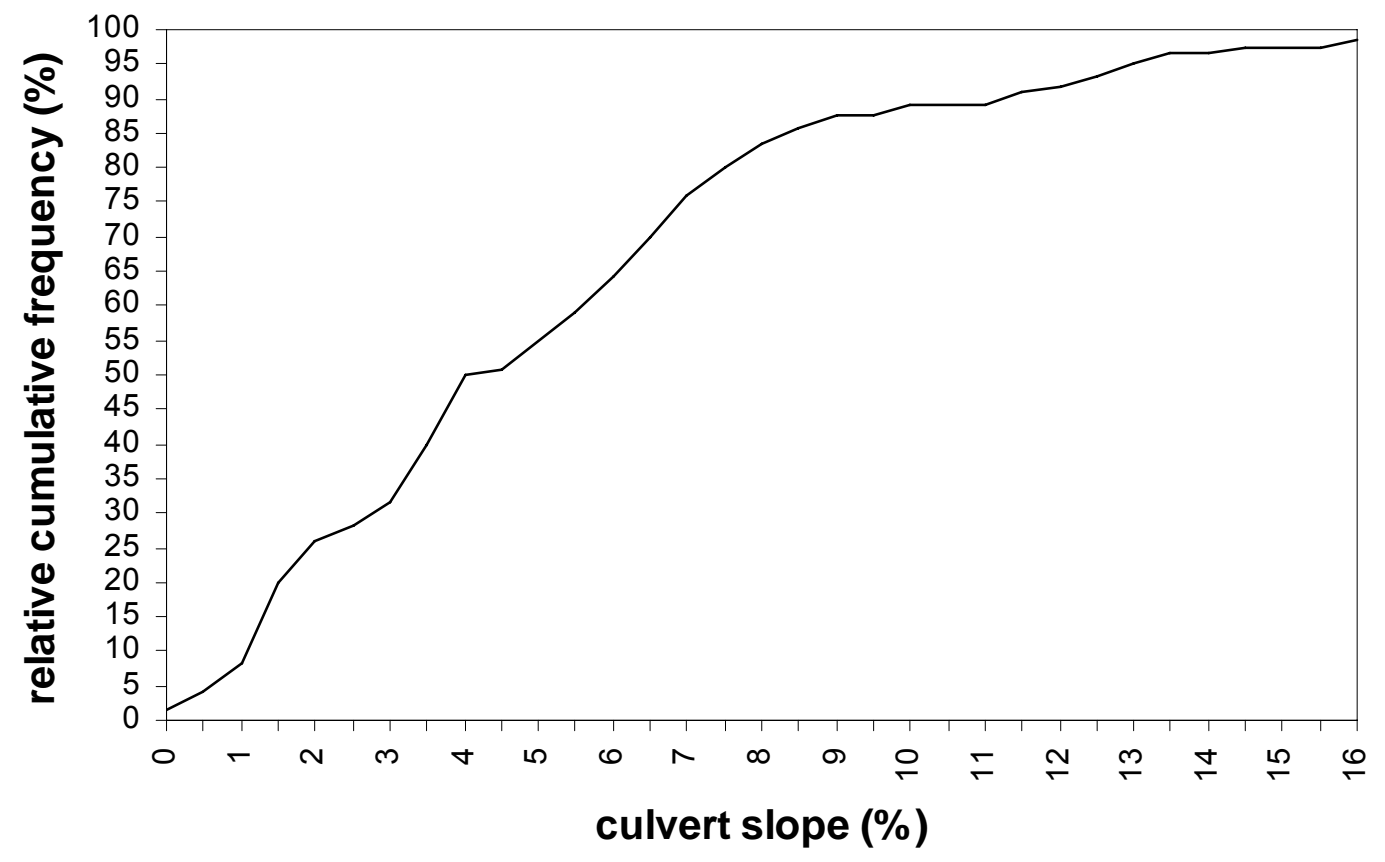


Figure 15: Box plots comparing the following variables between groups of red (completely impassable), gray (partially impassable), and green (completely passable) culverts: a) inlet width-active channel width ratio, b) outlet hang height (m), c) culvert slope (\%), d) survey channel slope (\%), e) basin area at the culvert $\left(\mathrm{km}^{2}\right)$, and f) active channel width (m).
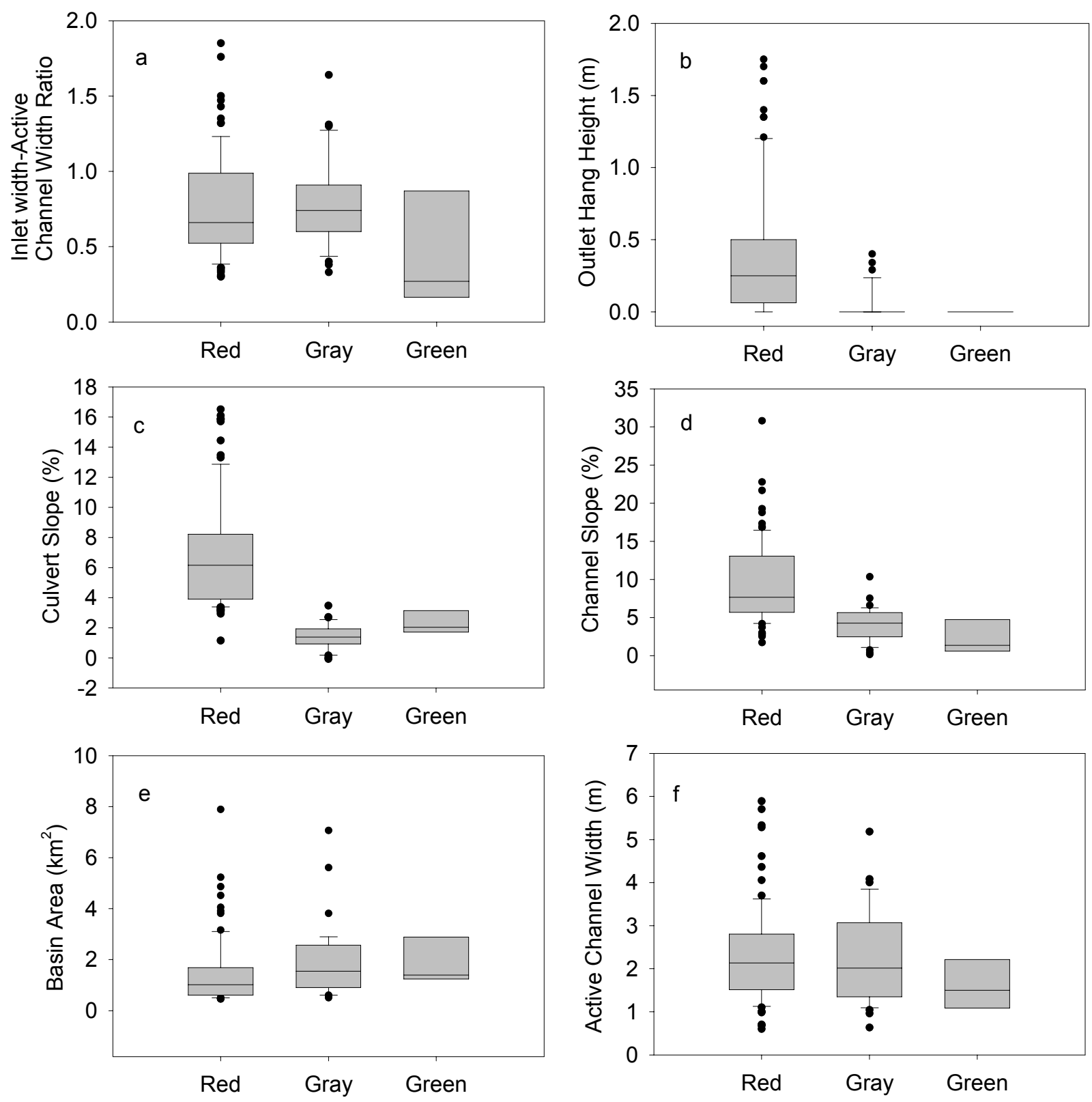
Figure 16: Cumulative proportional occurrence of all culverts as well as red (completely impassable) culverts versus the following variables: a) inlet width-active channel width ratio, b) outlet hang height (m), c) culvert slope (\%), d) survey channel slope (\%), e) basin area at the culvert $\left(\mathrm{km}^{2}\right)$, and $\left.\mathrm{f}\right)$ active channel width (m).
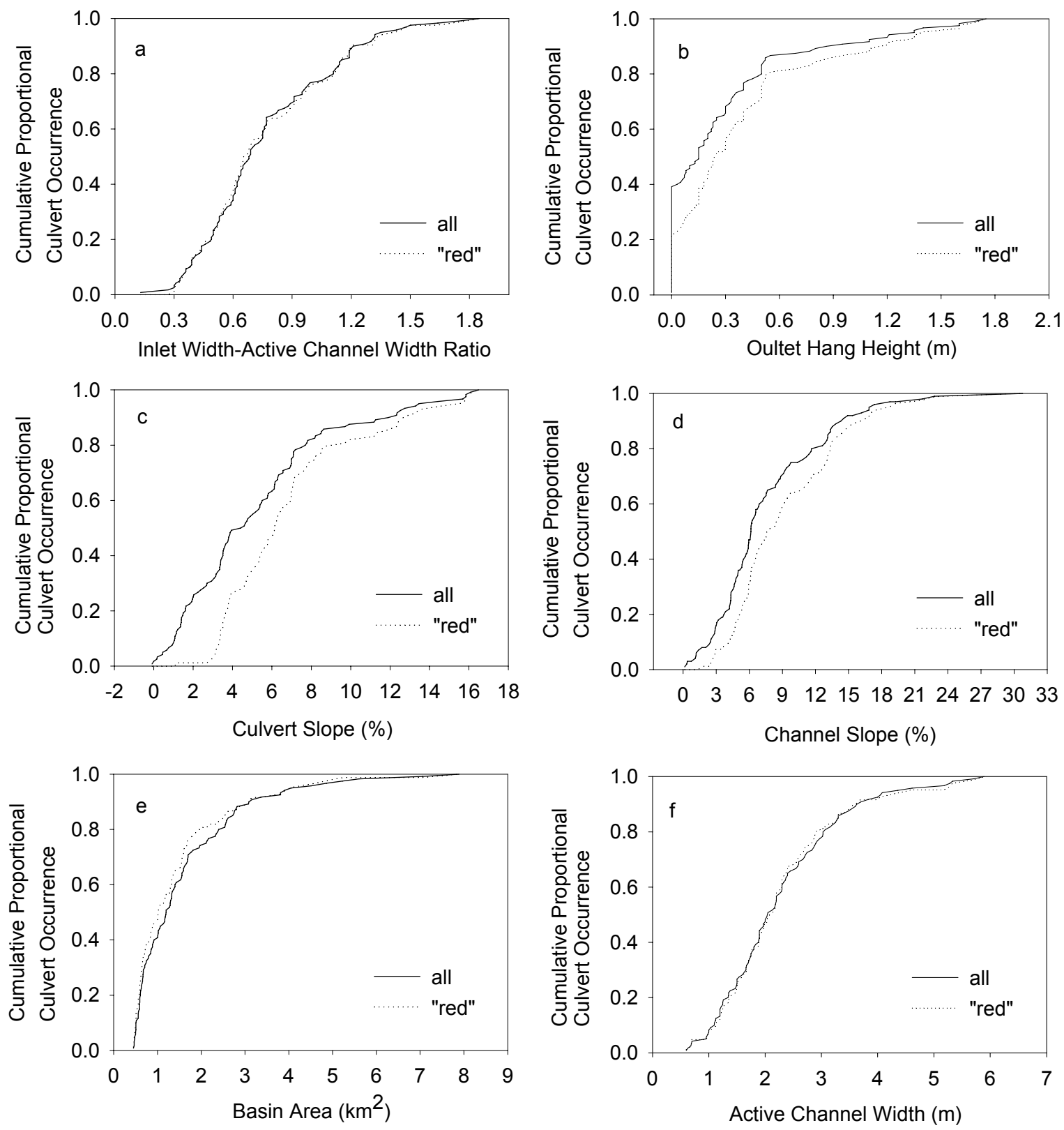
Figure 17: Map of study area highlighting stream segments located upstream of red (completely impassable) culverts. Overall, $144 \mathrm{~km}$ of stream length and $130 \mathrm{~km}$ of weighted potential recruitment area are located above impassable culverts.

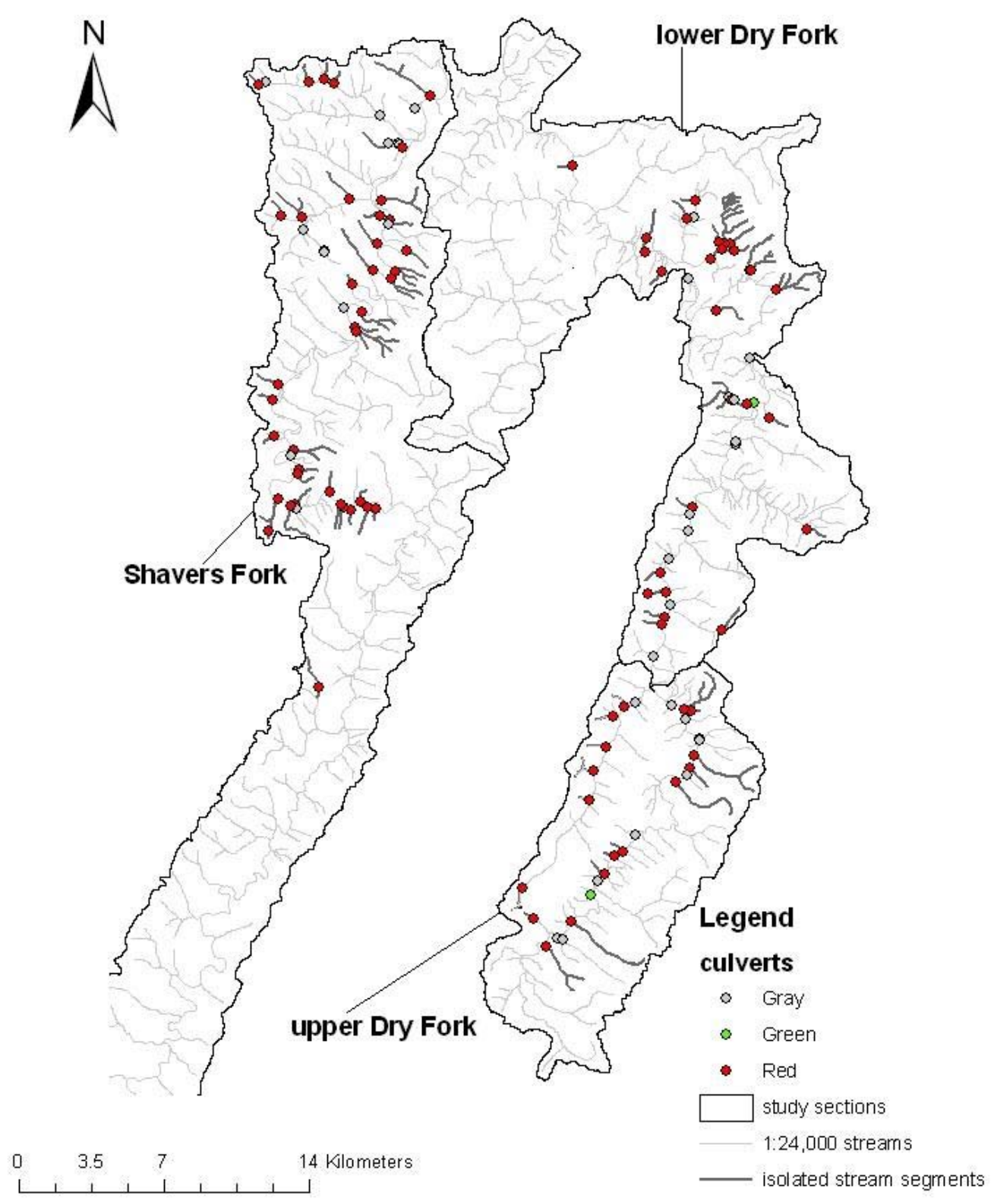


Figure 18: Proportion of the length of stream and weighted potential recruitment area located upstream of red (completely impassable) culverts within each study section as well as within the entire study area.

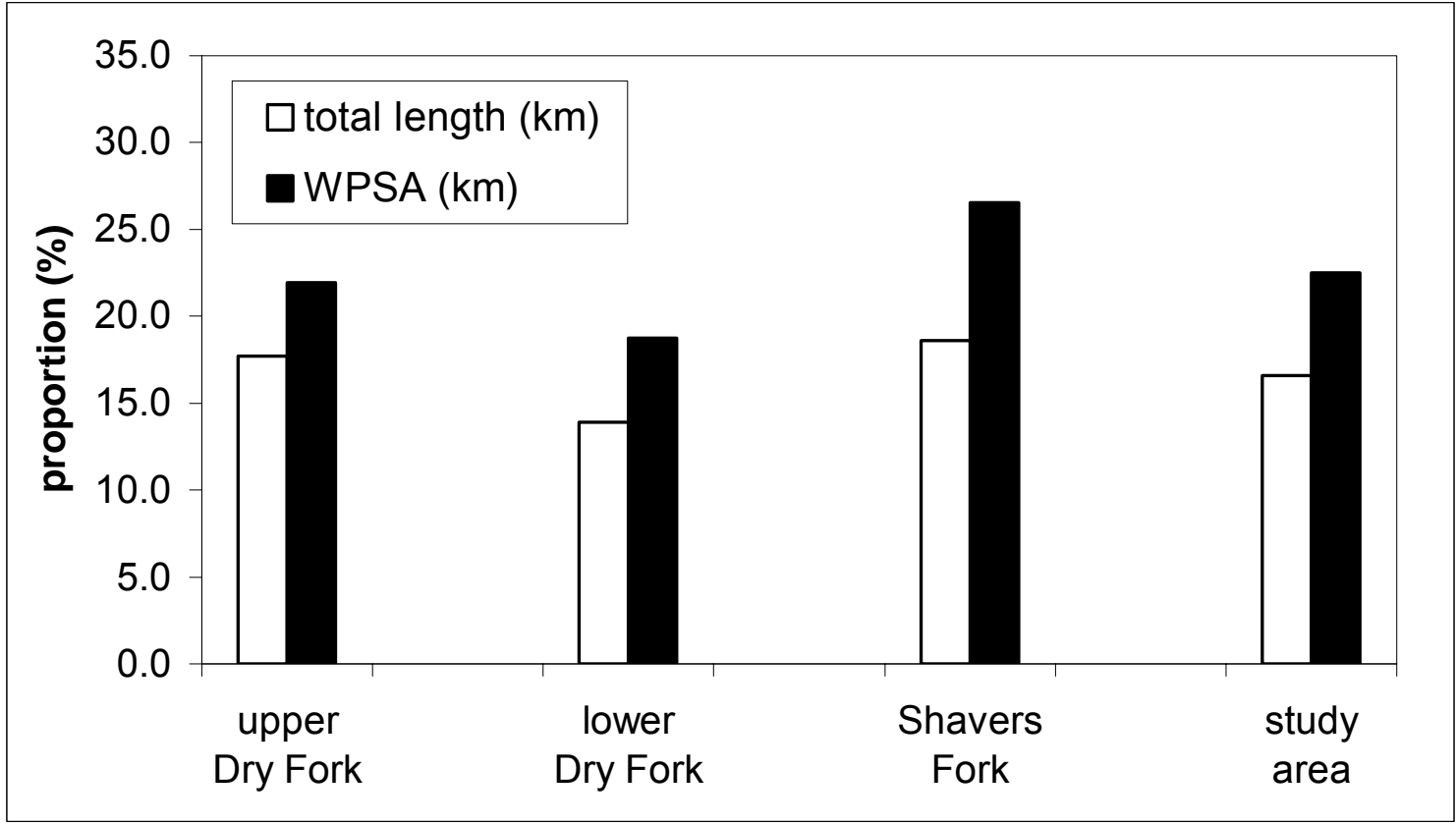

Figure 19: Weighted potential recruitment area (WPRA) loss extent vs. loss intensity due to habitat isolation by red (completely impassable) culverts for each study section within the study area. Shavers Fork had both the highest loss extent and intensity.

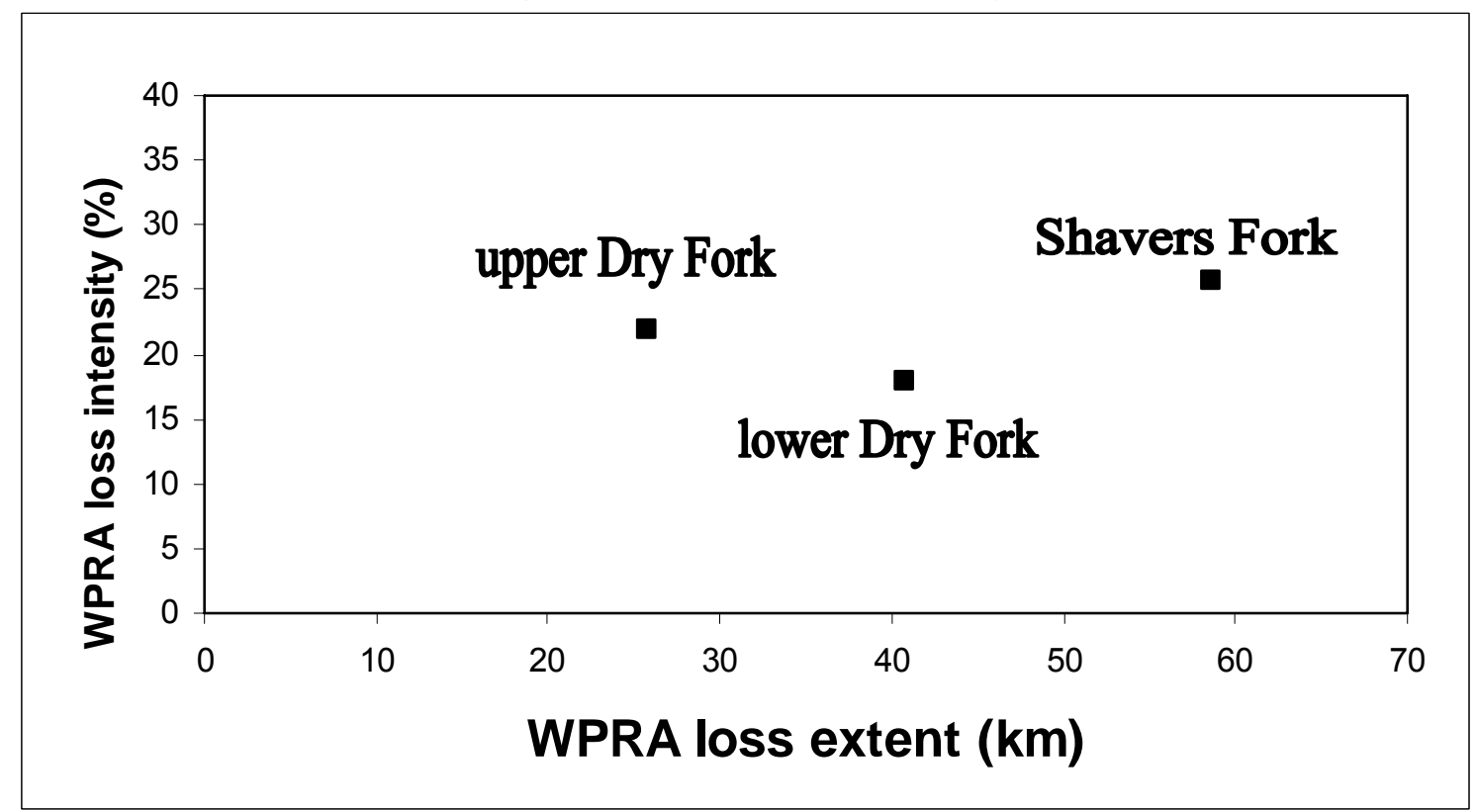




\title{
Chapter 3
}

\section{Culvert Effects on Fish Assemblages in a Central Appalachian Watershed.}

\author{
Abstract \\ Stream crossings have adverse impacts on aquatic ecosystems through habitat loss and \\ degradation, alteration of ecological processes, and effects on individual animals and \\ populations. Culverts, in particular, can act as barriers to the movement of many stream- \\ dwelling organisms, including fishes. Movement is particularly important to stream-dwelling \\ fish that often must move to locate habitats needed to maximize fitness. Many past fish passage \\ studies have focused on the most economically important species, typically the strongest \\ swimmers. Community-based approaches to research addressing culvert impacts are needed. \\ We sampled fish assemblages and several habitat variables within $150 \mathrm{~m}$ stream reaches both \\ above and below 24 culvert road crossings within small streams of the upper Cheat River Basin, \\ West Virginia. We used pairwise Wilcoxon Signed Ranks tests as well as stepwise multiple \\ regression analysis to test whether species richness or species densities were different upstream \\ of culverts compared to downstream and whether differences could be attributed to population \\ isolation upstream of culverts. Overall, we found that mean species richness was significantly \\ lower upstream of culverts $(2.0)$ than downstream $(2.6)(\mathrm{p}=0.014)$ and no richness effect was \\ observed on any stream draining over $3.5 \mathrm{~km}^{2}$. Additionally, we found that blacknose dace \\ (Rhinichthys atratulus) densities were significantly lower upstream of culverts (8.2 \\ individuals/100 m) than downstream (12.1 individuals/100 m) $(\mathrm{p}=0.011)$. Brook trout \\ (Salvelinus fontinalis) were apparently unimpacted by culverts at the scale of our study. The \\ difference in richness could be attributed to either the isolation of populations above culverts or a \\ combined isolation-channel gradient effect where culvert isolation had more impact where
}


stream slopes are higher upstream of the culvert. Differences in blacknose dace densities could be attributed to a culvert-isolation effect only. Moreover, we found that pairwise differences in richness (downstream-upstream) were positively correlated with stream distance of the culvert from the mainstem (nearest point draining $15 \mathrm{~km}^{2}$ ) and negatively correlated with longitudinal variation in average flow velocity. Finally, we found that culvert effects are more pronounced on species whose core ranges are limited to larger streams compared to species who range into smaller streams. These findings underscore the importance and vulnerability of headwater stream ecosystems and show that culvert isolation, among other impacts, has negatively impacted fish communities within the Cheat River basin. However, because impacts are greatest on ubiquitous species and large stream species but culvert effects are greatest on small, steep, streams, we feel that culvert-related restoration efforts will not have as much overall benefit to fish assemblages in the Cheat River basin as the remediation of more extensive problems, such as acid deposition. Additionally, these results show that fish passage standards should consider whole communities.

\section{Introduction}

The U.S. Department of Transportation (2003) reported that 13,435,118 km of road lanes permeate the United States and Puerto Rico. According to Forman (2000), roads and roadsides cover about $1 \%$ of the land in the U.S., an area equivalent in size to South Carolina (Forman 1995). In general, biotic integrity in both terrestrial and aquatic ecosystems is negatively affected by roads (Trombulak and Frissell 2000). The ecological effects of roads vary in distance outward from meters to kilometers (Forman 1995). Forman (2000) estimated that $19 \%$ of the total area of the United States is directly affected ecologically by roads and vehicular traffic. There are seven general ways that roads can affect terrestrial and aquatic ecosystems: (1) 
increased mortality from road construction, (2) increased mortality from collision with vehicles, (3) modification of animal behavior, (4) alteration of the physical environment, (5) alteration of the chemical environment, (6) spread of exotic species, and (7) increased alteration and use of habitats by humans (Trombulak and Frissell 2000).

Stream crossings, including culverts, have particularly adverse impacts on aquatic ecosystems through habitat loss and degradation, alteration of ecological processes, and effects on individual animals and populations. In general, culvert crossings provide little habitat for stream-dwelling organisms. The replacement of natural streambed and banks with road crossing structures usually results in the loss of habitat value. Various benthic organisms are confined to the streambed and can only move through these substrates. Discontinuities in the streambed can fragment populations and potentially reduce genetic diversity, limit access to critical habitats, and prevent recolonization of habitats after catastrophic events. These effects may be avoided if culverts are sufficiently embedded under the natural substrate or if open-bottom or arch culverts are used. These types of culverts often maintain natural substrate (Jackson 2003). However, studies show that most culverts do not contain natural streambed substrate resulting in the upstream isolation of habitat. For example Ward (2005) found that over $84 \%$ of culverts surveyed in the Dry Fork and Shavers Fork drainages within the upper Cheat River basin did not contain continuous streambed substrate. Additionally, $20.6 \%$ of the total stream length in the Dry Fork watershed and $18.4 \%$ in the Shavers Fork watershed were isolated to salamanders by culvert barriers (Ward 2005).

Stream crossings may have adverse impacts on the hydrology and geomorphology of the stream channel. Culverts often constrict the stream channel causing ponding upstream. This may result in the aggradation of stream bed material above the culvert. Moreover, water 
velocities may increase within the culvert barrel resulting in downstream channel scour. This scour often results in a perched culvert that functions as a barrier to animal movement (Jackson 2003). White (2004) found that three-quarters of culverts surveyed within the upper Cheat River basin were undersized and could not convey a bankfull discharge. Culverts that lack conveyance may develop problems with aggradation, blockage, scouring, inlet slackwater and large woody debris blockage (White 2004). Artificial crossing structures also may prevent the transport of woody debris downstream and inhibit the formation of natural debris dams that are important habitat features for many organisms. These features also play a role in shaping channel characteristics (Jackson 2003).

Excess erosion and sedimentation also can occur at artificial crossing structures. High levels of sedimentation may enter the stream through runoff during road construction and can continue over the long term through the erosion of embankments, the road surface, and drainage ways (Beschta 1978; Reid and Dunne 1984; Jackson 2003). Wellman et al. (2000) found that sediment depth and silt-clay percentages were significantly higher directly below recently constructed culverts than in stream reaches upstream of culverts. Both sediment depth and siltclay percentages were higher at culverted streams than at bridged streams (Wellman et al. 2000). There are several ways that sedimentation can impair aquatic ecosystems. Fine sediments can fill interstitial spaces within the streambed substrate and impact populations of macroinvertebrates and other benthic organisms that depend on these interstitial spaces for habitat (Wood and Armitage 1997). Increased sediment loading can negatively impact fish populations through reductions in the availability and permeability of suitable spawning gravel (Davies and Nelson 1993; Hartman et al. 1996) and the reduction of predation success of visual predators due to increases in turbidity (e.g. Sweka and Hartman 2001). In addition to sediment, 
stormwater runoff from roads also may contain toxic contaminants that alter the chemical environment (Trombulak and Frissell 2000; Jackson 2003).

Additionally, culverts can act as barriers to the movement of many stream-dwelling organisms, including fish (e.g. Warren and Pardew 1998). These movements are important ecological processes in most systems. Movement is particularly important to stream dwelling fish populations, especially in physically heterogeneous streams, where fish must often move to locate habitats needed to maximize fitness (Faush and Young 1995). Such movements are often critical for individuals to complete their life cycles and for metapopulations to remain viable (Schlosser and Angermeier 1995). Many stream-resident fish need to move in order to locate suitable spawning areas (e.g. Hunt 1974; Petty et al. 2005), thermal refugia (e.g. Kaeding 1996), refuge from predators (e.g. Harvey 1991), foraging areas (e.g. Clapp et al. 1990), and habitats suitable for the completion of various life-history stages (e.g. nursery habitat for juveniles, Johnston 1997). At the population level movement is critical to the recolonization of decimated stream reaches and the maintenance of genetic diversity between subpopulations (Jackson 2003). Additionally, fish movement and influences on movement (e.g. population size structure, stream flow, distribution of critical habitats) hold important consequences for population regulation and dynamics (e.g. Petty and Grossman 2004).

Culverts act as barriers to fish movement in the following ways: excess drop at the culvert outlet, high water velocity within the culvert barrel, inadequate water depth within the culvert barrel, turbulence within the culvert, and debris and sediment accumulation at the culvert inlet or internally. Culvert barrels are usually designed to optimize water passage and they do not have the necessary roughness and complexity needed to reduce flow velocity. Instead, culverts tend to concentrate and dissipate energy in the form of increased velocity beyond the 
swimming capabilities of most fish species. Turbulence or downstream channel scour are the most prevalent blockages at culverts (Bates et al. 2003).

Angermeier et al. (2004) proposed a conceptual framework for assessing the impacts of roads on aquatic biota. This framework was developed to aid environmental managers in assessing the full range of environmental impacts of road building projects on aquatic ecosystems. Most conventional environmental assessments of roads focus on construction impacts but overlook subsequent impacts. These authors suggested that there are three main phases of road development, each with a distinctive suite of environmental impacts: road construction, road presence, and urbanization (Angermeier et al. 2004).

The environmental impacts of road construction (phase 1) are characterized by relatively small temporal and spatial frames. These impacts largely stem from direct, localized, and acute alterations of physical conditions (e.g. fluxes of fine sediments, stream channelization, and disruption of groundwater flow) (Angermeier et al. 2004). Phase 2, road presence, affects aquatic systems over similar spatial frames but across larger temporal frames compared to road construction. These longer timeframes stem from the fact that roads are rarely restored to natural habitat. Environmental impacts of road presence are physical (e.g. short-term effects of intermittent road maintenance and long-term alterations in hydrology and geomorphology), chemical (e.g. toxic runoff from road surfaces and toxic spills), and biological (e.g. the spread of invasive species and fragmentation of aquatic habitats). These authors stated that the biological consequences of road presence, including culvert barrier effects on fish populations and communities, are poorly documented (Angermeier et al. 2004).

Urbanization (phase 3) affects aquatic ecosystems over large spatial and temporal frames and may lag behind road construction for decades. Due to this lag, urbanization is often 
excluded from environmental impact assessments (Angermeier et al. 2004) even though it is the second-leading cause of species imperilment in the U.S., next to non-native species (Czech et al. 2000). Physical and chemical effects of urbanization overlap those of construction and presence, but are more severe because of greater road densities, more construction, more vehicular traffic, proliferation of impervious surfaces, removal of woody debris and riparian vegetation, and stream channelization. These changes strongly influence aquatic biota (Angermeier et al. 2004). Moreover, in recent years there has been a call for holistic, interdisciplinary approaches to culvert design and replacement that focus on community and ecosystem-oriented goals (Sylte 2002; Jackson 2003). In the past, fish passage concerns tended to focus on adult salmon and trout (Sylte 2002), and typically the most attention was given to the passage of migratory species (Jackson 2003). In most ecosystems these migratory species are the strongest swimmers. Even if culverts are adequate for the passage of these species they may not be adequate for the passage of other species within the community. Therefore, community-based approaches to fish passage design and research addressing culvert effects are needed. Angermeier et al. (2004) called to ecologists to conduct and publish studies that demonstrate road impacts on aquatic biota at the individual, population, and community levels of organization.

Fish communties in the Cheat River Basin are impacted by various anthropogenic factors. The northern (downstream) end of the watershed is extensively impaired by acid mine drainage (WV DEP 1996; Petty and Barker 2004) which is believed to be the largest water quality problem in the watershed (WV DEP 1996). Additionally, within the Northern half of the watershed there is a power plant located on the mainstem of the river which raises water temperatures an average of $17^{\circ} \mathrm{F}$. There is also a $17 \mathrm{~km}$ long impoundment, Cheat Lake. The Southern half of the watershed is considered to be healthy, although there are some tributaries 
that are impacted by sediment, fecal coliform, acid mine drainage, and acid precipitation. These conditions impact both the diversity and abundance of fish communities throughout the basin (WV DEP 1996). Brook trout, in particular, have suffered marked declines within sections of the basin, most notably in Shavers Fork, and represent an economically important regional fishery. Acidification, fishing pressure, sedimentation, and loss of riparian vegetation have all contributed to this fisheries' decline (Petty et al. 2001; Petty and Thorne 2005; Petty et al. 2005). In addition to these factors, the Cheat River basin is characterized by a dense network of roads and culvert road crossings are a common occurrence. It is likely that the presence of culvert crossings have negatively impacted stream fish communities within the Cheat River basin.

The first objective of this study was to assess the impact of long-term culvert presence on stream-fish communities within the upper Cheat River basin, West Virginia. We hypothesized that species diversity and population densities of weaker swimming species would be reduced above culverts due to the long-term isolation of stream habitat. Moreover, we expected that species whose core distributions extended upstream to small streams would be less impacted by culverts than species whose core distributions are limited to larger streams. Our second objective was to identify any physical characteristics (e.g. basin area or channel slope) within our study streams that might be related to culvert barrier effects.

\section{Study Area}

The upper Cheat River basin is located in Randolph and Tucker Counties, West Virginia, and consists of all water draining to the confluence of Black Fork and Shavers Fork near the town of Parsons. These two rivers form the Cheat River, a major tributary to the Monongahela River. Black Fork is formed at the confluence of Dry Fork and the Blackwater River $6.4 \mathrm{~km}$ upstream of the Shavers Fork-Black Fork confluence. We studied 47 culverts located within 
three watersheds of this basin: lower Dry Fork ( $6^{\text {th }}$ order), Glady Fork, and upper Dry Fork (Figure 20). Glady Fork is a 4th order stream that empties into Dry Fork $16.4 \mathrm{~km}$ upstream of the Blackwater River. The upper Dry Fork includes all water draining to the confluence of Gandy Creek ( $4^{\text {th }}$ order) and Dry Fork, above Gandy Creek, $\left(3^{\text {th }}\right.$ order) located $33.0 \mathrm{~km}$ upstream the Blackwater River confluence.

The upper Cheat River basin ranges in elevation from 494 to $1476 \mathrm{~m}$. Other general physical characteristics are listed by watershed in Table 5. Both Randolph and Tucker Counties are characterized by humid-temperate climates. Winters are cold and snowy at high elevations and valleys also are cold and snowy but have intermittent thaws. Summers are mildly warm at high elevations and very warm with the occasional very hot day in the valleys. The average annual temperature is $9.7^{\circ} \mathrm{C}$ in Randolph County (Pyle et al. 1982) and $9.4^{\circ} \mathrm{C}$ in Tucker County (Losche and Beverage 1967). Mean annual precipitation in Randolph County is $107 \mathrm{~cm}$ and 55 \% of this precipitation usually falls between April and September (Pyle et al. 1982). Mean annual precipitation in Tucker County is $135 \mathrm{~cm}$ (Losche and Beverage 1967).

\section{Methods}

\section{Site Selection}

We used a stratified random sampling method for culvert site selection. Forty-seven culverts (Figure 20) located on streams ranging in basin area from 0.4 to $12.5 \mathrm{~km}^{2}$ were assigned random numbers, sorted, and chosen evenly across stream sizes. Culverts sites were not sampled if: 1) the stream was degraded by poor water quality (2002 West Virginia 303d List of Impaired Waters), 2) the stream drained less than $0.44 \mathrm{~km}^{2}$ (100 acres), 3) there was an insufficient stream length upstream of the culvert for a sample reach because of a major confluence or the presence of another culvert, 4) the culvert was located on private property (we sampled only state and 
forest service culverts), or 5) landowner permission was not acquired for stream access.

Additionally, sampling was not performed downstream of the culvert in the case that there was insufficient stream length to sample at least $50 \mathrm{~m}$ of stream before a major confluence. In the end, we sampled both upstream (above the culvert) and downstream (i.e. below the culvert) of 24 culverts (above-below sites) and upstream-only at 23 culverts (i.e. above-only sites).

\section{Data collection}

Water quality, habitat, and fish abundance data were collected within $150 \mathrm{~m}$ reaches located $50 \mathrm{~m}$ above and $50 \mathrm{~m}$ below (where applicable) each culvert (Figure 21). Initially, we set reach lengths at 35 times mean stream width (MSW) according to the recommendations of Simonson et al. (1994). However, many of the streams sampled were so narrow that we believed the reaches would have been too small to adequately represent all habitats, so we set a minimum reach length of $150 \mathrm{~m}$. Upstream and downstream reaches at the same culvert were always sampled on the same day.

There were seven above-below sites where we sampled downstream of the culvert, but we were not able to sample the full $150 \mathrm{~m}$. These reaches were cut short because of a major confluence downstream. We sampled $50 \mathrm{~m}$ reaches below three of these culverts, $65 \mathrm{~m}$ below one, $90 \mathrm{~m}$ below one, $125 \mathrm{~m}$ below one, and $130 \mathrm{~m}$ below one. We do not believe that shorter downstream reaches biased fish samples toward supporting our hypotheses. In fact, shorter downstream reaches actually should result in conservative estimates of species richness and species density data and, if anything, this would bias our results against supporting our hypotheses.

Fish sampling was conducted once per reach between June 1 and July 31, 2004. We used single-pass electrofishing with a seine as a blocknet to sample fish communities. We used 
single-pass sampling instead of triple-pass sampling to maximize the number of sites we were able to sample and to follow standard community sampling procedures used by the EPA (e.g. McCormick et al. 2001). However, to ensure constant sampling efficiency, triple-pass sampling was performed on a subset of stream reaches. This subset included nine reaches from this study and many others within our study area. We found that in Cheat River basin streams draining under $8 \mathrm{~km}^{2}$ (major majority of streams in this study were under this size), capture probabilities on the first pass were high for all fish species (Table 6). Mottled sculpin had the lowest capture probability $(\mathrm{p}=0.53)$. However in streams draining under $1.5 \mathrm{~km}^{2}$ (still a majority of streams in this study) mottled sculpin capture probability increased to 0.60 . Futhermore, we were careful to use the same amount of sampling effort on every stream reach and capture probabilities did not differ between above culvert and below culvert reaches (Petty, J.T., unpublished data).

We used a Smith-Root (Vancouver, Washington) electrofishing unit (DC current, 60 hz, 400-600 V) to perform all electrofishing. Each fish was identified to species and measured for standard length (mm) and weight (g). Several individuals of each species sampled were preserved as reference specimens and field-identification accuracy was later confirmed in the laboratory. Species richness was then calculated for each reach and a population density (\# individuals $/ 100 \mathrm{~m}^{2}$ ) was calculated for each species sampled within each reach by dividing the number of individuals sampled by the area of stream sampled (area = MSW x reach length).

We collected water quality data on two separate occasions at each reach, once in April and once in September, 2004. The water quality variables that we collected included $\mathrm{pH}$, specific conductivity, total hardness, calcium hardness, and alkalinity. Both $\mathrm{pH}$ and specific conductivity were collected with a 600 XL Multi-Parameter Water Quality Monitor (YSI Incorporated, Yellow Springs, Ohio). Alkalinity was measured with a model AL-AP alkalinity 
test kit and total and calcium hardness were measured with a model HA-4P total and calcium hardness test kit (Hach Company, Loveland, CO). These kits are accurate to the nearest 1 grain/gallon (g/g) (17 mg/L) for calcium and total hardness and to the nearest $5 \mathrm{~g} / \mathrm{g}$ (86 mg/L) for alkalinity.

Stream habitat variables were recorded between April 15 and June 16, 2005 within each reach. Several in-stream habitat variables were recorded at evenly spaced points along the thalweg. Thalweg points were spaced every one mean stream width (MSW; Simonson et al. 1994) with a minimum limit set at $2 \mathrm{~m}$. Habitat variables recorded along these transects include water depth $(\mathrm{cm})$, average current velocity (velocity measured at $60 \%$ of the water depth, $\mathrm{m} / \mathrm{s}$ ), bottom current velocity (velocity measured on the streambed substrate, m/s), distance to fish cover (m), and channel unit (riffle, run, pool, or glide). Water depth was measured within the thalweg with a meter stick. Both average and bottom current velocities were measured with a Flo-Mate water velocity meter (Marsh-McBirney Incorporated, Frederick, Maryland). Fish cover was defined as a refuge large enough to hide a $200 \mathrm{~mm}$ fish (Simonson et al. 1994). Distance to cover was measured from the thalweg point to the cover item with a meter stick. All numerical data recorded at thalweg points were averaged for the entire reach. We took the coefficient of variation (CV) of depth and of average current velocity and used these as measures of habitat variability. We calculated a pool-riffle ratio by dividing the number of thalweg points located within a pool section by the number located within a riffle and multiplying by 100 , resulting in a percentage. This value was a measure of how much pool habitat was available for fish to use, compared to riffle habitat.

We also recorded several reach-scale habitat variables on-site that were not part of the thalweg profile. Percent canopy cover was defined as the percentage of sunlight blocked out by 
the forest canopy covering the stream. Canopy cover was collected with a spherical densiometer at 11 evenly spaced thalweg points within each reach (Barbour et al. 1999). At each point, four measurements (facing upstream, downstream, stream left and stream right) were taken and averaged. Those 11 values were then averaged over the entire reach. We conducted EPA rapid visual habitat assessments for high gradient streams within each reach (Barbour et al. 1999). The rapid visual habitat assessment procedure resulted in a value on a scale from 0 to 200 that indicated the relative quality of the stream habitat within a reach.

We then performed a pebble count procedure to characterize the streambed substrate. We modeled our pebble count procedure after the procedure described in Bevenger and King (1995). This procedure consisted of the researcher walking the length of the reach using a zig-zag pattern and selecting pebbles every couple of steps along the way by reaching over the toe of the boot with an extended finger and picking up the first rock that is touched. Pebbles were randomly sampled throughout all channel units and habitat types. Overall, 100 pebbles were sampled over the entire reach. Each pebble was tallied within one of six size classes based upon the diameter of the intermediate axis of the pebble. The size classes were: silt-clay $(<0.062 \mathrm{~mm})$, sand (0.062-1.9 mm), gravel (2-64 mm), cobble (65-256 mm), boulder (257-4000 mm), and bedrock (> $4000 \mathrm{~mm}$ ). Using these data we were able to calculate the percentage of fine sediments (\% silt/sand) within the streambed substrate. This was an important factor because fine sediments are known to impair aquatic ecosystems and have been associated with road building and presence (Wood and Armitage 1997; Wellman et al. 2000). We also were able to calculate a median substrate size $\left(\mathrm{D}_{50}\right)$ for each reach. To find the $\mathrm{D}_{50}$ we first calculated the proportion of pebbles within each size class to the total number of pebbles sampled within the reach. We multiplied this proportion by the geometric mean of the size range defining its class, resulting in 
a weighted proportion. This geometric mean of each size class was defined as the mean of the $\log _{10}$ of the lower end of the size range and the $\log _{10}$ of the upper end of the size range. [e.g. geometric mean cobble $\left.=\left(\log _{10} 64+\log _{10} 256\right) / 2=2.11\right]$. We then took the sum of the weighted proportions of all size classes and set $\mathrm{D}_{50}$ equal to 10 raised to the power of that sum.

Additionally, we tallied large woody debris located within the active channel. All pieces of wood over $1.0 \mathrm{~m}$ in length and $10 \mathrm{~cm}$ in diameter were tallied. Debris under this size are not likely to be fish cover and were not counted. Each piece of debris was tallied within one of 12 size classes based upon diameter and length. We divided length classes into four categories: 1-2 $\mathrm{m},>2-5 \mathrm{~m},>5-10 \mathrm{~m}$, and $>10 \mathrm{~m}$. The three diameter size classes were: $10-20 \mathrm{~cm},>20-30 \mathrm{~cm}$, and $>30 \mathrm{~cm}$. Using these data we were able to calculate the average volume of woody debris per 50 linear meters for each reach. To find this value we first calculated a wood volume to associate with each size class. This was calculated by squaring the mean radius for the diameter size range (e.g. $0.075 \mathrm{~m}$ for the 10-20 cm diameter size range) and multiplying by $\pi$, resulting in the mean cross-sectional area for the size class. We then multiplied this area by the mean of the length size range (e.g. $1.5 \mathrm{~m}$ for the $1-2 \mathrm{~m}$ size range), resulting in a volume $\left(\mathrm{m}^{3}\right)$ values that were associated with each of the 12 size classes. Within each size category we multiplied the associated volume by the number of pieces of wood tallied to arrive at a total volume within each category. Finally, we summed the total volume across all categories resulting in a total LWD volume over the entire reach. We divided this value by the number of $50 \mathrm{~m}$ sections within the reach (reach length/50m) to standardize for reaches of all lengths (large woody debris per $50 \mathrm{~m}$ of stream).

We estimated the pool surface area within each reach by walking the channel and estimating the area of each pool and summing these estimates. Estimation accuracy was ensured 
by actually measuring all of the pools within a subset of reaches and comparing estimated values to measured values. The accuracy of our estimations exceeded $90 \%$. We also divided this value by every $50 \mathrm{~m}$ of reach length to standardize for reaches of all lengths (pool area per $50 \mathrm{~m}$ of stream).

There were a number of variables that we collected within ArcGIS with digital elevation models and linear shapefiles. Basin area at the culvert was calculated with a filled $10 \mathrm{~m}$ digital elevation model developed by the West Virginia University Natural Resource Analysis Center for the entire Cheat River Basin. We used the hydrology model sample extension 1.1 of ArcMap to derive a flow accumulation grid from the digital elevation model. With this flow accumulation grid, the drainage area at any point within the basin could be calculated. We then used the same digital elevation model to calculate the channel gradient (slope) of each reach. Reaches were modeled as segments on a 1:24,000-scale linear stream shapefile for our study area. We used the digital elevation model to calculate the difference in elevation between upstream and downstream ends of each reach. We then divided this difference by the reach length (150 $\mathrm{m}$ in most cases), resulting in a percent gradient. We also calculated the stream length from the downstream end of each reach and from each culvert to the nearest point within the watershed draining at least $15 \mathrm{~km}^{2}$ (distance to mainstem). Stream length was measured along the 1:24,000-scale linear stream shapefile and the FAC was used to find the nearest point draining $15 \mathrm{~km}^{2}$.

\section{Statistical Analysis}

We first performed pairwise wilcoxon signed ranks tests (Wilcoxon 1945) on all abovebelow sites to test for differences in species richness and species densities between upstream and downstream reaches. We used pairwise testing to eliminate variation among streams. This non- 
parametric test was specifically chosen because it is nearly as powerful as the pairwise t-test, but it does not assume data normality, a key assumption that our richness and population density datasets did not meet. Unless otherwise stated, the alpha level on all statistical tests was set at 0.05 .

We then calculated a pairwise difference in species richness between downstream (below the culvert) and upstream (above the culvert) reaches for all 24 above-below sites and we plotted these differences against basin area. We used this plot to identify three groups of culverts: group 1 , culverts crossing small streams (basin area $<3.5 \mathrm{~km}^{2}$ ) where a species richness difference was observed; group 2, culverts crossing small streams where no species richness difference or a negative difference was observed; and group 3, culverts crossing large streams (basin area $\geq 3.5$ $\mathrm{km}^{2}$ ) where no species richness difference was observed (see results). We also identified those species that had significant differences in density between upstream and downstream reaches and calculated a pairwise density difference (downstream - upstream) for all above-below sites. We then plotted these density differences against basin area and identified 2 groups of culverts.

Group 1 included sites where a positive difference in density was observed and group 2 included sites where no difference or a negative difference in density was observed.

Our next task was to identify whether significant effects on fish community variables could be attributed to culvert presence or if culvert effects were confounded with habitat effects and also detect any habitat-dependency of culvert effects. To complete this task we built multiple regression models to identify which habitat variables were most important to the fish community and then identified whether these variables were different between upstream and downstream reaches at sites where culvert effects were observed. We also used principal 
components analysis to identify habitat trends across stream reaches and to use principal components scores representing these habitat trends as variables within our analysis.

Before performing these analyses most habitat variables were $\log _{10}$, $\ln$, or arcsin squareroot transformed to ensure data normality. The arcsin square-root transformation was only used on percentage data. We used the Shapiro-Wilk goodness-of-fit test to assess normality. Water quality variables were excluded from any further analysis since they were not different based upon pairwise tests (Table 7). Additionally, we would not expect water quality to alter community composition between above and below culvert sites. A list of habitat variables and the transformations used for each dataset are listed in Table 8.

A principal components analysis was performed to identify broad habitat trends across all reaches sampled. Additionally, if the principal components scores were determined to be valid and representative, we used them as predictor variables within the multiple regression analysis to assess whether fish communities responded differently to these habitat gradients above culverts compared to below. The habitat variables included in the principal components analysis were: basin area, depth, pool area per $50 \mathrm{~m}$ of stream, slope, CV of depth, distance to cover, large woody debris per $50 \mathrm{~m}$ of stream, $\mathrm{D}_{50}$, and average current velocity.

We performed stepwise multiple linear regressions with species richness and population densities of several species as response variables. We performed two tests each on each response variable separately for upstream sets of reaches $(n=47)$ and downstream sets of reaches $(n=$ 23), resulting in 16 separate regressions. For the first regression performed on each set of reaches, we used selected stream habitat measures as independent variables and results from these regressions were referred to as the "habitat models.” To reduce redundancy and error resulting from co-variation, we formed a correlation matrix on transformed habitat variables 
(Table 9) and threw out any variable that was highly correlated with $(r>0.40)$, and logically related to, a different variable. The variables selected for habitat model regressions included: basin area, slope, pool-riffle ratio, CV of depth, rapid visual habitat assessment, canopy cover, distance to mainstem, and $\mathrm{D}_{50}$. For the second regression performed on each set of reaches, we used principal components 1, 2, and 3 as the independent variables as well as three habitat variables that were not included within the principal components analysis: canopy cover, rapid visual habitat assessment, and distance to mainstem. The results from these regressions were referred to as "principal component models." For all tests we used a forward stepping procedure and set the probability for model entry at 0.15 . The alpha level for final model acceptance was set at 0.05 . Only community variables for which significant explanatory models were derived were included in further analyses.

Next, we wanted to test whether observed community variable values upstream of culverts were close to what we would expect given downstream (i.e. control) habitat models and habitat characteristics upstream. On those community variables for which significant models were produced, we applied the downstream reach model to upstream reaches to derive these expected values. For each variable, the strongest downstream model (either the habitat or the principal components model) was used for this derivation. We then plotted observed values against expected values among downstream reaches and performed a least squares linear regression. On the same graph we plotted upstream observed values against the derived upstream expected values (given the downstream model) and performed a second linear regression on this plot. The logic behind this test was that if there was no culvert effect on a particular fish community variable, then the upstream trendline should have a slope of close to one and be fairly similar to the downstream trendline and the distribution of points should be 
similar between the two plots. We performed this analysis only for species with a significant and meaningful downstream habitat model.

We then performed pairwise Wilcoxon signed ranks tests on those habitat variables that, based upon multiple regression analysis, were most influential to fish community variables found. Basin area was not included in this analysis when it was found to be important because it was measured at the culvert and would not be very different between upstream and downstream reaches. Distance to mainstem also was excluded for the same reason. These tests were only performed if a culvert effect was detected for a particular fish community variable. We defined a habitat variable as important if the removal of that variable would significantly reduce the explanatory power of a particular model $\left(\mathrm{r}^{2} \geq 0.05, \mathrm{p}<0.05\right)$. Testing was performed separately among group 1 culverts and group 2 culverts for each fish community variable affected by culverts.

Our null hypothesis was that any significant difference in a particular fish community variable found between above and below reaches could be attributed to habitat differences between above and below reaches and was not a culvert effect. Our alternative hypothesis was that any significant difference in a given fish community variable could be attributed to culvert presence alone. If any single important habitat variable was found to be significantly different between above and below reaches among group 1 culverts but not among group 2 culverts, then we would accept our null hypothesis. If any single important habitat variable was found to be significantly different between above and below reaches among group 1 culverts as well as among group 2 culverts, or if group 1 habitat was insignificant regardless of group 2, than we would reject the null hypothesis and accept our alternative hypothesis. One problem with this type of analysis is that by using multiple tests to answer a single question (e.g. tests on multiple 
habitat variables to answer whether habitat was different between upstream and downstream reaches among group 1 sites) the probability for type I error is compounded. To avoid this potential problem we used the bonferroni correction method for each separate set of tests. This method divides the significant alpha level by the number of tests performed to answer the question. The p-value for any single test must then be lower than this corrected alpha level to be considered a significant result.

Additionally, we hypothesized that culverts have less impact on species whose core ranges extend into small streams compared to species whose core ranges do not extend as far upstream. To explore this hypothesis we calculated the proportion of above-below sites where a given species was present upstream to the number of above-below sites where that species was present. Our theory was that if a species is usually present upstream of culverts in streams where it is found, then culvert effects on that species are probably negligible. Alternatively, a high proportion of sites at which a given species is present only in downstream reaches would indicate a greater culvert effect on that species. We then plotted these proportions against the core range upstream extent for each species. We used core ranges specific to fishes of the Cheat River basin that were published in Freund (2004). The core range upstream extent was defined as the basin area $\left(\mathrm{km}^{2}\right)$ at the $25^{\text {th }}$ percentile of the relative cumulative proportion of individuals of a given species (Freund 2004). This plot included all species that were present at no fewer than 3 abovebelow culvert sites, except brown trout (Salmo trutta). No core range was published for brown trout in Freund (2004). We then performed a least squares linear regression on this plot to find out if species-specific culvert effects are related to core range upstream extents.

Our final objective was to identify physical aspects of streams that might be related to culvert effects on fish communities. We performed separate linear regressions between habitat 
variables (independent variables) and pairwise differences in those fish community variables affected by culverts (independent variables). Mean habitat values [(value above + value below)/2] were used along with BA at the culvert and distance of the culvert to the mainstem (nearest point draining $15 \mathrm{~km}^{2}$ ) to identify whether culvert barrier effects on fishes within the basin were related to certain habitat types or streams of certain sizes or locations.

Finally, we plotted cumulative proportional species counts as well as cumulative proportional densities of the three most sampled species against both basin area and channel slope for all above-below sites. For both habitat variables two separate plots were performed: one for upstream reaches and one for downstream reaches. We then used Kolmogorov-Smirnov tests to identify whether the shapes of upstream curves differed significantly from the shapes of downstream curves. Such an effect would indicate that the culvert effect on that particular fish community variable was dependent upon the particular habitat variable being tested.

\section{Results}

Overall, fifteen species of fish representing five families were sampled within our study streams. The most represented family was Cyprinidae with seven species. The most common species were brook trout (Salvelinus fontinalis) (33 sites), mottled sculpin (Cottus bairdi) (24 sites), and blacknose dace (Rhinichthys atratulus) (20 sites) (Table 10). The maximum richness observed within one reach was eleven species at an above-only site. Several streams had no fish (17 reaches at 13 sites).

We found that all but one culvert had species richness differences of three or less. One site had a richness difference of seven, so we decided to remove this site from any further analysis. We believe this outlier occurred because of its proximity to the mainstem of Gandy Creek. The downstream reach at this culvert was essentially a backwater to Gandy Creek, so the 
high richness value (9 species) within the reach was a reflection of species diversity within the mainstem of Gandy Creek instead of the true diversity within this particular tributary.

Among above-below sites, the mean species richness for downstream reaches was 2.6 and the mean species richness for upstream reaches was 2.0. Pairwise testing revealed that species richness was significantly higher downstream of culverts than upstream $(p=0.014)$ (Table 11). Additionally, species richness accumulated with increasing basin area at a much faster rate in downstream reaches compared to upstream (Figure 22a). We also found that culverts crossing streams draining under $3.5 \mathrm{~km}^{2}$ had a higher likelihood of impacting species richness than culverts crossing larger streams (Figure 23a).

We focused our population analyses on the seven species of fish for which multiple regression analysis revealed significant explanatory models: mottled sculpin, brook trout, blacknose dace, creek chub (Semotilus atromaculatus), white sucker (catostomus commersoni), and rosyside dace (Clinostomus funduloides). Other species were too sparsely sampled to produce reliable results. Among above-below sites, mottled sculpin densities above culverts ranged from zero to 37.8 individuals per $100 \mathrm{~m}^{2}$ with a mean of 8.2 individuals per $100 \mathrm{~m}^{2}$. Below culverts, sculpin densities ranged from zero to 48.9 individuals per $100 \mathrm{~m}^{2}$ with a mean of 12.1 individuals per $100 \mathrm{~m}^{2}$. Brook trout densities above culverts ranged from zero to 44.4 individuals per $100 \mathrm{~m}^{2}$ with a mean of 6.2 individuals per $100 \mathrm{~m}^{2}$. Below culverts, brook trout densities ranged from zero to 20.0 individuals per $100 \mathrm{~m}^{2}$ with a mean of 5.7 individuals per 100 $\mathrm{m}^{2}$. Blacknose dace densities above culverts ranged from zero to 139.0 individuals per $100 \mathrm{~m}^{2}$ with a mean of 12.8 individuals per $100 \mathrm{~m}^{2}$. Below culverts, blacknose dace densities ranged from zero to 147.1 individuals per $100 \mathrm{~m}^{2}$ with a mean of 19.8 individuals per $100 \mathrm{~m}^{2}$. Creek chub densities above culverts ranged from zero to 62.2 individuals per $100 \mathrm{~m}^{2}$ with a mean of 2.4 
individuals per $100 \mathrm{~m}^{2}$. Below culverts, creek chub densities ranged from zero to 54.6 individuals per $100 \mathrm{~m}^{2}$ with a mean of 3.1 individuals per $100 \mathrm{~m}^{2}$. White sucker densities above culverts ranged from zero to 20.0 individuals per $100 \mathrm{~m}^{2}$ with a mean of 0.5 individuals per 100 $\mathrm{m}^{2}$. Below culverts, white sucker densities ranged from zero to 3.4 individuals per $100 \mathrm{~m}^{2}$ with a mean of 0.1 individuals per $100 \mathrm{~m}^{2}$. Rosyside dace densities above culverts ranged from zero to 14.1 individuals per $100 \mathrm{~m}^{2}$ with a mean of 0.5 individuals per $100 \mathrm{~m}^{2}$. Below culverts, rosyside dace densities ranged from zero to 7.1 individuals per $100 \mathrm{~m}^{2}$ with a mean of 0.4 individuals per $100 \mathrm{~m}^{2}$.

There was a consistent pattern among all species sampled, except for the two salmonid species (brook trout and brown trout), of lower mean densities above culverts than below (among above-below sites only). However, the only species present in significantly lower densities above culverts was blacknose dace $(\mathrm{p}=0.011)$ (Table 11). Additionally, blacknose dace densities accumulated at a much faster rate in downstream reaches compared to upstream reaches with increasing basin area (Figure 24a). Even though mottled sculpin densities were not found to be significantly higher downstream of culverts, they did accumulate at a much faster rate with increasing basin area in downstream reaches compared to upstream (Figure 25a), indicating a possible culvert effect on this species. Brook trout densities accumulated at about the same rate in downstream reaches compared to upstream with increasing basin area (Figure 26a). We opted not to produce similar curves for other species due to the limited number of sites where these species were present.

Principal components analysis revealed three significant habitat gradients that explained over $74 \%$ of variation among stream habitat variables. Principal component 1 (PC 1) was a stream/habitat size gradient that included basin area, depth, pool area per $50 \mathrm{~m}$ of stream, and 
average current velocity. Principal component 2 (PC 2) was a cover availability/habitat complexity gradient. PC 2 increased as distance to cover decreased and as large woody debris volume per $50 \mathrm{~m}$ of stream and $\mathrm{D}_{50}$ increased. Principal component 3 (PC 3) also was a habitat complexity gradient. The two variables influencing PC 3 were CV of depth (positive factor) and distance to cover (positive factor) (Table 12).

The downstream habitat model explained $62 \%$ of the variation in species richness among downstream reaches and was significant $(\mathrm{p}<0.001)$. The two factors included in this model were slope (negative factor) and basin area (positive factor) (Table 13). The most important habitat factors influencing species richness within the upstream habitat model were slope (negative factor), basin area (positive factor), and pool-riffle ratio (positive factor). Overall, the upstream habitat model explained $73 \%$ of the variation in species richness among upstream reaches and was significant $(\mathrm{p}<0.001)$ (Table 14). Slope was more important than basin area in determining species richness both upstream and downstream of culverts, however the importance of slope was much reduced below culverts compared to above and the importance of basin area increased below culverts (Tables 13 and 13).

The downstream principal components model explained $68 \%$ of the variation in species richness among downstream reaches and was significant $(\mathrm{p}<0.001)$. The factors influencing species richness within this model were PC 1 (positive factor), PC 3 (positive factor), and PC 2 (negative factor) (Table 15). The factors influencing species richness within the upstream principal component model were PC 1, PC 3, PC 2, and distance to mainstem. Species richness was positively correlated with both PC 1 and PC 3 and negatively correlated with PC 2 and distance to mainstem. The upstream principal component model explained $66 \%$ of the variation in species richness among upstream reaches and was significant $(\mathrm{p}<0.001)$ (Table 16). The 
importance of both PC 3 and PC 2 increased downstream compared to upstream (Tables 15 and 16).

The downstream habitat model explained $35 \%$ of the variation in mottled sculpin density among downstream reaches and was significant $(\mathrm{p}=0.011)$. The only significant explanatory variable in this model was slope (negative factor) (Table 13). The most important habitat factors influencing mottled sculpin density within the upstream habitat model were basin area, CV of depth, and rapid visual habitat score. Mottled sculpin densities upstream of culverts were positively correlated with basin area and rapid visual habitat assessment and negatively correlated with CV of depth. Overall, the upstream habitat model explained $43 \%$ of the variation in mottled sculpin density among upstream reaches and was significant $(\mathrm{p}<0.001)$ (Table 14).

The downstream principal components model explained $40 \%$ of the variation in sculpin density among downstream reaches and was significant $(\mathrm{p}=0.005)$. The factors influencing sculpin density within this model were PC 3 and PC 1, and both were positive factors (Table 15). The factors influencing mottled sculpin density within the upstream principal component model were PC 1 and canopy cover, and both were positive factors. Together these two factors explained $38 \%$ of the variation in mottled sculpin density among upstream reaches and resulted in a significant model $(\mathrm{p}<0.001)$ (Table 16).

The downstream habitat model explained $37 \%$ of the variation in brook trout density among downstream reaches and was significant $(\mathrm{p}=0.024)$. Median substrate size $\left(\mathrm{D}_{50}\right.$, negative factor) and rapid visual habitat assessment (positive factor) were the two most important factors within this model (Table 13). Habitat factors influencing brook trout density within the upstream habitat model were rapid visual habitat assessment and CV of depth. Rapid 
visual habitat assessment was a positive factor and CV of depth was a negative factor. Overall, the upstream habitat model explained $22 \%$ of the variation in brook trout density among upstream reaches and was significant $(\mathrm{p}=0.005)$ (Table 14).

No factors were pulled into a downstream principal component model for brook trout with the probability for model entry set at 0.15 (Table 15). The most influential factors on brook trout density within the upstream principal component model were rapid visual habitat assessment (positive factor) and PC 2 (positive factor). This model explained $24 \%$ of the variation in brook trout density among upstream reaches and was significant $(\mathrm{p}=0.007)$ (Table 16).

The downstream habitat model explained $46 \%$ of the variation in blacknose dace density among downstream reaches and was significant $(\mathrm{p}=0.006)$. Rapid visual habitat assessment (positive factor) and canopy cover (negative factor) were the two important factors within this model (Table 13). Influential habitat factors on blacknose dace density within the upstream habitat model included canopy cover, basin area, distance to mainstem, and rapid visual habitat assessment. Blacknose dace densities in upstream reaches responded negatively to canopy cover and rapid visual habitat assessment and positively to basin area and distance to mainstem. Overall, the upstream habitat model explained $57 \%$ of the variation in blacknose dace density among upstream reaches and was significant $(\mathrm{p}<0.001)$ (Table 14). Unlike the upstream habitat model, rapid visual habitat assessment was a stronger factor influencing blacknose dace density than canopy cover downstream of culverts. Additionally, the importance of rapid visual habitat assessment increased downstream compared to upstream. The importance of canopy cover was much reduced compared to the upstream model, but was still a negative factor (Tables 13 and $14)$. 
The downstream principal components model explained $49 \%$ of the variation in blacknose dace density among downstream reaches and was significant $(\mathrm{p}=0.004)$. The most influential factor in determining blacknose dace density within this model was canopy cover (positive factor) (Table 15). The most influential factors on blacknose dace density within the upstream principal component model were canopy cover (negative factor), PC 1 (positive factor), and rapid visual habitat assessment (negative factor). This model explained $54 \%$ of the variation in blacknose dace density among upstream reaches and was significant $(\mathrm{p}<0.001)$ (Table 16). Canopy cover decreased in importance downstream of culverts compared to the upstream model (Tables 15 and 16).

The downstream habitat model explained $71 \%$ of the variation in creek chub density among downstream reaches and was significant $(\mathrm{p}<0.001)$. The most important factors to creek chub density were canopy cover (negative factor) and rapid visual habitat assessment (positive factor) (Table 13). The two factors that influenced creek chub densities upstream of culverts were canopy cover (negative factor) and slope (negative factor). The upstream habitat model explained $51 \%$ of the variation in creek chub density among upstream reaches and was significant $(\mathrm{p}<0.001)$ (Table 14).

The downstream principal component model explained $62 \%$ of the variation in creek chub density among downstream reaches and was significant $(\mathrm{p}<0.001)$. The three factors included in this model were canopy cover (negative factor), PC3 (negative factor), and rapid visual habitat assessment (positive factor) (Table 15). The upstream principal components model explained $50 \%$ of the variation in creek chub density among upstream reaches and was significant $(\mathrm{p}<0.001)$. The only important factor in this model was canopy cover, a positive factor (Table 16). 
The downstream habitat model explained $28 \%$ of the variation in white sucker density among downstream reaches and was significant $(\mathrm{p}=0.031)$. The only important factor in this model was pool-riffle ratio, a positive factor (Table 13). The upstream habitat model explained $27 \%$ of the variation in white sucker density among upstream reaches and was significant $(\mathrm{p}=$ 0.003). The two important factors included within this model were slope and rapid visual habitat assessment, both negative factors (Table 14).

The downstream principal components model explained $35 \%$ of the variation in white sucker density among downstream reaches and was significant $(\mathrm{p}=0.011)$. The most important factor included in this model was PC3, a positive factor (Table 15). The upstream principal components model explained $30 \%$ of the variation in white sucker density among upstream reaches and was significant $(\mathrm{p}=0.002)$. Factors included in this model were PC3 (positive factor), PC2 (negative factor), and distance to mainstem (negative factor) (Table 16).

The downstream habitat model explained $44 \%$ of the variation in rosyside dace density among downstream reaches and was significant $(\mathrm{p}=0.002)$. The most important factor in this model was pool-riffle ratio, a positive factor (Table 13). The upstream habitat model explained $40 \%$ of the variation in rosyside dace density among upstream reaches and was significant ( $\mathrm{p}<$ 0.001). The two most important factors influencing rosyside dace density within this model were slope (negative factor) and pool-riffle ratio (positive factor) (Table 14). The importance of slope was dramatically reduced in downstream reaches compared to upstream reaches, while the importance of pool-riffle ratio increased (Tables 13 and 14).

The downstream principal component model explained $36 \%$ of the variation in rosyside dace density among downstream reaches and was significant $(p=0.009)$. The two factors included in this model were PC1 and PC3, both positive factors (Table 15). The upstream 
principal component model explained $47 \%$ of the variation in rosyside dace density among upstream reaches and was significant $(\mathrm{p}<0.001)$. The four important factors in this model were PC3 (positive factor), distance to mainstem (negative factor), PC2 (negative factor), and PC1 (positive factor) (Table 16). Additionally, the importance of PC1 was greatly reduced upstream of culverts compared to downstream (Tables 15 and 16).

Principal components models were the best models for explaining variation among downstream reaches in the following fish community variables: species richness, mottled sculpin density, blacknose dace density, and white sucker density. Habitat models were the best models for explaining variation among downstream reaches in the following variables: brook trout density, creek chub density, and rosyside dace density. The trendline explaining the relationship between expected and observed species richness downstream of culverts had a slope of 1.00, while the upstream trendline had a slope of 0.88 . Overall, $56 \%$ of upstream points expected to be greater than zero fell below the downstream trendline (Figure 27a).

The trendline explaining the relationship between expected and observed mottled sculpin density downstream of culverts had a slope of 1.01, while the upstream trendline had a slope of 0.33. Overall, $69 \%$ of upstream points expected to be greater than zero fell below the downstream trendline (Figure 27b). The trendline explaining the relationship between expected and observed brook trout density downstream of culverts had a slope of 1.00, while the upstream trendline had a slope of 0.52 . Overall, $55 \%$ of upstream points expected to be greater than zero fell below the downstream trendline (Figure 27c). The trendline explaining the relationship between expected and observed blacknose dace density downstream of culverts had a slope of 1.00, while the upstream trendline had a slope of 0.42 . Overall, $93 \%$ of upstream points expected to be greater than zero fell below the downstream trendline (Figure 27d). The trendline 
explaining the relationship between expected and observed creek chub density downstream of culverts had a slope of 0.99 , while the upstream trendline had a slope of 0.36 . Overall, $93 \%$ of upstream points expected to be greater than zero fell below the downstream trendline (Figure 27e). The trendline explaining the relationship between expected and observed white sucker density downstream of culverts had a slope of 1.15 , while the upstream trendline had a slope of 2.20. Overall, $90 \%$ of upstream points expected to be greater than zero fell below the downstream trendline (Figure 27f). The trendline explaining the relationship between expected and observed rosyside dace density downstream of culverts had a slope of 0.54 , while the upstream trendline had a slope of 0.65 . Overall, $83 \%$ of upstream points expected to be greater than zero fell below the downstream trendline (Figure 27g).

The fact that upstream trendlines were less than one for species richness as well as mottled sculpin, brook trout, blacknose dace, and creek chub densities indicated that observed values were consistently less than what we would expect given the downstream predictive model. Additionally, those species that had upstream trendlines of greater than one had a vast majority of points that occurred below the downstream trendline. These two results indicate consistent upstream culvert effects.

Because species richness and blacknose dace density were the only two fish community variables that differed significantly between upstream and downstream reaches, these were the only two variables that were included in post-hoc pairwise testing of habitat variables. Site groupings as they relate to these two variables can be observed in Figures 28 and 29. The variables deemed most important to determining species richness were slope, BA, PC 1, PC 2, and PC 3. Based upon pairwise testing of each of these variables, except BA, habitat was not significantly different between upstream and downstream reaches among group 1 sites, nor was 
it different among group 2 sites (Table 17). Because we tested four variables within this group of tests, our bonferroni-corrected alpha level for significance was 0.01 . Based upon these results, we rejected our null hypothesis that culverts do not impact species richness and accepted our alternative that reductions in species richness upstream of culverts could be explained by culvert presence alone. The habitat variables deemed most important to determining blacknose dace density were CC, BA, RVHA, and PC 1. Based upon pairwise testing of each of these variables, except BA, habitat was not significantly different between upstream and downstream reaches among group 1 sites, nor among group 2 sites (Table 18). Because we tested three variables within this group of tests, our bonferroni-corrected alpha level for significance was 0.02. Based upon these results, we rejected our null hypothesis that culverts do not impact blacknose dace density and accepted our alternative that reductions in blacknose dace densities upstream of culverts could be explained by culvert presence alone.

Among all above-below sites (sites sampled both upstream and downstream of the culvert), species richness differences (downstream-upstream) were found to be positively correlated ( $r=0.44, p=0.033)$ with the distance of the culvert to the nearest point draining 15 $\mathrm{km}^{2}$ (Table 19, Figure 30) and negatively correlated with CVACV $(r=-0.47, \mathrm{p}=0.025)$ (Table 19, Figure 31). Additionally, among above-below sites, blacknose dace density differences (downstream - upstream) appeared to be positively correlated with $\mathrm{D}_{50}(\mathrm{r}=0.49, \mathrm{p}=0.018)$ (Table 20, Figure 32). However, this correlation was primarily influenced by one site that happened to have both a very high median substrate size and a large difference in blacknose dace density. After removal of this outlier we found that blacknose dace densities were not correlated with median substrate size at all $(r=0.06)$ (Figure 33). 
All Kolmogrov-Smirnov tests between upstream reach and downstream reach curves of cumulative proportional species count, cumulative proportional blacknose dace densities, and cumulative proportional mottled sculpin densities turned out to be insignificant (Table 21). Regardless of the fact that these tests were insignificant, it still appears that species richness accumulates at a much faster rate downstream of culverts located in stream draining under 3.5 $\mathrm{km}^{2}$ (Figure 22). Additionally, even though Kolmogorov-Smirnov tests revealed no significant differences in cumulative mottled sculpin densities upstream compared to downstream, it appears that scuplin densities accumulate at a much faster rate downstream of culverts at smaller sites (Figure 25). No basin area or slope dependencies of the blacknose dace culvert effect were found (Figure 24). Finally, we found that the proportion of culvert sites where a given species was present upstream of the culvert to the number of above-below sites where that species was found was negatively correlated to the upstream extent of the core range $(r=-0.76, p=0.049)$ (Figure 34). This result indicates that culverts have a greater impact on species whose core ranges do not extend as far upstream.

\section{Discussion}

We found that fish communities in streams of the upper Cheat River basin have been negatively impacted by the presence of culverts. Specifically, we found that species richness was reduced upstream of culvert crossings and blacknose dace populations were significantly reduced upstream of culvert crossings. To further back up these findings, observed richness and blacknose dace density values were typically lower than expected upstream of culverts given downstream predictive models as indicated by upstream expected versus observed trendline slopes of much less than one. Additionally, all species except the two salmonid species sampled, 
brook trout and brown trout (Salmo trutta), had lower average densities upstream of culverts compared to downstream (Table 11).

We attribute these results to habitat isolation. When an impassable barrier is placed within a stream channel, upstream movements are blocked. For example, Warren and Pardew (1998) found that movement of fish was an order of magnitude lower through culverts than through natural reaches. The resulting isolation above a barrier may lead to local extirpation of populations above that barrier (Winston et al. 1991; Fausch and Young 1995; Morita and Yamamoto 2002) or create small habitat patches that may make populations more susceptible to reductions in genetic diversity (Fausch and Young 1995; Donaldson and Nisbet 1999; Hilderbrand and Kershner 2000). Immigration also is an important function that often supplements "sink" populations where death rates exceed birth rates. Isolation of these types of populations may lead to their local extirpation (Pulliam 1988).

Several studies have noted the extirpation of stream fish populations or a reduction in species richness above barriers. Morita and Yamamoto (2002) found that white-spotted charr (Salvelinus leucomaenis) populations were absent from 17 of 52 study sites located above dams where populations were predicted to occur. They found that local population extirpation was positively correlated with increasing isolation period and decreasing habitat size above the dam (Morita and Yamamoto 2002). Winston et al. (1991) noted that only 25 fish species were collected in the North Fork of the Red River, OK, above Altus dam compared to 33 in a tributary that enters below the dam and 34 in the North Fork below the dam. The speckled chub (Macrhybopsis aestivalis) and the chub shiner (Notropis potteri) were extirpated above the dam, but were fairly common in similar streams elsewhere. Additionally, they found that two of the most common species found in the southwest region of Oklahoma, the plains minnow 
(Hybognathus placitus) and the red river shiner (Notropis bairdi) were not collected above the dam in a 1989 survey, and were only collected in small numbers intermittently in long-term surveys. The researchers speculated that these two species have been repeatedly extirpated and reestablished as "bait-bucket" introductions (Winston et al. 1991).

It is possible that the culvert barrier effect on species richness was confounded with pairwise differences in channel slope between upstream and downstream sample reaches. Among sites where richness was reduced above the culvert (group 1 sites), slope was close to being significantly higher upstream. The p-value (0.02) for this test was just higher than the bonferroni-corrected alpha level (0.01) for this group of tests (Table 17). In fact, this probably was the case at a few culverts. But it is unlikely that this happened at all culverts where a richness effect was observed. The simplest interpretation of this result is that the culvert effect on species richness was slope-dependent and that slope influenced whether culverts were barriers. In fact, we found that culverts located in streams with slopes over $5 \%$ were much more likely to be fish passage barriers than culverts located in streams with slopes under $5 \%$ (see chapter 2). It also may be the case that this was a combined slope-culvert presence effect where culvert isolation had a greater impact on fish communities in streams with higher gradients above the culvert than below. High gradient reaches may be less likely to maintain local populations of certain species after stochastic events, and are not likely to recolonize afterwards if they are isolated from immigration. Evidence for this theory was observed in the multiple regression results. Slope was much more important in determining richness above the culvert $\left(r^{2}=0.58\right)$ than below $\left(r^{2}=0.40\right)$. We believe that this difference in importance was a function of reach isolation. If differences in slope were the only factor affecting species richness, and culvert 
presence was not a factor, then slope would have been equally as important to determining richness downstream of the culvert as it was upstream.

Blacknose dace, a species ubiquitous in this basin (Freund 2004), was probably limited by barriers due to its poor swimming abilities compared to other species. Nelson et al. (2003) reported critical swimming speeds for adult blacknose dace within the range of 26 and $69 \mathrm{~cm} / \mathrm{s}$ depending on which home-stream they were from, while small adult brook trout (110-116 mm standard length), for example, have been reported to have critical swimming speeds of 68 to 93 cm/s (Wolter and Arlinghaus 2003) and white sucker (170-370 mm in fork length) have critical swimming speeds from 169 to 259 cm/s (Jones et al. 1974). Our findings agree with Warren and Pardew (1998) who found that the numbers of species and movement within the family Cyprinidae, the family to which blacknose dace belongs, were reduced at culverts relative to natural reaches. These researchers also found that fish passage through short culverts $(<10 \mathrm{~m}$ in length), like culverts in our study, was substantially reduced at water velocities above $40 \mathrm{~cm} / \mathrm{s}$. This result suggesting that flows for small-stream, non-migratory, fishes need to be much lower than the maximum suggested crossing flows for migratory fishes (Warren and Pardew 1998).

It was of no surprise that blacknose dace and creek chub densities were negatively correlated with percent canopy cover. This was probably a result of increased productivity within reaches that receive more sunlight from reduced overhead canopies. Additionally, both species, when present in high numbers, may be indicative of both local and regional impairment (Freund 2004) and are typically classified as tolerant species in biomonitoring programs (e.g. McCormick et al. 2001). Low canopy cover within these streams was usually indicative of surrounding agricultural land-use (i.e. cow pasture) without a riparian buffer. Thus, low canopy 
cover in our study area was indicative of a source of local impairment that these populations positively respond to.

In general, species richness and populations densities of most species responded negatively to stream slope and positively to basin area or stream size (i.e. PC1). The exception to this pattern was brook trout. Brook trout densities typically responded negatively to slope which we would expect considering that brook trout are a small stream core species (Freund 2004).

It is probably case that other species were negatively impacted by culverts as well, but our tests were not powerful enough to detect the effect. As evidence, it was apparent that all non-game fish species, except creek chub, had consistently lower densities upstream of the culvert compared to below. In fact, three species (mottled sculpin, white sucker, and longnose dace) had upstream densities that were over $30 \%$ lower than downstream densities and two of these were over $50 \%$ different (Table 11). However, pairwise testing on these densities revealed no significant difference. Our simplest explanation is that these species were probably impacted by culverts where found, but the general lack of sites where they were sampled reduced the power of each pairwise test and we were not able to detect the true culvert effect. White sucker and longnose dace were found at five or fewer sites and sculpin were found at only 13 sites (Table 11). Additionally, mottled sculpin densities accumulated at a much higher rate with increasing basin area in downstream reaches compared to upstream (Figure 25). Further evidence that other species were impacted by culverts lies in the fact that a vast majority of upstream observed creek chub, white sucker, and rosyside dace density values fell below downstream expected-observed trendlines, indicating that culverts often caused density values to be much lower than expected given downstream habitat models. If we were to sample additional 
culvert sites where these species were present and increase our sample size for each test, we would probably detect an effect on several additional species.

It also was apparent that populations of brook trout were locally unimpacted by culvert presence. In fact average densities of this species were actually higher above culverts than below, but not significantly higher. However, it is likely that this species was impacted by culverts but this effect was not apparent through our sampling design. This species is a small stream core species (Freund 2004) and, in many cases, culverts were located within or downstream of core ranges (i.e. source populations), so upstream culvert effects are probably rare on brook trout. In fact, we found that species-specific upstream culvert effects are related to the upstream extent of a species core range (Figure 34). This is probably the case because all of our culverts were located in small streams and were further from the core range of species that have core ranges located in larger streams. Thus, if one of these large stream population core species was present in a stream we sampled, the culvert probably isolated a small fraction of the population periphery making that species more vulnerable to local extirpation above the culvert than a species with a larger portion of its core located upstream of the culvert.

In fact, brook trout probably are actually impacted by culverts, but at the watershed scale, through the additive effects of habitat isolation by many culverts. However, our culverts were probably located within or just downstream of these source populations making the detection of local effects on brook trout impossible. Our study was not designed to identify watershed-scale impacts. In fact, it would be difficult to design such a study in the central Appalachian region due to the lack of roadless watersheds for use as experimental controls.

Several results suggest that culvert effects on fish communities are basin area dependent and that culverts located within the smallest fish-bearing streams probably have a stronger effect 
than culverts crossing the larger streams (Figures 22a and 23a). For example, we observed no difference in species richness between upstream and downstream reaches at sites larger than 3.5 $\mathrm{km}^{2}$. Additionally, it appeared that relative species accumulation occurred at a faster rate downstream of culverts compared to upstream at sites under $3.5 \mathrm{~km}^{2}$ compared to sites over this size. We also found strong evidence that suggests that culvert effects on mottled sculpin densities were basin area-dependent. It appears that culverts located in streams draining between 1.0 and $2.0 \mathrm{~km}^{2}$ have the most impact on mottled sculpin (Figure 25b). Small streams probably have a greater effect on fish communities because they are located further from most species core ranges and isolate smaller population periphery fragments that are highly vulnerable to local extirpation.

We attribute the fact that we did not detect a more drastic culvert effect on upper Cheat River basin fish assemblages to several situational and biogeographical variables. First, although we suspect that additional species are significantly impacted by culverts and that, by increasing the power of our tests, we would probably detect a culvert effect these species, it is probably rare that we could find many barrier culverts that overlap the range of these species. We found that culverts on smaller streams with steeper slopes probably have more impact than other culverts but these additional species are large stream core species that occur in streams that are larger and lower in gradient. Second, the fact that we chose a watershed with a small species pool limited our chances of actually detecting an effect from the start. Other studies that have detected culvert effects have been conducted in much more speciose watersheds. For example, Warren and Pardew (1998) studied culvert effects on 21 fish species in small streams of the Ouichita Mountains compared to the 13 species found at sites where we sampled both downstream and upstream of the culvert in our study. Moreover, Warren and Pardew (1998) were working in 
warmwater streams which were larger and lower in gradient ( $0.8 \%$ mean gradient among study streams). In our study area, streams of this nature are typically bridged, not culverted. Finally, it is probably true that culvert effects in the Cheat River basin will become more apparent over time. As time goes on and more disturbance events such as debris flows or droughts occur, the likelihood that a disturbance will occur upstream of a barrier culvert will only increase. Such an event would cause the decimation of a stream reach isolated to recolonization. Therefore, as time goes on, fish assemblages in these isolated stream reaches become more vulnerable to extreme disturbances.

In addition to these findings, we found that pairwise richness differences between downstream and upstream sites were positively correlated $(r=0.44)$ with the distance of the culvert from the mainstem (i.e. source populations) and negatively correlated $(r=-0.47)$ with longitudinal variation in flow velocity within a given reach (i.e. flow complexity). The positive correlation of richness difference with distance to the mainstem seems counter-intuitive. However, it is probably a result of the fact that stream slope typically increases and basin area typically decreases moving away from the mainstem and culvert effects are associated with small steep streams in our study area (see chapter 2). The negative correlation with variation in flow velocity might be a result of the lack of resting habitats near the culvert in streams with less variable flow velocity. This lack of resting habitat approaching the culvert might result in a reduction in the probability of successful fish passage when the fish reaches the culvert.

Warren and Pardew (1998) found that stream fish movements were an order of magnitude lower through culverts than through natural reaches. Similarly, Thompson and Rahel (1998) found that culverts were effective barriers to brook trout. While our study was not designed to measure fish movement, our results are indicative of the expected impacts of reduced 
fish movement on fish communities upstream of culverts. Additionally, our result that blacknose dace, a member the the Cyprinidae family, support findings by Warren and Pardew (1998) who found that the numbers of species and movement within the family Cyprinidae were reduced at culverts relative to natural reaches.

\section{Conclusions and Implications}

We were able to draw four major conclusions from this research. First, species richness is negatively impacted by culverts. Second, culvert effects are related to basin area, stream slope, distance to the mainstem, and flow variability. Culverts on small streams with steep slopes where fish are present are more likely to have impacts on the fish community. Additionally, culvert effects on richness were negatively correlated with flow variability. Third, blacknose dace populations are significantly impacted by culverts. Other species, other than brook trout, appear to impacted as well, but probably were not sampled often enough to be sure. Finally, the relationship between species-specific culvert effects was positively correlated with the basin area at the upstream extent of a given species core range.

Our results underline the importance and vulnerability of headwater streams which comprise the majority of the total catchment area (70 - $80 \%$ ) of most watersheds (Sidle et al. 2000) and support an important component of biodiversity in watersheds (Gomi et al. 2002). Additionally, headwater streams are intimately linked to downstream ecosystems and are important to managing and protecting these ecosystems (Gomi et al. 2002). Our results provide further proof that environmental managers and road builders need to pay as much attention to headwater streams as they do larger streams during road building and mitigation efforts, because headwater streams are essential to healthy stream ecosystems and are vulnerable to culvertrelated impacts. 
Additionally, this study opens various research avenues. There is a need for studies addressing genetic variation within small-stream fish populations isolated above barriers. Additionally, there is a need for studies addressing the responses of isolated fish communities after stochastic events such as large floods and droughts. There also is a need for studies addressing the long-term impacts of various culvert designs in small, high gradient, headwater streams and a need to develop an economical road crossing design that has minimal impact on stream biota. Currently bridges and bottomless arch culverts are the most ecologically sound stream crossing option, but they also are the most expensive.

Our results also hold implications for future culvert design criteria and culvert replacement decisions. In the past, salmonid species have been the main focus of most fish passage concern because they are usually the most economically important species (e.g. Fitch 1995). These results suggest, perhaps, that we should shift more attention toward weaker swimming species and species whose core ranges are located in larger streams when dealing with passage concerns and setting fish passage standards. If passage standards are met for the weakest swimmers, or benthic organisms such as salamanders, then standards for all species should be met and the whole stream ecosystem should benefit. This would require a holistic, interdisciplinary approach to culvert design, such as that proposed in Sylte (2002) in which engineers, hydrologists, and ecologists all agree on mutually beneficial stream crossing designs.

This study shows that culvert isolation, in addition to many other anthropogenic impacts, does negatively impact fish communities within the Cheat River basin, West Virginia. However, we found that culverts in this basin have the greatest impact on small steep streams, making the amount of recoverable upstream habitat negligible in most cases. Moreover, culvert impacts are greatest on ubiquitous species that are in no critical danger within this basin (i.e. blacknose dace) 
and large stream core species that are not likely to be located in the most impacted streams.

Therefore, even though it is apparent that culverts negatively impact fish communities in this basin, remediation of these impacts is likely not as critical as the remediation of other problems such as acid precipation impacts and acid mine drainage impacts. However, if culvert restoration efforts are teamed with acid rain and acid mine remediation, or other restoration efforts, the potential exists to maximize the amount of stream habitat and connectivity restored to the basin.

\section{Literature Cited}

Angermeier, P.L., A.P. Wheeler, and A.E. Rosenberger. 2004. A conceptual framework for assessing impacts of roads on aquatic biota. Fisheries 29: 19-29.

Barbour, M.T., J. Gerritsen, B.D. Snyder, and J.B. Stribling. 1999. Rapid bioassessment protocols for use in streams and wadeable rivers: periphyton, benthic macroinvertebrates and fish, second edition. EPA 841-B-99-002. U.S. Environmental Protection Agency; Office of Water; Washington, D.C. 339 pp.

Bates, K., B. Barnard, B. Heiner, J.P. Klavas, and P.D. Powers. 2003. Design of road culverts for fish passage. Washington Department of Fish and Wildlife. 110 pp.

Beschta, R.L. 1978. Long-term patterns of sedimentation following construction and logging in the Oregon Coast Range. Water Resources Research 14: 1011-1016.

Bevenger, G.S., and R.M. King. 1995. A pebble count procedure for assessing watershed cumulative effects. Research Paper RM-RP-319. Fort Collins, CO: USDA Forest Service, Rocky Mountain Forest and Range Experiment Station. 17 pp.

Czech, B., P.R. Krausman, and P.K. Devers. 2000. Economic associations among species endangerment in the United States. Bioscience 50: 593-601.

Clapp, D.F., R.D. Clark, Jr., and J.S. Diana. 1990. Range, activity, and habitat of large freeranging brown trout in a Michigan stream. Transactions of the American Fisheries Society 119: 1022-1034.

Davies, P.E., and M. Nelson. 1993. The effect of steep slope logging on fine sediment infiltration into the beds of ephemeral and perrennial streams of the Dazler Range, Tasmania, Australia. Journal of Hydrology 150: 481-504.

Donalson, D. D. and R. M. Nisbet. 1999. Population dynamics and spatial scale: effects of system size on population persistence. Ecology 80:2492-2507. 
Fausch, K.D., and M.K. Young. 1995. Evolutionary significant units and movement of resident stream fishes: a cautionary tale. American Fisheries Society Symposium 17: 360-370.

Fitch, G.M. 1995. Nonanadromous fish passage in highway culverts. Virginia Transportation Research Council Report No. VTRC 96-R6. 18 pp.

Forman, R.T.T. 1995. Land mosaics: the ecology of landscapes and regions. Cambridge University Press, Cambridge, United Kingdom.

Forman, R.T.T. 2000. Estimate of the area affected ecologically by the road system in the united states. Conservation Biology 14: 31-35.

Freund, J.G. 2004. Local and regional impairment of fish assemblages in a mined Appalachian watershed. Doctoral Dissertation, West Virginia University. 164 pp.

Gomi, T., R.C. Sidle, and J.S. Richardson. 2002. Understanding processes and downstream linkages of headwater systems. Bioscience 52: 905-916.

Hartman, G.F., J.C. Scrivener, and M.J. Miles. 1996. Impacts of logging in Carnation Creek, a high energy coastal stream in British Columbia, and their implication for restoring fish habitat. Canadian Journal of Fisheries and Aquatic Sciences 53 (supplement 1): 237-251.

Harvey, B.C. 1991. Interactions among stream fishes: predator-induced habitat shifts and larval survival. Oecologia 87: 29-36.

Hilderbrand, R.H. and J. L. Kershner. 2000. Conserving inland cutthroat trout in small streams: how much stream is enough? North American Journal of FisheriesManagement 20:13520.

Hunt, R.L. 1974. Annual production by brook trout in Lawrence Creek during eleven successive years. Wisconsin Department of Natural Resources. Technical Bulletin 82: 28 pp.

Jackson, S.D., 2003. Ecological considerations in the design of river and stream crossings. Pages 20-29 in C.L. Irwin, P. Garrett, and K.P. McDermott, editors. Proceedings of the International Conference on Ecology and Transportation. Center for Transportation and the Environment, North Carolina State University, Raleigh, North Carolina.

Johnston, T.A. 1997. Downstream movements of young-of-the-year fishes in Catamaran Brook and the Little Southwest Miramichi River, New Brunswick. Journal of Fish Biology 51: 1047-1062.

Jones, D.R., J.W. Kiceniuk, and O.S. Bamford. 1974. Evaluation of the swimming performance of several fish species from the Mackenzie River. Journal of the Fisheries Research Board of Canada 31: 1641-1647. 
Kaeding, L.R. 1996. Summer use of coolwater tributaries of a geothermally heated stream by rainbow trout and brown trout, Oncorhynchus mykiss and Salmo trutta. American Midland Naturalist 135: 283-292.

Losche, C. K., and W. W. Beverage. 1967. Soil survey of Tucker County and part of Northern Randolph County, West Virginia. United States Department of Agriculture-Soil Conservation Service and Forest Service. 134 pp.

McCormick, F.H., R.M. Hughes, P.R. Kaufmann, D.V. Peck, J.L. Stoddard, and A.T. Herlinihy. 2001. Development of an index of biotic integrity for the Mid-Atlantic Highlands region. Transactions of the American Fisheries Society 130: 857-877.

Morita, K., and S. Yamamoto. 2002. Effects of habitat fragmentation by damming on the persistence of stream-dwelling charr populations. Conservation Biology 16: 1318-1323

Nelson, J.A., P.S. Gotwalt, and J.W. Snodgrass. 2003. Swimming performance of blacknose dace (Rhinichthys atratulus) mirrors home-stream current velocity. Canadian Journal of Fisheries and Aquatic Sciences 60: 301-308.

Petty, J.T., and D. Thorne. 2005. An ecologically based approach to identifying restoration priorities in an acid-impacted watershed. Restoration Ecology 13: 348-357.

Petty, J.T., and G.D. Grossman. 2004. Restricted movement by mottled sculpin (Pisces:Cottidae) in a Southern Appalachian stream. Freshwater Biology 49: 631-645.

Petty, J.T., and J. Barker. 2004. Water quality variability in tributaries of the Cheat River, a mined appalachian watershed. Proceedings of the American Society of Mining and Reclamation 25: 1484-1504.

Petty, J.T., J. Freund, P. Lamothe, and P. Mazik. 2001. Quantifying instream habitat in the upper Shavers Fork basin at multiple spatial scales. Proceedings of the Annual Conference of the Southeastern Association of Fish and Wildlife Agencies 55: 81-94.

Petty, J.T., P.A. Lamothe, and P.M. Mazik. 2005. Spatial and seasonal dynamics of brook trout populations in a central Appalachian watershed. Transactions of the American Fisheries Society 134: 572-587.

Pulliam, H. R. 1988. Sources, sinks, and population regulation. American Naturalist 132:652661.

Pyle, R. E., W. W. Beverage, T. Yoakum, D. P. Amick, W. F. Hatfield, and D. E. McKinney. 1982. Soil survey of Randolph County Area, main part, West Virginia. United States Department of Agriculture-Soil Conservation Service and Forest Service. pp. 167.

Reid, L.M., and T. Dunne. 1984. Sediment production from forest road surfaces. Water Resources Research 20: 1753-1761. 
Schlosser, I.J., and P.L. Angermeier. 1995. Spatial variation in demographic processes of lotic fishes: conceptual models, empirical evidence, and implications for conservation. American Fisheries Society Symposium 17:392-401.

Sidle, R.C., Y. Tsuboyama, S. Noguchi, I. Hosada, M. Fujieda, and T. Shimzu. 2000. Streamflow generation in steep headwaters: a linked hydro-geomorphic paradigm. Hydrological Processes 14: 369-385.

Simonson, T.D., J. Lyons, and P.D. Kanehl. 1994. Quantifying fish habitat in streams: transect spacing, sample size, and a proposed framework. North American Journal of Fisheries Management 14: 607-615.

Sweka, J.A., and K.J. Hartman. 2001. Influence of turbidity on brook trout reactive distance and foraging success. Transactions of the American Fisheries Society 130: 138-146.

Sylte, T.L. 2002. Providing for stream function and aquatic organism passage: an interdisciplinary design. Stream Notes, January 2002. 4 pp.

Thompson, P.D, and F.J. Rahel. 1998. Evaluation of artificial barriers in small rocky mountain streams for preventing the upstream movement of brook trout. North American Journal of Fisheries Management 18: 206-210.

Trombulak, S.C., and C.A. Frissell. 2000. Review of ecological effects of roads on terrestrial and aquatic communities. Conservation Biology 14: 18-30.

US Department of Transportation. 2003. Highway statistics 2003. U.S. Department of Transportations, Office of Highway Information Management, Washington, D.C.

Ward, R. 2005. The effects of roads and culverts on stream and stream-side salamander communities in Eastern West Virginia. Master’s Thesis, West Virginia University. 181 pp.

Warren, Jr., M.L., and M.G. Pardew. 1998. Road crossings as barriers to small stream fish movement. Transactions of the American Fisheries Society 127: 637-644.

Wellman, J.C., D.L. Combs, and S.B. Cook. 2000. Long-term impacts of bridge and culvert construction or replacement on fish communities and sediment characteristics of streams. Journal of Freshwater Ecology 15: 317-237.

Wolter, C., and R. Arlinghaus. 2003. Navigation impacts on freshwater fish assemblages: the ecological relevance of swimming performance. Reviews in Fish Biology and Fisheries 13: 63-89.

White, J.A. 2004. Geomorphic analysis of stream crossings in a portion of the upper Cheat River basin. Master's Thesis, West Virginia University. 71 pp. 
Wilcoxon, F. 1945. Individual comparisons by ranking methods. Biometrics Bulletin 1: 80-83.

Winston, R.W., C.M. Taylor, and J. Pigg. 1991. Upstream extirpation of four minnow species due to damming of a prairie stream. Transactions of the American Fisheries Society 120: 98-105.

Wood, P.J., and P.D. Armitage. 1997. Biological effects of fine sediment in the lotic environment. Environmental Management 21: 203-217.

WV DEP. 1996. An ecological assessment of the Cheat River watershed. WV DEP Office of Water Resources Report no. 0502004 - 1996. 279 pp. 


\section{$\underline{\text { Tables }}$}

Table 5: Physical characteristics of the three study sections within the upper Cheat River basin study area during summer 2004 fish assemblage sampling including boundary area $\left(\mathrm{km}^{2}\right)$, minimum elevation (m), maximum elevation (m), area of forested land-cover $\left(\mathrm{km}^{2}\right)$, and the top three surficial geological units ordered by surface area $\left(\mathrm{km}^{2}\right)$.

\begin{tabular}{lccccl}
\hline section & $\begin{array}{c}\text { min. } \\
\left(\mathrm{km}^{2}\right)\end{array}$ & $\begin{array}{c}\text { max. } \\
\text { elev. } \\
(\mathrm{m})\end{array}$ & $\begin{array}{c}\text { elev. } \\
(\mathrm{m})\end{array}$ & $\begin{array}{c}\text { forested } \\
\text { area } \\
\left(\mathrm{km}^{2}\right)\end{array}$ & $\begin{array}{c}\text { surficial geology: } \\
\text { area }\left(\mathrm{km}^{2}\right)\end{array}$ \\
\hline $\begin{array}{l}\text { upper } \\
\text { Dry Fork }\end{array}$ & 143.6 & 806 & 1,416 & 113.9 & $\begin{array}{l}\text { Hampshire: } 58.1 \\
\text { Mauch Chunk: } 43.1 \\
\text { Chemung: } 12.8\end{array}$ \\
$\begin{array}{l}\text { lower } \\
\text { Dry Fork }\end{array}$ & 311.2 & 494 & 1,496 & 263.9 & $\begin{array}{l}\text { Mauch Chunk: } 88.1 \\
\text { Pottsville: } 86.9\end{array}$ \\
& & & & & Hampshire: 55.1 \\
$\begin{array}{l}\text { Glady } \\
\text { Fork }\end{array}$ & 164.4 & 595 & 1,198 & 149.0 & $\begin{array}{l}\text { Hampshire: } 72.3 \\
\text { Chemung: } 47.3\end{array}$ \\
\hline
\end{tabular}

Table 6: First pass capture probabilities, based upon triple pass collection techniques, on streams of the Cheat River basin draining under $8 \mathrm{~km}^{2}$ for the fish species of main focus within this study.

\begin{tabular}{llc}
\hline species & $n$ & mean capture probability \\
\hline Catostomus commersoni & 3 & 0.92 \\
Clinsostomus funduloides & 1 & 0.87 \\
Cottus bairdi & 5 & 0.53 \\
Rhinichthys atratulus & 2 & 0.80 \\
Salvelinus fontinalis & 31 & 0.71 \\
Semotilus atromaculatus & 5 & 0.87 \\
\hline
\end{tabular}


Table 7: Results from pairwise two-tailed Wilcoxon signed ranks tests on water quality variables between upstream (US) and downstream (DS) culvert reaches for all above-below sites ( $\mathrm{n}=24)$. Water quality was no different upstream of culverts than downstream.

\begin{tabular}{|c|c|c|c|c|c|c|}
\hline \multirow[b]{2}{*}{ Variable } & \multicolumn{2}{|c|}{ mean(standard error) } & \multirow[b]{2}{*}{$\begin{array}{c}\% \\
\text { difference }\end{array}$} & \multirow[b]{2}{*}{$\begin{array}{c}W \\
\text { statistic }\end{array}$} & \multirow[b]{2}{*}{$d f$} & \multirow[b]{2}{*}{$p$-value } \\
\hline & upstream & downstream & & & & \\
\hline alkalinity (mg/L) & $46.7(8.8)$ & $47.6(8.6)$ & -1.9 & 50.5 & 15 & 0.639 \\
\hline calcium hardness (mg/L) & $3.3(0.5)$ & $3.2(0.5)$ & 3.0 & 40.0 & 13 & 0.735 \\
\hline $\mathrm{pH}$ & $7.18(0.12)$ & $7.24(0.12)$ & -0.8 & 129.0 & 24 & 0.565 \\
\hline specific conductivity $\left(\mu \mathrm{s} / \mathrm{cm}^{3}\right)$ & $117.1(17.7)$ & $115.4(17.7)$ & 1.5 & 108.5 & 22 & 0.588 \\
\hline total hardness (mg/L) & $4.4(0.5)$ & $4.3(0.5)$ & 2.3 & 33.5 & 12 & 0.733 \\
\hline
\end{tabular}


Table 8: A list of habitat variables used in multiple regression analysis of fish community data and transformations used on each respective dataset.

\begin{tabular}{|c|c|}
\hline Variable (X) & Transformation \\
\hline average current velocity & none \\
\hline basin area & $\log (x+1)$ \\
\hline canopy cover & $\arcsin (\sqrt{ } X)$ \\
\hline CV of average current velocity & none \\
\hline CV of depth & none \\
\hline depth & $\ln (x+1)$ \\
\hline $\mathrm{D}_{50}$ & $\log (x+1)$ \\
\hline distance to cover & $\ln (x+1)$ \\
\hline distance to mainstem & $\ln (x+1)$ \\
\hline large woody debris volume per $50 \mathrm{~m}$ of stream & $\log (x+1)$ \\
\hline pool area per $50 \mathrm{~m}$ of stream & $\ln (x+1)$ \\
\hline pool-riffle-ratio & $\ln (x+1)$ \\
\hline rapid visual habitat assessment & none \\
\hline percent silt/sand & $\arcsin (\sqrt{ } X)$ \\
\hline slope & $\arcsin (\sqrt{ } \mathrm{X})$ \\
\hline
\end{tabular}


Table 9: Correlation matrix of transformed habitat variables. Bolded variables were included as independent variables in stepwise multiple linear regressions. BA = basin area; DMS = distance to the mainstem; $\mathrm{CC}=$ canopy cover; slope $=$ stream gradient; $\mathrm{PA} / 50 \mathrm{~m}$ = pool area per $50 \mathrm{~m}$ of stream; $\mathrm{PRR}=$ pool-riffle ratio; $\mathrm{D}=$ depth; CVD = coefficient of variation of depth; ACV = average current velocity; CVACV = coefficient of variation of average current velocity; RVHA = rapid visual habitat assessment; D-cov = distance to fish cover; \% silt/sand = percent of substrate classified as silt or sand; LWD-vol/50m = large woody debris volume per $50 \mathrm{~m}$ of stream; $\mathrm{D}_{50}=$ median substrate size.

\begin{tabular}{|c|c|c|c|c|c|c|c|c|c|c|c|c|c|c|c|}
\hline & BA & DMS & $\mathrm{CC}$ & slope & $\mathrm{PA} / 50 \mathrm{~m}$ & PRR & $\mathrm{D}$ & CVD & ACV & CVACV & RVHA & D-cov & $\begin{array}{c}\% \\
\text { silt/sand }\end{array}$ & $\begin{array}{c}\text { LWD- } \\
\mathrm{vol} / 50 \mathrm{~m}\end{array}$ & D50 \\
\hline BA & 1.00 & -0.11 & -0.12 & -0.33 & 0.67 & 0.38 & 0.79 & -0.08 & 0.51 & -0.12 & 0.36 & -0.08 & -0.05 & 0.05 & 0.13 \\
\hline DMS & -0.11 & 1.00 & -0.08 & -0.11 & -0.01 & -0.16 & -0.16 & 0.05 & 0.06 & -0.28 & 0.04 & 0.31 & 0.24 & -0.04 & -0.15 \\
\hline CC & -0.12 & -0.08 & 1.00 & 0.20 & -0.03 & -0.16 & -0.11 & -0.04 & -0.09 & -0.03 & 0.38 & -0.36 & -0.08 & 0.46 & 0.01 \\
\hline slope & -0.33 & -0.11 & 0.20 & 1.00 & -0.44 & -0.23 & -0.47 & 0.03 & -0.29 & 0.38 & -0.18 & -0.27 & -0.24 & 0.31 & 0.30 \\
\hline $\mathrm{PA} / 50 \mathrm{~m}$ & 0.67 & -0.01 & -0.03 & -0.44 & 1.00 & 0.51 & 0.75 & 0.22 & 0.36 & 0.03 & 0.51 & -0.28 & -0.05 & 0.18 & 0.23 \\
\hline PRR & 0.38 & -0.16 & -0.16 & -0.23 & 0.51 & 1.00 & 0.43 & 0.36 & -0.20 & 0.41 & 0.04 & -0.03 & -0.08 & 0.18 & 0.12 \\
\hline$D$ & 0.79 & -0.16 & -0.11 & -0.47 & 0.75 & 0.43 & 1.00 & -0.12 & 0.68 & -0.26 & 0.49 & -0.22 & 0.00 & -0.03 & 0.02 \\
\hline CVD & -0.08 & 0.05 & -0.04 & 0.03 & 0.22 & 0.36 & -0.12 & 1.00 & -0.40 & 0.56 & -0.13 & 0.07 & -0.06 & 0.29 & 0.21 \\
\hline ACV & 0.51 & 0.06 & -0.09 & -0.29 & 0.36 & -0.20 & 0.68 & -0.40 & 1.00 & -0.60 & 0.47 & -0.18 & 0.10 & -0.18 & 0.01 \\
\hline CVACV & -0.12 & -0.28 & -0.03 & 0.38 & 0.03 & 0.41 & -0.26 & 0.56 & -0.60 & 1.00 & -0.24 & -0.02 & -0.11 & 0.34 & 0.30 \\
\hline RVHA & 0.36 & 0.04 & 0.38 & -0.18 & 0.51 & 0.04 & 0.49 & -0.13 & 0.47 & -0.24 & 1.00 & -0.49 & -0.08 & 0.20 & 0.15 \\
\hline D-Cov & -0.08 & 0.31 & -0.36 & -0.27 & -0.28 & -0.03 & -0.22 & 0.07 & -0.18 & -0.02 & -0.49 & 1.00 & 0.43 & -0.30 & -0.48 \\
\hline $\begin{array}{l}\% \\
\text { silt/sand }\end{array}$ & -0.05 & 0.24 & -0.08 & -0.24 & -0.05 & -0.08 & 0.00 & -0.06 & 0.10 & -0.11 & -0.08 & 0.43 & 1.00 & -0.21 & -0.73 \\
\hline $\begin{array}{l}\text { LWD- } \\
\mathrm{vol} / 50 \mathrm{~m}\end{array}$ & 0.05 & -0.04 & 0.46 & 0.31 & 0.18 & 0.18 & -0.03 & 0.29 & -0.18 & 0.34 & 0.20 & -0.30 & -0.21 & 1.00 & 0.25 \\
\hline D50 & 0.13 & -0.15 & 0.01 & 0.30 & 0.23 & 0.12 & 0.02 & 0.21 & 0.01 & 0.30 & 0.15 & -0.48 & -0.73 & 0.25 & 1.00 \\
\hline
\end{tabular}


Table 10: List of fish families (phylogenetic order) and species (alphabetical order) sampled at all sites (above-below as well as aboveonly culvert sites; $n=47$ ) including the number of culvert sites where each species was found and the number of below-culvert (downstream) and above-culvert (upstream) stream reaches where present.

\begin{tabular}{|c|c|c|c|c|}
\hline family & Species & $\begin{array}{c}\text { \# sites } \\
\text { where } \\
\text { present (47 } \\
\text { available) } \\
\end{array}$ & $\begin{array}{c}\text { \# downstream } \\
\text { reaches where } \\
\text { present (24 } \\
\text { available) }\end{array}$ & $\begin{array}{l}\text { \# upstream } \\
\text { reaches where } \\
\text { present (47 } \\
\text { available) }\end{array}$ \\
\hline \multirow[t]{7}{*}{ Cyprinidae } & Clinostomus funuloides (rosyside dace) & 8 & $5(21 \%)$ & $6(13 \%)$ \\
\hline & Nocomis micropogon (river chub) & 1 & 0 & $1(2 \%)$ \\
\hline & Notropis spp. (shiners) & 3 & $1(4 \%)$ & $3(6 \%)$ \\
\hline & Pimepheles notatus (bluntnose minnow) & 3 & $2(8 \%)$ & $2(4 \%)$ \\
\hline & Rhinichthys atratulus (blacknose dace) & 20 & $13(54 \%)$ & $15(32 \%)$ \\
\hline & Rhinichthys cataractae (longnose dace) & 7 & $5(21 \%)$ & $5(11 \%)$ \\
\hline & Semotilus atromaculatus (creek chub) & 11 & $7(29 \%)$ & $8(17 \%)$ \\
\hline \multirow[t]{2}{*}{ Catostomidae } & Catostomus commersoni (white sucker) & 6 & $4(17 \%)$ & $4(9 \%)$ \\
\hline & Hypentelium nigricans (northern hog sucker) & 2 & $1(4 \%)$ & $1(2 \%)$ \\
\hline \multirow[t]{2}{*}{ Salmonidae } & Salmo trutta (brown trout) & 6 & $2(8 \%)$ & $4(9 \%)$ \\
\hline & Salvelinus fontinalis (brook trout) & 33 & $14(58 \%)$ & $31(66 \%)$ \\
\hline Cottidae & Cottus bairdi (mottled sculpin) & 24 & $14(58 \%)$ & $21(45 \%)$ \\
\hline \multirow[t]{4}{*}{ Centrarchidae } & Ambloplites rupestris (rock bass) & 1 & 0 & $1(2 \%)$ \\
\hline & Lepomis cyanellus (green sunfish) & 1 & $1(4 \%)$ & 0 \\
\hline & Lepomis macrochirus (bluegill sunfish) & 1 & $1(4 \%)$ & 0 \\
\hline & Micropterus spp. (black bass) - juvenile & 1 & 0 & $1(2 \%)$ \\
\hline
\end{tabular}


Table 11: Results from pairwise two-tailed Wilcoxon signed ranks tests on fish species richness and species densities (\# individuals $/ 100 \mathrm{~m}^{2}$ ) between upstream (US) and downstream (DS) culvert reaches for all above-below sites except an outlier ( $\mathrm{n}=23$ ).

\begin{tabular}{|c|c|c|c|c|c|c|c|c|}
\hline \multirow[b]{2}{*}{ Variable } & \multicolumn{2}{|c|}{$\begin{array}{l}\text { \# sites with } \\
\text { fish present }\end{array}$} & \multicolumn{2}{|c|}{ mean(standard error) } & \multirow[b]{2}{*}{ \% difference } & \multirow[b]{2}{*}{ W statistic } & \multirow[b]{2}{*}{$d f$} & \multirow[b]{2}{*}{$p$-value } \\
\hline & US & $D S$ & upstream & downstream & & & & \\
\hline species richness & 17 & 19 & $2.0(0.5)$ & $2.6(0.5)$ & -22.0 & 3.5 & 10 & 0.014 \\
\hline Catostomus commersoni & 2 & 3 & $0.03(0.02)$ & $0.06(0.05)$ & -54.6 & 1.0 & 3 & 0.500 \\
\hline Cottus bairdi & 10 & 13 & $8.18(2.51)$ & $12.10(3.53)$ & -32.4 & 21.0 & 13 & 0.094 \\
\hline Clinostomus funduloides & 2 & 3 & $0.31(0.28)$ & $0.38(0.31)$ & -18.7 & 1.0 & 3 & 0.500 \\
\hline Rhinichtys atratulus & 9 & 12 & $12.80(7.32)$ & $19.76(8.13)$ & -35.2 & 10.0 & 13 & 0.011 \\
\hline Rhinichtys cataractae & 3 & 5 & $0.16(0.12)$ & $0.43(0.27)$ & -62.9 & 4.0 & 5 & 0.438 \\
\hline Semotilus atromaculatus & 4 & 6 & $3.10(2.70)$ & $3.08(2.37)$ & 0.5 & 8.0 & 6 & 0.688 \\
\hline Salvelinus fontinalis & 12 & 13 & $6.22(2.32)$ & $5.71(1.45)$ & 8.9 & 50.0 & 14 & 0.903 \\
\hline
\end{tabular}


Table 12: Results from principal components analysis of in-stream habitat variables. All stream reaches (above and below reaches) were included in this analysis $(\mathrm{n}=71)$

\begin{tabular}{|c|c|c|c|}
\hline Variable & Principal Component 1 & Principal Component 2 & Principal Component 3 \\
\hline eigenvalue & 3.24 & 2.09 & 1.35 \\
\hline percent & 35.98 & 23.17 & 15.05 \\
\hline average current velocity & 0.41 & $\bullet$ & $\bullet$ \\
\hline basin area & 0.47 & $\bullet$ & $\bullet$ \\
\hline CV of depth & $\bullet$ & $\bullet$ & 0.67 \\
\hline depth & 0.53 & $\bullet$ & $\bullet$ \\
\hline $\mathrm{D}_{50}$ & $\bullet$ & 0.52 & $\bullet$ \\
\hline distance to cover & $\bullet$ & -0.47 & 0.40 \\
\hline $\begin{array}{l}\text { large woody debris volume } \\
\text { per } 50 \mathrm{~m} \text { of stream }\end{array}$ & $\bullet$ & 0.49 & $\bullet$ \\
\hline $\begin{array}{l}\text { pool area per } 50 \mathrm{~m} \text { of } \\
\text { stream }\end{array}$ & 0.46 & • & $\bullet$ \\
\hline slope & $\bullet$ & $\bullet$ & • \\
\hline
\end{tabular}


Table 13: Results from step-wise multiple linear regression analysis between selected habitat variables and fish community variables on stream reaches located downstream of culverts $(\mathrm{n}=$ 24).

\begin{tabular}{|c|c|c|c|c|c|c|}
\hline$y$-response & habitat variable & $f$-value & $d f$ & $r^{2}$ & direction & $p$-value \\
\hline \multirow[t]{3}{*}{ species richness } & slope & 17.85 & 23 & 0.40 & - & $<0.001$ \\
\hline & basin area & 11.85 & 23 & 0.22 & + & 0.002 \\
\hline & model & 16.96 & 23 & 0.62 & & $<0.001$ \\
\hline \multirow[t]{3}{*}{ Cottus bairdii } & slope & 8.84 & 23 & 0.27 & - & 0.007 \\
\hline & pool-riffle ratio & 2.58 & 23 & 0.08 & + & 0.123 \\
\hline & model & 5.69 & 23 & 0.35 & & 0.011 \\
\hline \multirow[t]{4}{*}{ Salvelinus fontinalis } & $\mathrm{D}_{50}$ & 7.78 & 23 & 0.13 & - & 0.011 \\
\hline & basin area & 4.00 & 23 & 0.13 & - & 0.059 \\
\hline & $\begin{array}{l}\text { rapid visual habitat } \\
\text { assessment }\end{array}$ & 6.68 & 23 & 0.11 & + & 0.018 \\
\hline & model & 3.91 & 23 & 0.37 & & 0.024 \\
\hline \multirow[t]{4}{*}{ Rhinichthys atratulus } & $\begin{array}{l}\text { rapid visual habitat } \\
\text { assessment }\end{array}$ & 10.02 & 23 & 0.21 & + & 0.005 \\
\hline & canopy cover & 15.81 & 23 & 0.18 & - & 0.001 \\
\hline & slope & 2.55 & 23 & 0.07 & + & 0.126 \\
\hline & model & 5.63 & 23 & 0.46 & & 0.006 \\
\hline \multirow[t]{3}{*}{ Clinostomus funduloides } & pool-riffle ratio & 12.90 & 23 & 0.34 & + & 0.002 \\
\hline & slope & 3.63 & 23 & 0.10 & - & 0.071 \\
\hline & model & 8.24 & 23 & 0.44 & & 0.002 \\
\hline
\end{tabular}




\section{$\underline{\text { Table } 13 \text { continued }}$}

\begin{tabular}{|c|c|c|c|c|c|c|}
\hline$y$-response & habitat variable & $f$-value & $d f$ & $r^{2}$ & direction & $p$-value \\
\hline \multirow[t]{6}{*}{ Semotilus atromaculatus } & canopy cover & 44.40 & 23 & 0.31 & - & $<0.001$ \\
\hline & $\begin{array}{l}\text { rapid visual habitat } \\
\text { assessment }\end{array}$ & 22.54 & 23 & 0.21 & + & $<0.001$ \\
\hline & basin area & 2.98 & 23 & 0.11 & - & 0.101 \\
\hline & slope & 3.73 & 23 & 0.05 & + & 0.070 \\
\hline & pool-riffle ratio & 2.62 & 23 & 0.04 & - & 0.123 \\
\hline & model & 9.01 & 23 & 0.71 & & $<0.001$ \\
\hline \multirow[t]{3}{*}{ Catostomus commersoni } & pool-riffle ratio & 4.87 & 23 & 0.17 & + & 0.039 \\
\hline & slope & 3.43 & 23 & 0.12 & - & 0.078 \\
\hline & model & 4.13 & 23 & 0.28 & & 0.031 \\
\hline
\end{tabular}


Table 14: Results from step-wise multiple linear regression analysis between selected habitat variables and fish community variables on stream reaches located upstream of culverts $(\mathrm{n}=47)$.

\begin{tabular}{|c|c|c|c|c|c|c|}
\hline$y$-response & habitat variable & f-value & $d f$ & $r^{2}$ & direction & $\begin{array}{c}p- \\
\text { value }\end{array}$ \\
\hline \multirow[t]{5}{*}{ species richness } & slope & 27.03 & 46 & 0.58 & - & $<0.001$ \\
\hline & basin area & 12.67 & 46 & 0.10 & + & 0.001 \\
\hline & pool-riffle ratio & 6.55 & 46 & 0.03 & + & 0.014 \\
\hline & CV of depth & 2.92 & 46 & 0.02 & - & 0.095 \\
\hline & model & 27.75 & 46 & 0.73 & & $<0.001$ \\
\hline \multirow[t]{5}{*}{ Cottus bairdii } & basin area & 5.44 & 46 & 0.20 & + & 0.025 \\
\hline & CV of depth & 9.27 & 46 & 0.10 & - & 0.004 \\
\hline & $\begin{array}{l}\text { rapid visual habitat } \\
\text { assessment }\end{array}$ & 6.11 & 46 & 0.09 & + & 0.018 \\
\hline & pool-riffle ratio & 3.42 & 46 & 0.05 & + & 0.072 \\
\hline & model & 7.93 & 46 & 0.43 & & $<0.001$ \\
\hline \multirow[t]{3}{*}{ Salvelinus fontinalis } & $\begin{array}{l}\text { rapid visual habitat } \\
\text { assessment }\end{array}$ & 7.32 & 46 & 0.14 & + & 0.010 \\
\hline & CV of depth & 4.26 & 46 & 0.08 & - & 0.045 \\
\hline & model & 6.08 & 46 & 0.22 & & 0.005 \\
\hline \multirow[t]{6}{*}{ Rhinichthys atratulus } & canopy cover & 21.31 & 46 & 0.41 & - & $<0.001$ \\
\hline & basin area & 8.2 & 46 & 0.06 & + & 0.007 \\
\hline & distance to the mainstem & 4.65 & 46 & 0.04 & + & 0.037 \\
\hline & $\begin{array}{l}\text { rapid visual habitat } \\
\text { assessment }\end{array}$ & 7.28 & 46 & 0.03 & - & 0.010 \\
\hline & CV of depth & 3.07 & 46 & 0.03 & - & 0.087 \\
\hline & model & 10.97 & 46 & 0.57 & & $<0.001$ \\
\hline
\end{tabular}


$\underline{\text { Table } 14 \text { continued }}$

\begin{tabular}{lllllll}
\hline y-response & habitat variable & $f$-value & $d f$ & $r^{2}$ & direction of effect & $p$-value \\
\hline Clinostomus funduloides & slope & 12.24 & 46 & 0.23 & - & 0.001 \\
& pool-riffle ratio & 4.95 & 46 & 0.07 & + & 0.031 \\
& RVHA & 3.72 & 46 & 0.05 & - & 0.060 \\
& model & 9.37 & 46 & 0.40 & $<.001$ \\
Semotilus atromaculatus & CC & 32.77 & 46 & 0.46 & - & $<0.001$ \\
& slope & 4.24 & 46 & 0.05 & - & 0.045 \\
& model & 22.93 & 46 & 0.51 & & $<0.001$ \\
& slope & 11.41 & 46 & 0.13 & - & 0.002 \\
& RVHA & 5.16 & 46 & 0.08 & - & 0.028 \\
& DMS & 3.34 & 46 & 0.06 & - & 0.075 \\
& model & 5.33 & 46 & 0.27 & & 0.003 \\
\hline
\end{tabular}


Table 15: Results from step-wise multiple linear regression analysis between three significant habitat principal components as well as three habitat variables not included in the principal components analysis and fish community variables on stream reaches downstream of culverts (n =24). Principal component 1 (PC 1) is a positive habitat size component and both principal component 2 (PC 2) and principal component 3 (PC 3) are positive habitat complexity gradients.

\begin{tabular}{|c|c|c|c|c|c|c|}
\hline$y$-response & habitat variable & $f$-value & $d f$ & $r^{2}$ & direction & $p$-value \\
\hline \multirow[t]{4}{*}{ species richness } & PC 1 & 32.67 & 23 & 0.40 & + & $<0.001$ \\
\hline & PC 3 & 11.30 & 23 & 0.18 & + & 0.003 \\
\hline & PC 2 & 6.55 & 23 & 0.10 & - & 0.019 \\
\hline & model & 14.19 & 23 & 0.68 & & $<0.001$ \\
\hline \multirow[t]{3}{*}{ Cottus bairdii } & PC 3 & 8.09 & 23 & 0.23 & + & 0.010 \\
\hline & PC 1 & 9.03 & 23 & 0.17 & + & 0.007 \\
\hline & model & 6.98 & 23 & 0.40 & & 0.005 \\
\hline Salvelinus fontinalis & Would not form a model. & & & & & \\
\hline \multirow[t]{4}{*}{ Rhinichthys atratulus } & $\begin{array}{l}\text { rapid visual habitat } \\
\text { assessment }\end{array}$ & 4.25 & 23 & 0.21 & + & 0.052 \\
\hline & canopy cover & 13.81 & 23 & 0.18 & - & 0.001 \\
\hline & PC 3 & 3.79 & 23 & 0.10 & - & 0.066 \\
\hline & model & 6.30 & 23 & 0.49 & & 0.004 \\
\hline \multirow[t]{3}{*}{ Clinostomus funduloides } & PC1 & 9.40 & 23 & 0.21 & + & 0.006 \\
\hline & PC3 & 5.16 & 23 & 0.16 & + & 0.034 \\
\hline & model & 6.00 & 23 & 0.36 & & 0.009 \\
\hline \multirow[t]{4}{*}{ Semotilus atromaculatus } & CC & 26.52 & 23 & 0.31 & - & $<0.001$ \\
\hline & PC3 & 5.72 & 23 & 0.21 & - & 0.027 \\
\hline & $\begin{array}{l}\text { rapid visual habitat } \\
\text { assessment }\end{array}$ & 5.54 & 23 & 0.10 & + & 0.029 \\
\hline & model & 11.09 & 23 & 0.62 & & $<0.001$ \\
\hline
\end{tabular}


$\underline{\text { Table } 15 \text { continued }}$

\begin{tabular}{lllllll}
\hline$y$-response & habitat variable & $f$-value & $d f$ & $r^{2}$ & direction & $p$-value \\
\hline \multirow{2}{*}{ Catostomus commersoni } & PC3 & 9.35 & 23 & 0.22 & + & 0.006 \\
& PC1 & 4.16 & 23 & 0.13 & + & 0.054 \\
& model & 5.63 & 23 & 0.35 & 0.011 \\
\hline
\end{tabular}


Table 16: Results from step-wise multiple linear regression analysis between three significant habitat principal components as well as three habitat variables not included in the principal components analysis and fish community variables on stream reaches upstream of culverts ( $\mathrm{n}=$ 47). Principal component 1 (PC 1) is a positive habitat size component and both principal component 2 (PC 2) and principal component 3 (PC 3) are positive habitat complexity gradients.

\begin{tabular}{|c|c|c|c|c|c|c|}
\hline$y$-response & habitat variable & f-value & $d f$ & $r^{2}$ & direction & $p$-value \\
\hline \multirow{5}{*}{ species richness } & PC 1 & 45.47 & 46 & 0.49 & + & $<0.001$ \\
\hline & PC 3 & 14.64 & 46 & 0.07 & + & $<0.001$ \\
\hline & PC 2 & 10.37 & 46 & 0.05 & - & 0.003 \\
\hline & distance to the mainstem & 6.03 & 46 & 0.05 & - & 0.018 \\
\hline & model & 20.82 & 46 & 0.66 & & $<0.001$ \\
\hline \multirow[t]{3}{*}{ Cottus bairdii } & PC 1 & 24.88 & 46 & 0.31 & + & $<0.001$ \\
\hline & $\mathrm{CC}$ & 4.77 & 46 & 0.07 & + & 0.034 \\
\hline & model & 13.20 & 46 & 0.38 & & $<0.001$ \\
\hline \multirow[t]{4}{*}{ Salvelinus fontinalis } & $\begin{array}{l}\text { rapid visual habitat } \\
\text { assessment }\end{array}$ & 9.36 & 46 & 0.14 & + & 0.004 \\
\hline & PC 2 & 5.00 & 46 & 0.06 & - & 0.031 \\
\hline & distance to the mainstem & 2.45 & 46 & 0.04 & - & 0.125 \\
\hline & model & 4.61 & 46 & 0.24 & & 0.007 \\
\hline \multirow[t]{5}{*}{ Rhinichthys atratulus } & canopy cover & 15.85 & 46 & 0.41 & - & $<0.001$ \\
\hline & PC 1 & 7.05 & 46 & 0.06 & + & 0.011 \\
\hline & $\begin{array}{l}\text { rapid visual habitat } \\
\text { assessment }\end{array}$ & 7.62 & 46 & 0.03 & - & 0.009 \\
\hline & distance to the mainstem & 3.45 & 46 & 0.04 & + & 0.070 \\
\hline & model & 12.24 & 46 & 0.54 & & $<0.001$ \\
\hline
\end{tabular}


Table 16 continued

\begin{tabular}{|c|c|c|c|c|c|c|}
\hline$y$-response & habitat variable & $f$-value & $d f$ & $r^{2}$ & direction & $p$-value \\
\hline \multirow[t]{6}{*}{ Clinostomus funduloides } & PC3 & 14.53 & 46 & 0.15 & + & 0.001 \\
\hline & distance to the mainstem & 7.64 & 46 & 0.15 & - & 0.009 \\
\hline & PC2 & 10.45 & 46 & 0.10 & - & 0.002 \\
\hline & $\mathrm{PC} 1$ & 5.46 & 46 & 0.04 & + & 0.024 \\
\hline & $\begin{array}{l}\text { rapid visual habitat } \\
\text { assessment }\end{array}$ & 2.44 & 46 & 0.03 & - & 0.126 \\
\hline & model & 7.29 & 46 & 0.47 & & $<0.001$ \\
\hline \multirow[t]{3}{*}{ Semotilus atromaculatus } & $\mathrm{CC}$ & 34.44 & 46 & 0.46 & - & $<0.001$ \\
\hline & $\mathrm{PC} 2$ & 3.06 & 46 & 0.03 & - & 0.087 \\
\hline & model & 21.83 & 46 & 0.50 & & $<0.001$ \\
\hline \multirow[t]{4}{*}{ Catostomus commersoni } & PC3 & 8.37 & 46 & 0.14 & + & 0.006 \\
\hline & $\mathrm{PC} 2$ & 10.41 & 46 & 0.08 & - & 0.002 \\
\hline & DMS & 8.79 & 46 & 0.07 & - & 0.005 \\
\hline & model & 6.02 & 46 & 0.30 & & 0.002 \\
\hline
\end{tabular}


Table 17: Results from pairwise two-tailed wilcoxon signed ranks tests on stream habitat variables for: a) richness group 1 sites (sites where a culvert effect was observed) and b) richness group 2 sites (sites where no culvert effect was observed). The bonferroni-corrected alpha level for significance for both groups of tests was 0.01 . PC $1=$ principal component 1 ; PC 2 = principal component 2; PC 3 = principal component 3.

a.

\begin{tabular}{|c|c|c|c|c|c|c|}
\hline \multirow[b]{2}{*}{ Variable } & \multicolumn{2}{|c|}{ mean(standard error) } & \multirow[b]{2}{*}{$\%$ difference } & \multirow[b]{2}{*}{ W statistic } & \multirow[b]{2}{*}{$d f$} & \multirow[b]{2}{*}{$p$-value } \\
\hline & US & $D S$ & & & & \\
\hline PC 1 & $-0.370(0.458)$ & $-0.200(0.478)$ & $\mathrm{n} / \mathrm{a}$ & 9.0 & 9 & 0.13 \\
\hline PC 2 & $-0.567(0.327)$ & $-0.926(0.385)$ & $\mathrm{n} / \mathrm{a}$ & 13.0 & 9 & 0.30 \\
\hline PC 3 & $-0.025(0.315)$ & $-0.209(0.196)$ & $\mathrm{n} / \mathrm{a}$ & 15.0 & 9 & 0.43 \\
\hline slope & $7.3(1.0)$ & $4.1(0.9)$ & 76.5 & 1.0 & 8 & 0.02 \\
\hline
\end{tabular}

b.

\begin{tabular}{lcccccc} 
& \multicolumn{2}{c}{ mean(standard error) } & & & & \\
Variable & US & DS & \% difference & W statistic & $d f$ & $p$-value \\
\cline { 2 - 6 } PC 1 & $-0.793(0.537)$ & $-1.015(0.789)$ & n/a & 13.0 & 8 & 0.55 \\
PC 2 & $0.292(0.435)$ & $0.349(1.020)$ & n/a & 10.0 & 8 & 0.31 \\
PC 3 & $-0.106(0.128)$ & $0.549(0.558)$ & n/a & 9.0 & 8 & 0.25 \\
slope & $7.9(1.9)$ & $8.3(2.4)$ & -5.7 & 19.0 & 8 & 0.95 \\
\hline
\end{tabular}


Table 18: Results from pairwise two-tailed wilcoxon signed ranks tests on stream habitat variables for: a) blacknose dace density group 1 sites (sites where a culvert effect was observed) and b) blacknose dace density group 2 sites (sites where no culvert effect was observed). The bonferroni-corrected alpha level for significance for both groups of tests is 0.02 . PC $1=$ principal component 1.

a.

\begin{tabular}{lcccccc} 
& \multicolumn{2}{c}{ mean(standard error) } & & & & \\
\cline { 2 - 3 } Variable & US & $D S$ & \% difference & W statistic & $d f$ & $p$-value \\
\hline canopy cover & $88.5(2.4)$ & $81.3(7.7)$ & 8.8 & 24.0 & 9 & 0.77 \\
PC 1 & $0.988(0.4)$ & $1.333(0.3)$ & n/a & 10.0 & 9 & 0.08 \\
$\begin{array}{l}\text { rapid visual habitat } \\
\text { assessment }\end{array}$ & $156(4.6)$ & $159(3.0)$ & -1.8 & 22.5 & 9 & 0.70 \\
\hline
\end{tabular}

b.

\begin{tabular}{|c|c|c|c|c|c|c|}
\hline \multirow[b]{2}{*}{ Variable } & \multicolumn{2}{|c|}{ mean(standard error) } & \multirow[b]{2}{*}{$\%$ difference } & \multirow[b]{2}{*}{ W statistic } & \multirow[b]{2}{*}{$d f$} & \multirow[b]{2}{*}{$p$-value } \\
\hline & US & $D S$ & & & & \\
\hline canopy cover & $82.5(4.7)$ & $91.1(1.6)$ & -9.4 & 25.0 & 12 & 0.17 \\
\hline PC 1 & $-0.665(0.5)$ & $-0.773(0.5)$ & $\mathrm{n} / \mathrm{a}$ & 41.0 & 12 & 0.79 \\
\hline $\begin{array}{l}\text { rapid visual habitat } \\
\text { assessment }\end{array}$ & $150(3.7)$ & $141(9.0)$ & 6.0 & 37.0 & 12 & 0.59 \\
\hline
\end{tabular}


Table 19: Results from linear regressions between pairwise richness differences (below culvert above culvert) and the listed habitat variables. Variables with significant correlations are bolded.

\begin{tabular}{|c|c|c|c|}
\hline variable & $R^{2}$ & $n$ & $p$ \\
\hline average current velocity & 0.03 & 23 & 0.415 \\
\hline basin area & 0.06 & 23 & 0.273 \\
\hline canopy cover & 0.00 & 23 & 0.873 \\
\hline CV of average current velocity & 0.22 & 23 & 0.025 \\
\hline CV of depth & 0.12 & 23 & 0.114 \\
\hline depth & 0.01 & 23 & 0.657 \\
\hline$D_{50}$ & 0.12 & 23 & 0.111 \\
\hline distance to fish cover & 0.07 & 23 & 0.236 \\
\hline distance to the mainstem & 0.20 & 23 & 0.033 \\
\hline large woody debris volume per $50 \mathrm{~m}$ of stream & 0.04 & 23 & 0.342 \\
\hline pool area per $50 \mathrm{~m}$ of stream & 0.03 & 23 & 0.407 \\
\hline principal component 1 & 0.00 & 23 & 0.907 \\
\hline principal component 2 & 0.07 & 23 & 0.229 \\
\hline principal component 3 & 0.09 & 23 & 0.156 \\
\hline pool-riffle ratio & 0.16 & 23 & 0.061 \\
\hline rapid visual habitat assessment & 0.08 & 23 & 0.191 \\
\hline percent silt/sand & 0.01 & 23 & 0.680 \\
\hline slope & 0.04 & 23 & 0.390 \\
\hline
\end{tabular}


Table 20: Results from linear regressions between pairwise blacknose dace (Rhinichthys atratulus) density differences (below culvert - above culvert) and the listed habitat variables.

\begin{tabular}{|c|c|c|c|}
\hline variable & $R^{2}$ & $n$ & $p$ \\
\hline average current velocity & 0.06 & 23 & 0.279 \\
\hline basin area & 0.05 & 23 & 0.325 \\
\hline canopy cover & 0.00 & 23 & 0.920 \\
\hline CV of average current velocity & 0.00 & 23 & 0.939 \\
\hline CV of depth & 0.04 & 23 & 0.385 \\
\hline depth & 0.05 & 23 & 0.325 \\
\hline$D_{50}$ & 0.24 & 23 & 0.018 \\
\hline distance to fish cover & 0.04 & 23 & 0.370 \\
\hline distance to the mainstem & 0.00 & 23 & 0.851 \\
\hline large woody debris volume per $50 \mathrm{~m}$ of stream & 0.00 & 23 & 0.879 \\
\hline pool area per $50 \mathrm{~m}$ of stream & 0.10 & 23 & 0.140 \\
\hline principal component 1 & 0.11 & 23 & 0.126 \\
\hline principal component 2 & 0.04 & 23 & 0.335 \\
\hline principal component 3 & 0.06 & 23 & 0.248 \\
\hline pool-riffle ratio & 0.00 & 23 & 0.774 \\
\hline rapid visual habitat assessment & 0.02 & 23 & 0.583 \\
\hline percent silt/sand & 0.04 & 23 & 0.379 \\
\hline slope & 0.01 & 23 & 0.731 \\
\hline
\end{tabular}


Table 21: Results from Kolmogorov-Smirnov tests comparing upstream and downstream cumulative proportional curves for the following combinations of variables.

\begin{tabular}{llccc}
\hline \multirow{2}{*}{$\begin{array}{l}\text { y-variable } \\
\text { richness }\end{array}$} & b-variable & $D$-statistic & $d f$ & $p$-value \\
& slope & 0.12 & 23 & 0.708 \\
blacknose dace density & basin area & 0.1 & 23 & 0.787 \\
& slope & 0.15 & 23 & 0.583 \\
mottled sculpin density & basin area & 0.34 & 23 & 0.062 \\
& slope & 0.15 & 23 & 0.583 \\
brook trout density & basin area & 0.15 & 23 & 0.583 \\
& slope & 0.20 & 23 & 0.399 \\
\hline
\end{tabular}




\section{Figures}

Figure 20: Map of the upper Cheat River basin, West Virginia, except the Blackwater River, with the three study area sections outlined in bold. Culverts locations are represented by black dots. Specifically, the study area consisted of the following study sections: lower Dry Fork, Glady Fork, and upper Dry Fork (including upper Dry Fork and Gandy Creek).

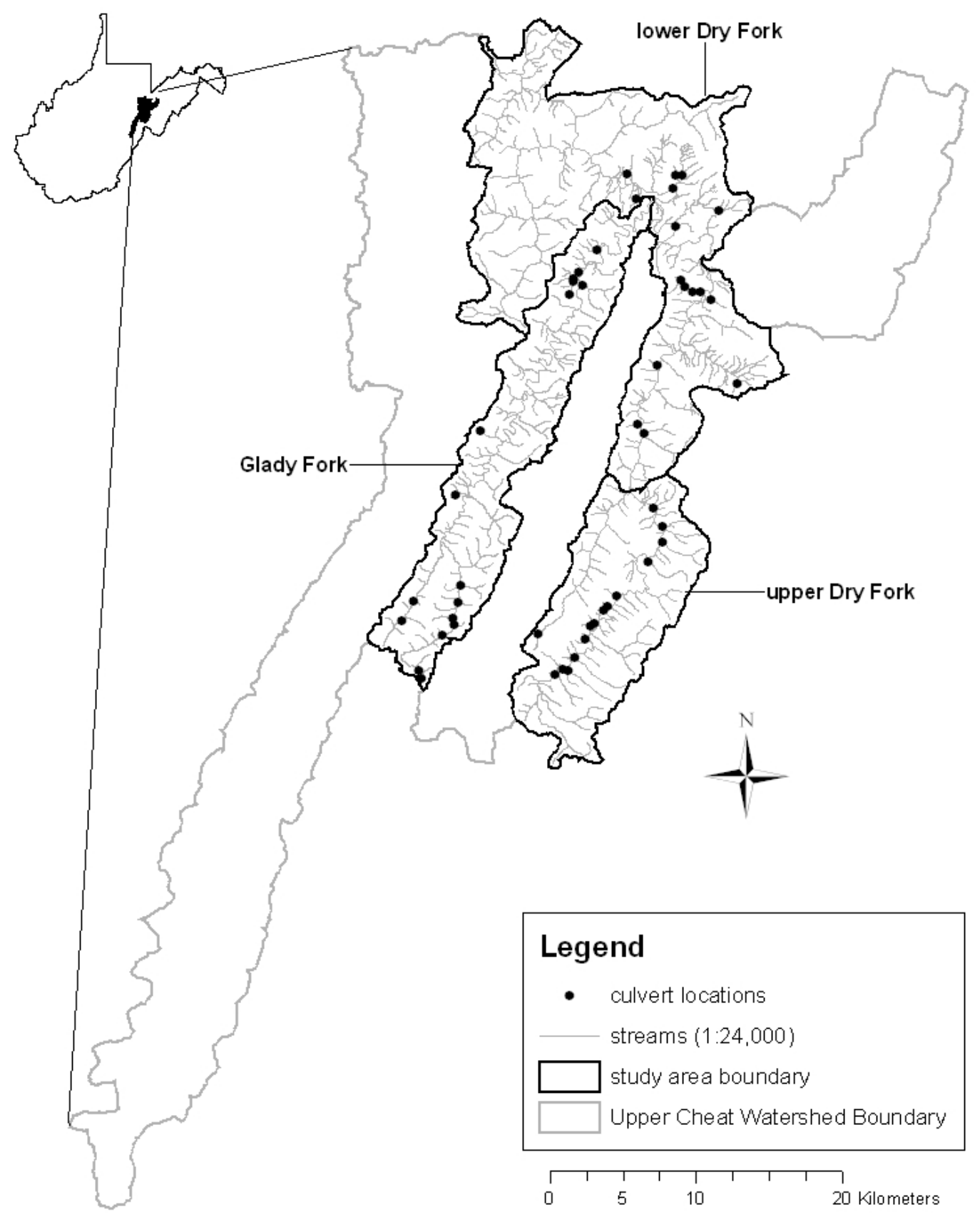


Figure 21: Sampling scheme for water quality, habitat, and fish abundance data sampling performed at each culvert. Hypothetical sampling reaches are highlighted shaded light gray.

\section{upstream}

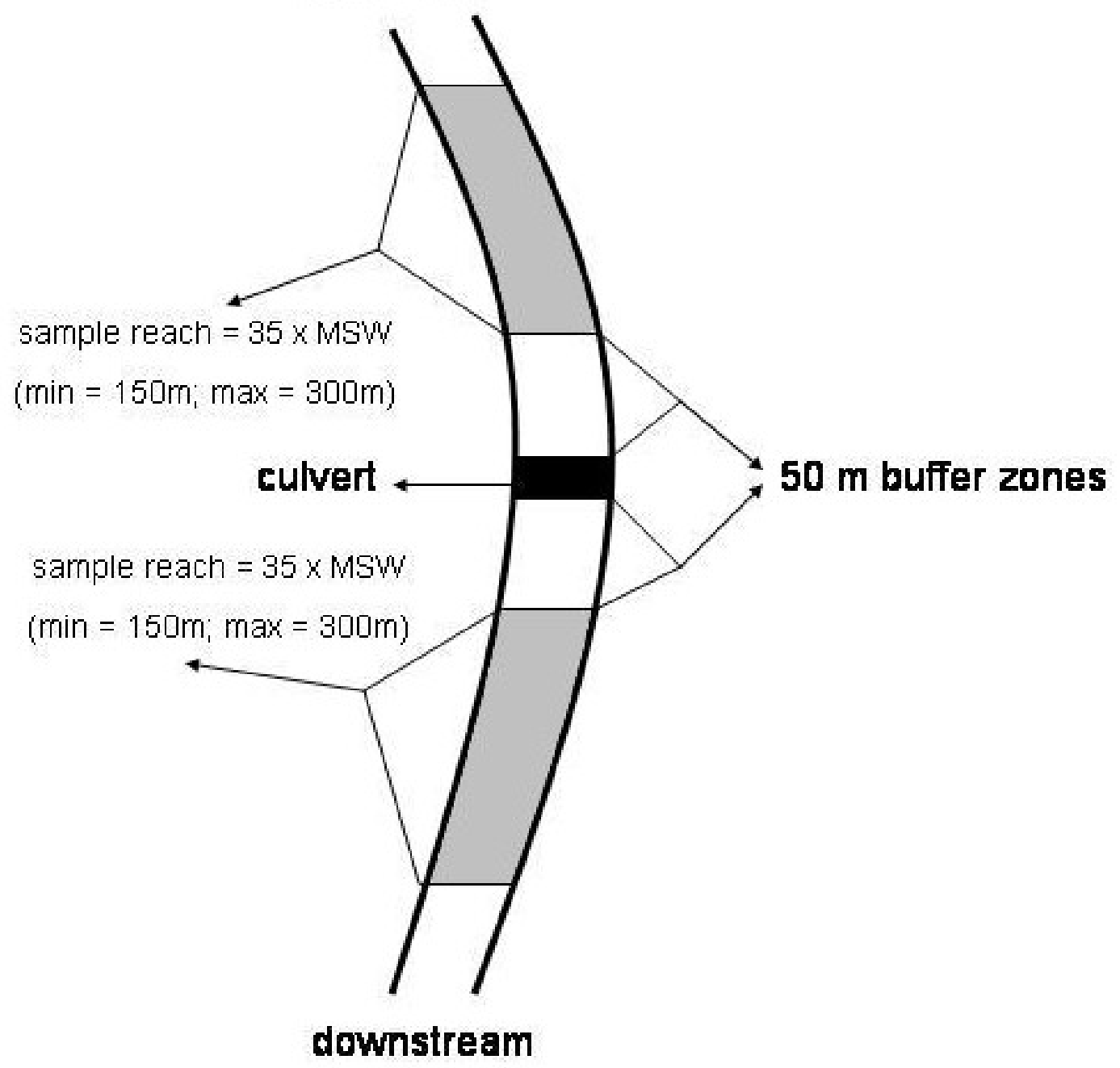


Figure 22: a) Cumulative species count for both above and below the culvert reaches plotted against log-transformed basin area $\left(\mathrm{km}^{2}\right)$. Cumulative proportional species count for both above and below reaches plotted against: b) basin area $\left(\mathrm{km}^{2}\right)$ and c) slope (\%) for all sites sampled upstream and downstream of the culvert, except one outlier $(n=23)$. The cumulative species count at a given reach is defined as the sum of the species richness at that reach plus the total sum of the species richness values at all smaller reaches. In other words species were counted each time they were found at a new reach.
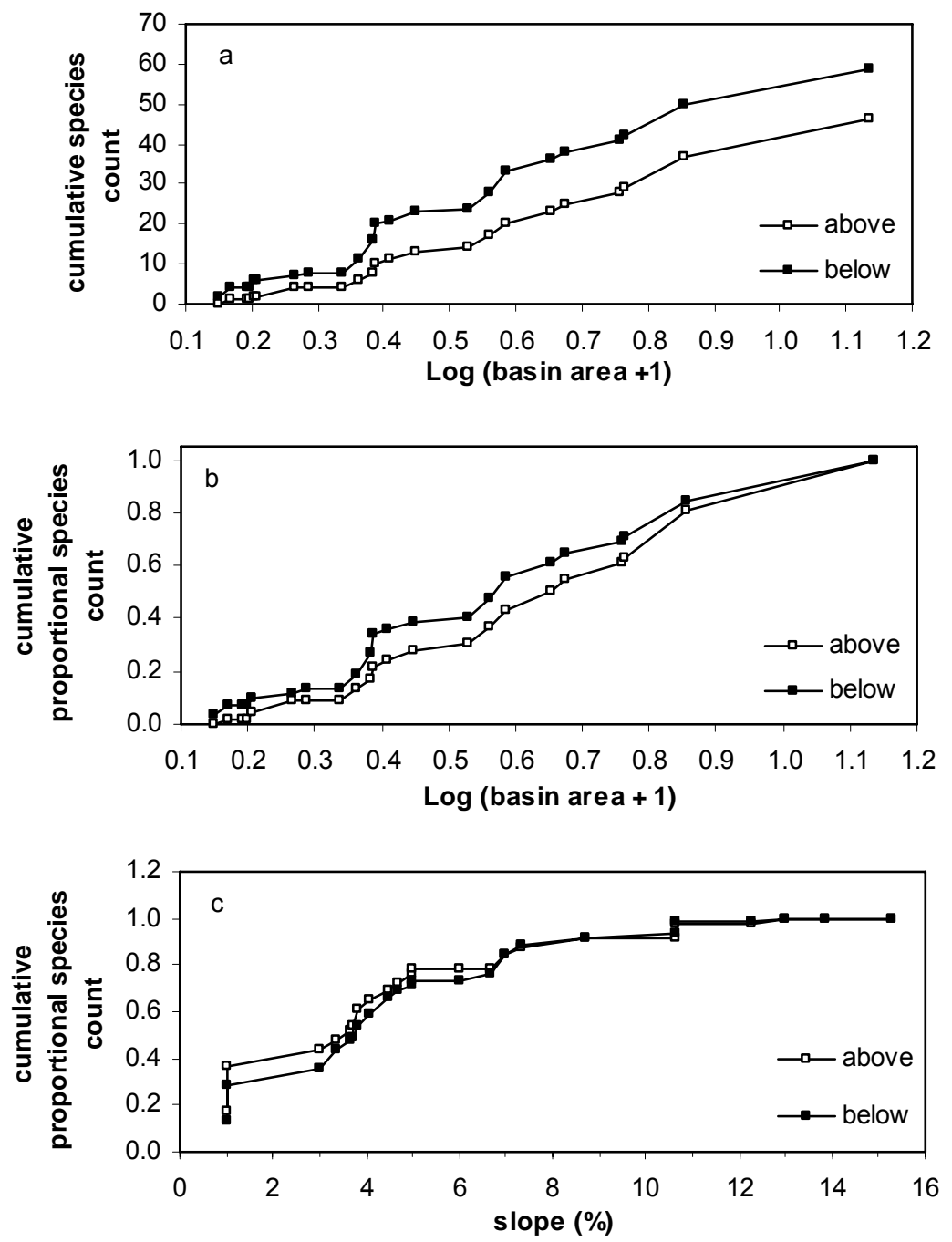
Figure 23: Pairwise differences (downstream reach - upstream reach) in a) species richness, b) mottled sculpin (Cottus bairdi) density, c) brook trout (Salvelinus fontinalis) density, d) blacknose dace (Rhinichthys atratulus) density, e) creek chub (Semotilus atromaculatus) density, f) white sucker (Catostomus commersoni) density, and g) rosyside (Clinostomus funduloides) dace density plotted against basin area for all sites sampled upstream of and downstream of the culvert, except on outlier $(n=23)$
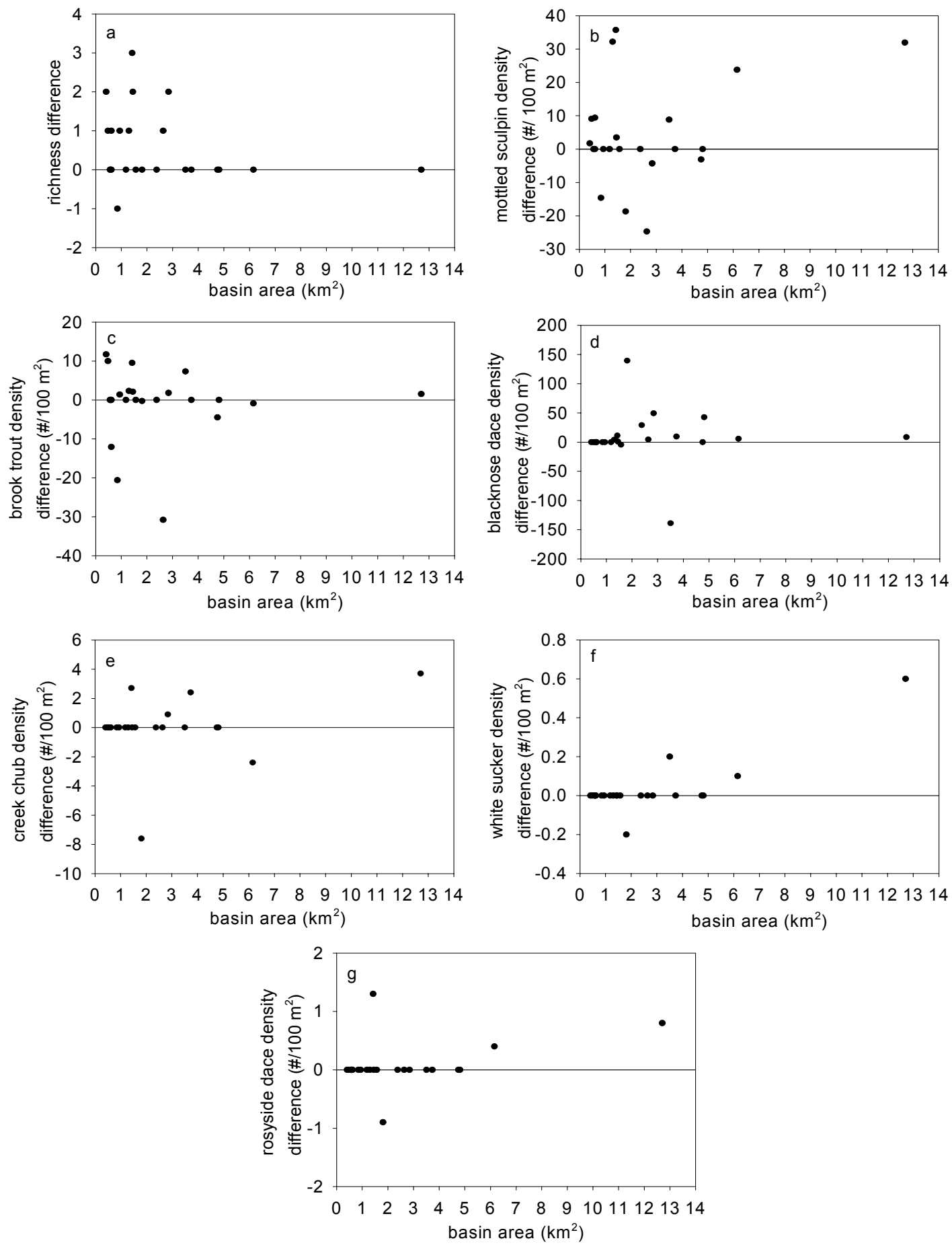
Figure 24: a) Cumulative blacknose dace (Rhynichthys atratulus) density plotted separately for above and below the culvert reaches against basin area $\left(\mathrm{km}^{2}\right)$. Cumulative proportional blacknose dace density plotted for both above and below the culvert reaches against: b) basin area $\left(\mathrm{km}^{2}\right)$ and c) slope (\%).
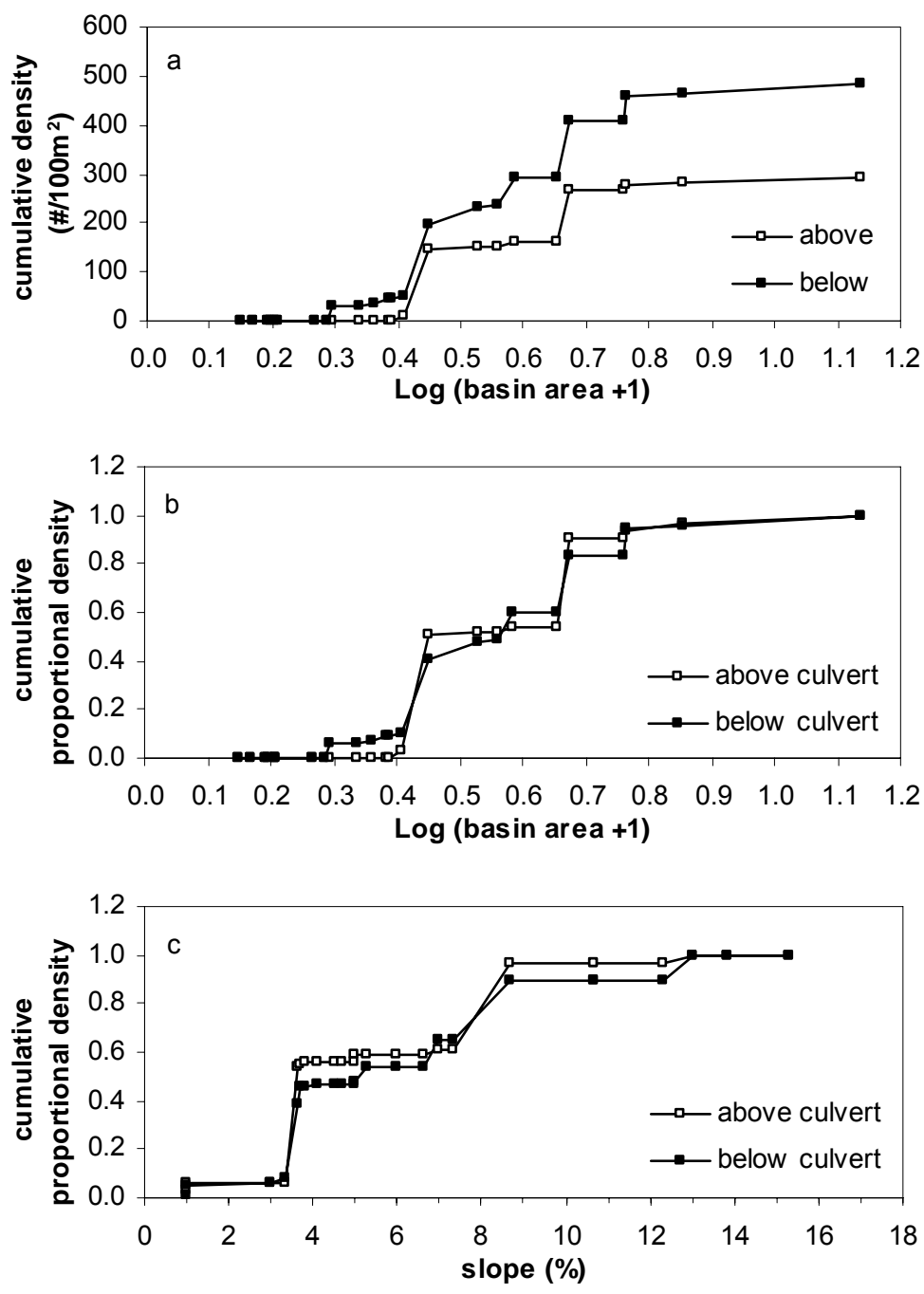
Figure 25: a) Cumulative mottled sculpin (Cottus bairdi) density plotted against basin area $\left(\mathrm{km}^{2}\right)$ for both above and below the culvert reaches. Cumulative proportional mottled sculpin density plotted separately for above and below the culvert reaches against: b) basin area $\left(\mathrm{km}^{2}\right)$ and c) slope (\%).
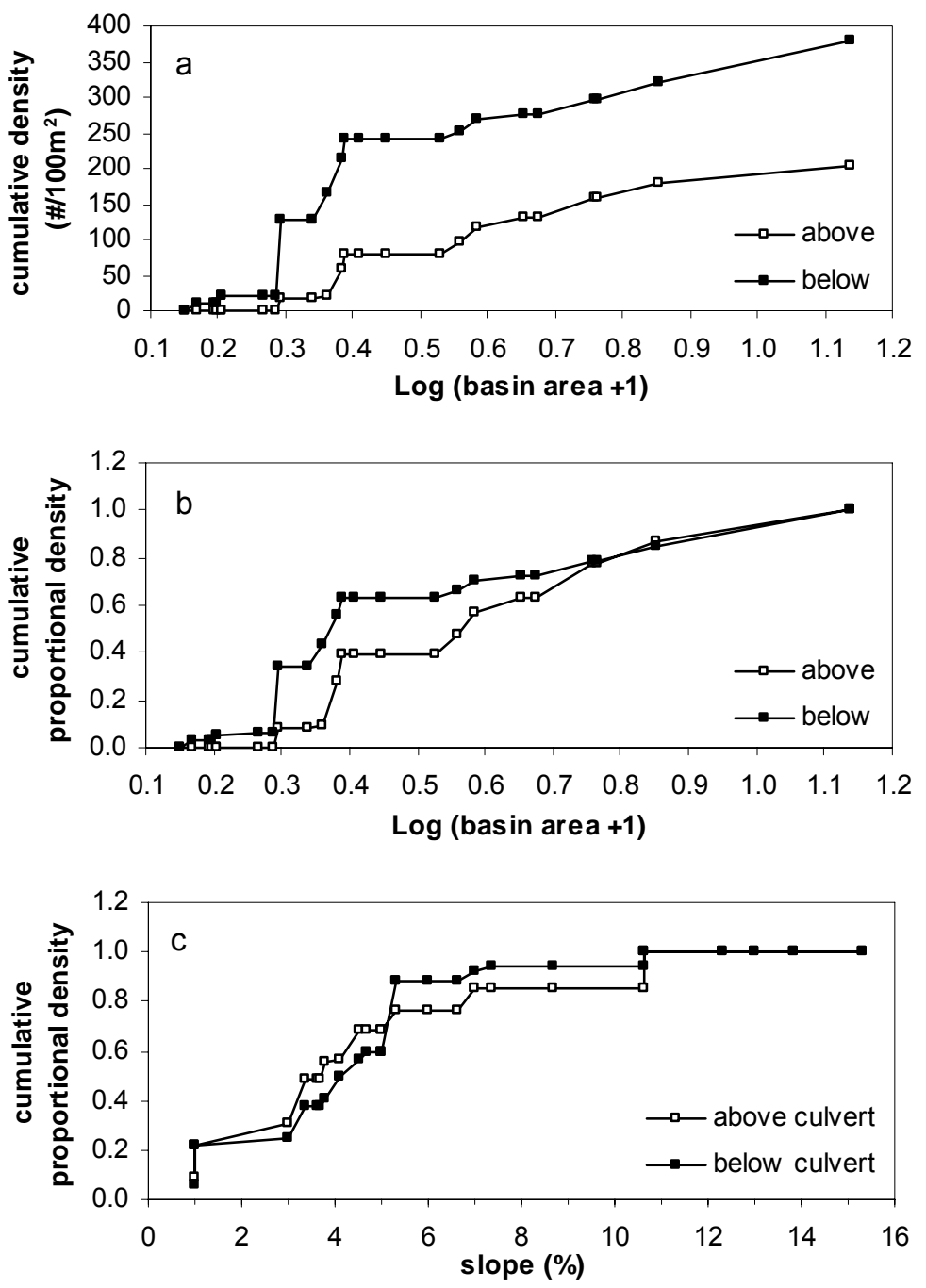
Figure 26: a) Cumulative brook trout (Salvelinus fontinalis) density plotted separately for above and below the culvert reaches against basin area $\left(\mathrm{km}^{2}\right)$. Cumulative proportional brook trout density plotted separately for above and below the culvert reaches against: b) basin area $\left(\mathrm{km}^{2}\right)$ and c) slope (\%).
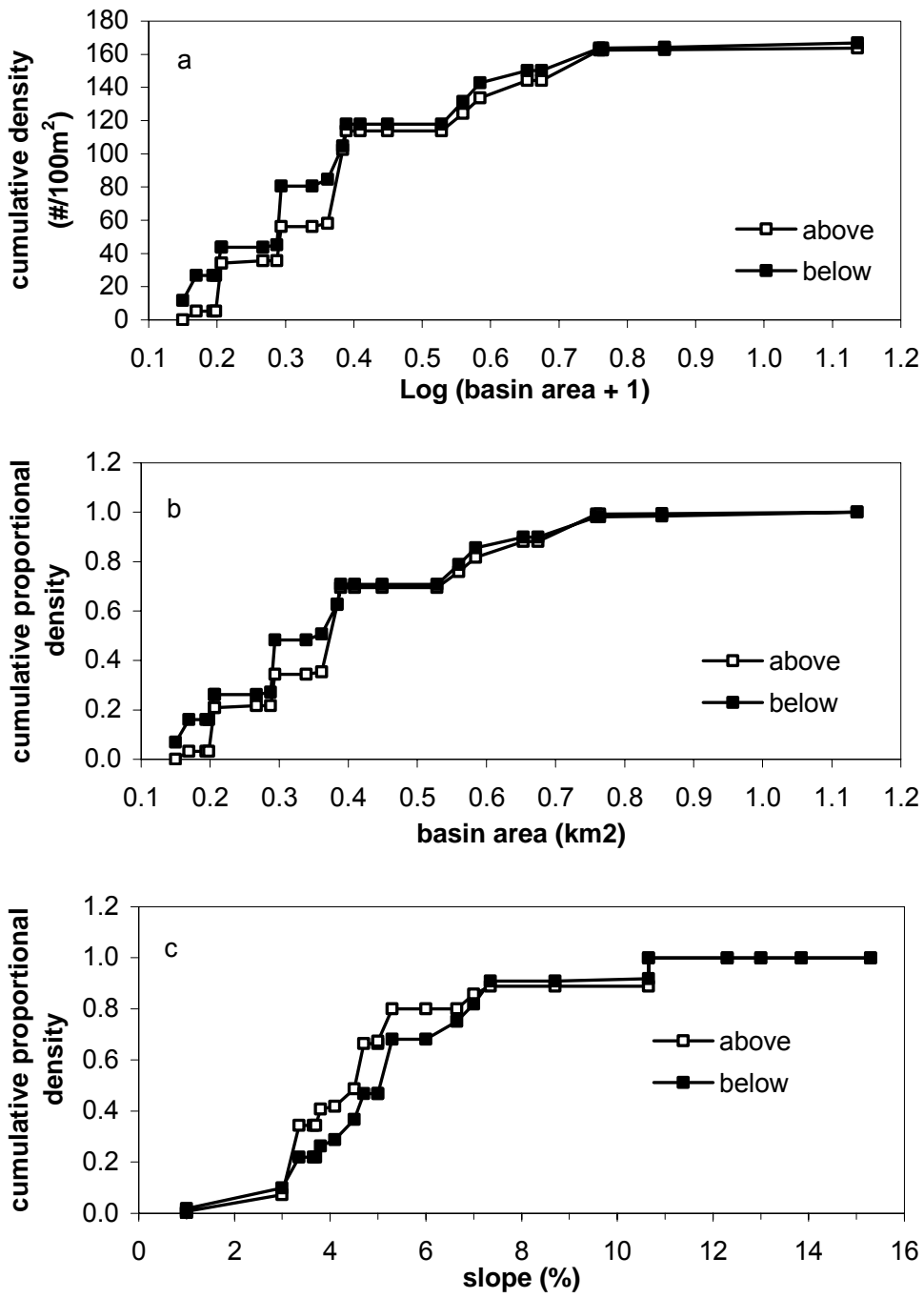
Figure 27: Observed versus expected values, given downstream habitat models and upstream habitat values, for the following fish community variables: a) species richness, b) mottled sculpin (Cottus bairdi) density, c) brook trout (Salvelinus fontinalis) density, d) blacknose dace (Rhinichthys atratulus) density, e) creek chub (Semotilus atromaculatus) density, f) white sucker (Catostomus commersoni) density, and g) rosyside (Clinostomus funduloides) dace density. Each graph includes separate plots for downstream and upstream reaches.
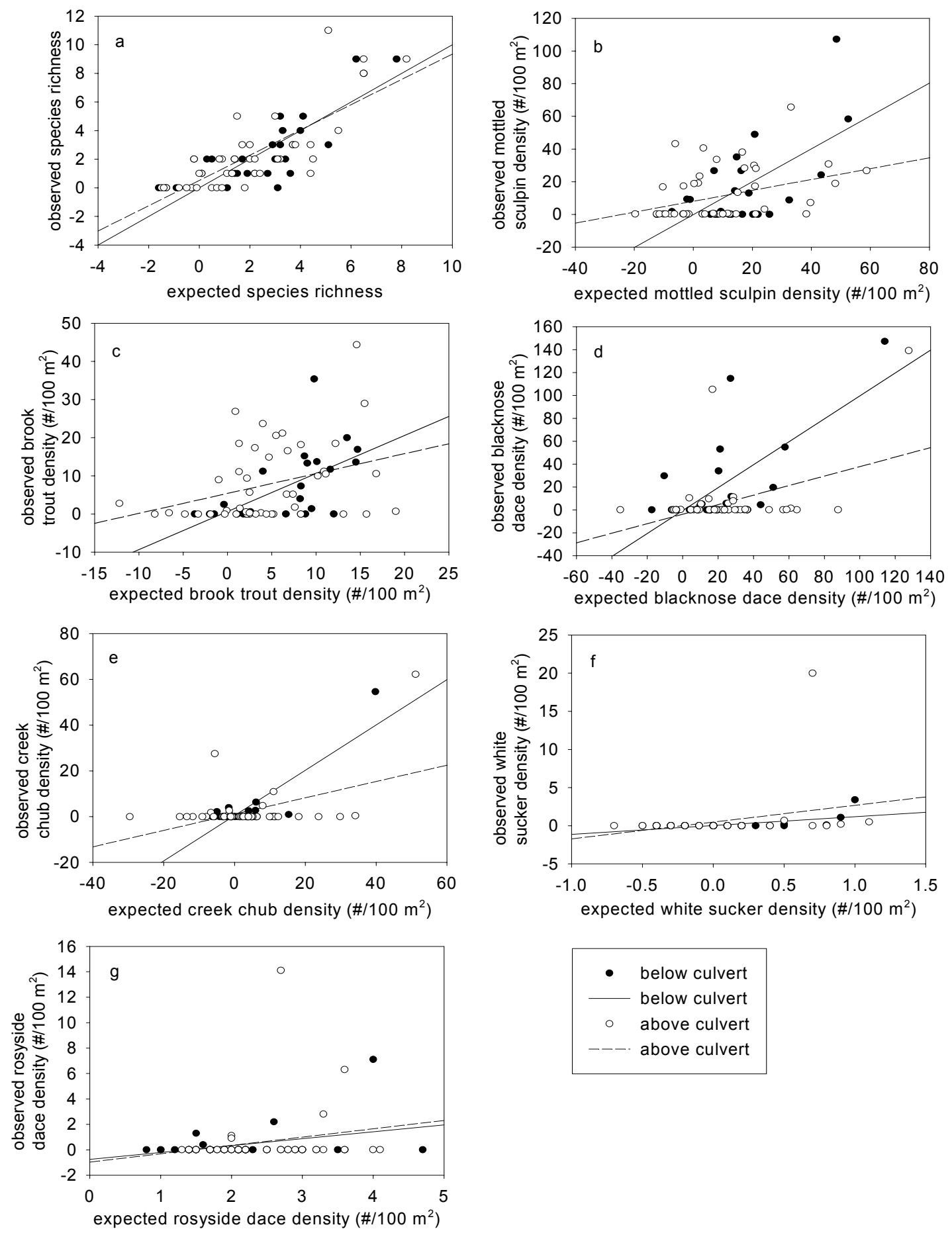
Figure 28: Pairwise species richness differences (downstream of culvert - upstream of culvert) divided into three culvert effect groups. Group 1 includes all small basin area $\left(<3.5 \mathrm{~km}^{2}\right)$ culvert sites where a positive richness difference was observed. Group 2 includes all small basin area culvert sites where no difference or a negative difference was observed. Group 3 includes all large basin area $\left(\geq 3.5 \mathrm{~km}^{2}\right)$ culvert sites.

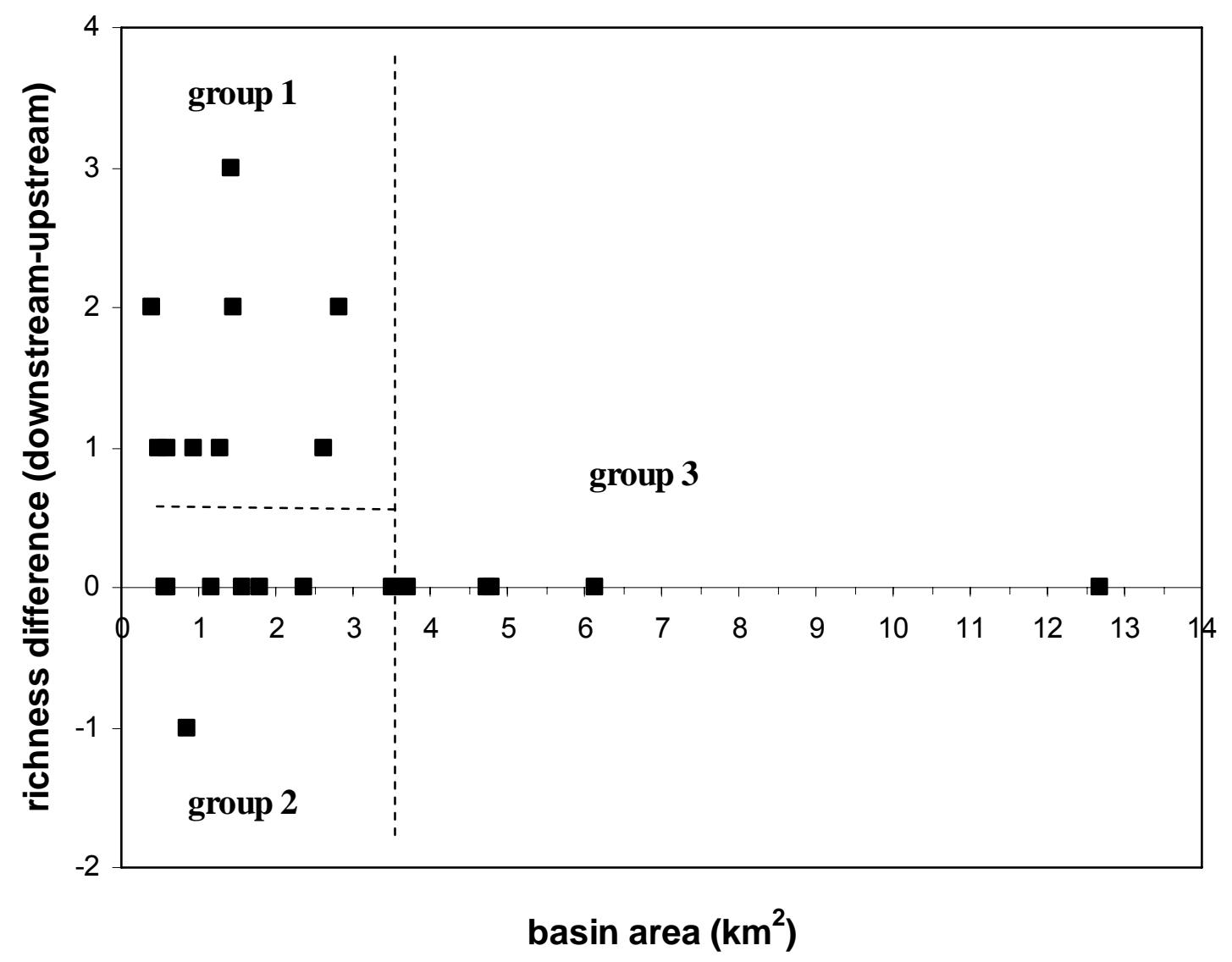


Figure 29: Pairwise differences (downstream of culvert - upstream of culvert) in blacknose dace (Rhinichthys atratulus) density plotted against basin area. Group 1 includes culverts with a positive difference and group 2 includes culverts with no difference or a negative difference.

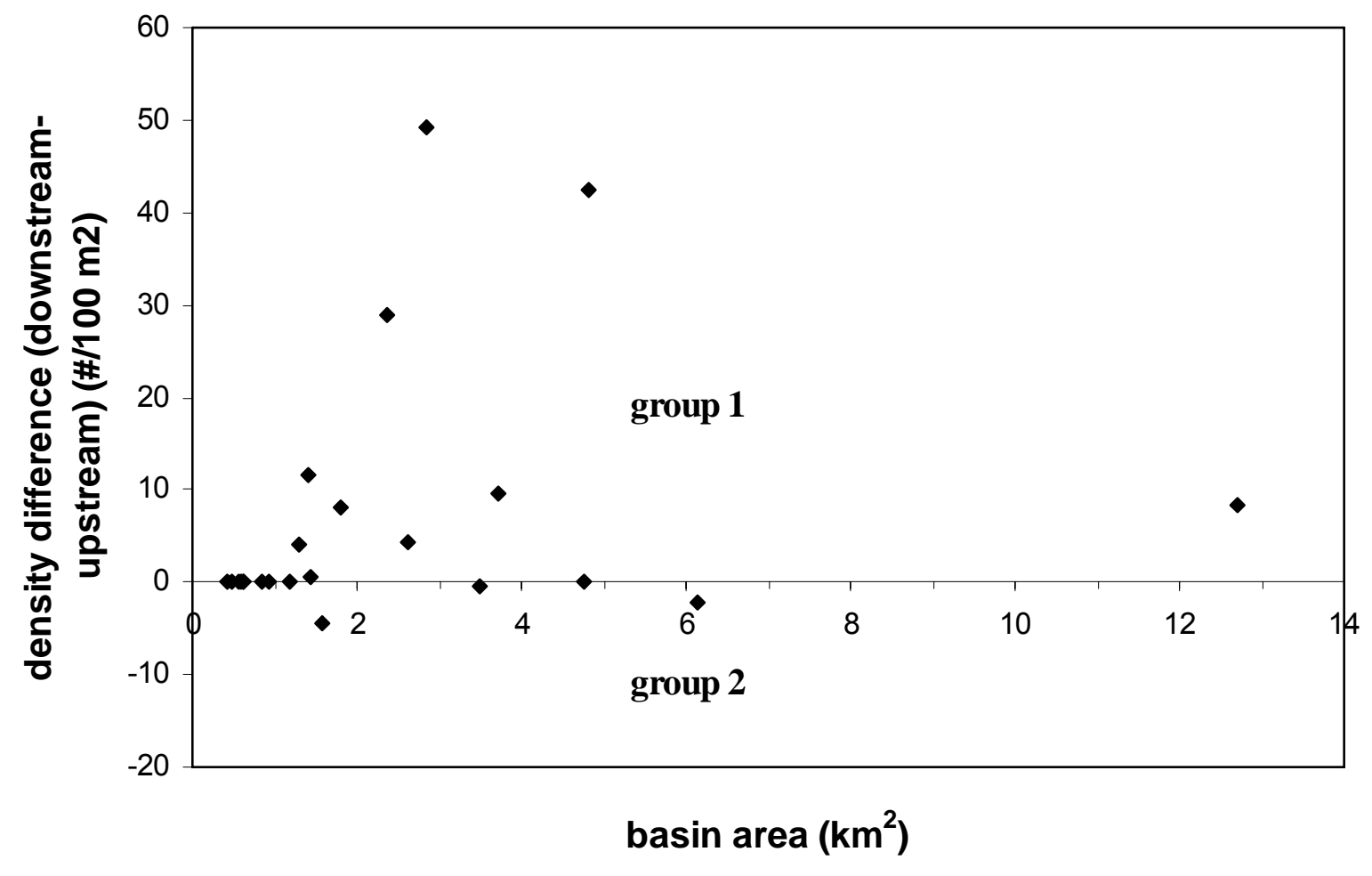


Figure 30: Richness difference (downstream of culvert-upstream of culvert) plotted against stream-distance from the culvert to the nearest mainstem point (nearest point draining over 15 $\mathrm{km}^{2}$ ) for all sites sampled both upstream and downstream of the culvert, except one outlier ( $\mathrm{n}=$ 23). Richness difference was positively correlated with stream distance to the mainstem.

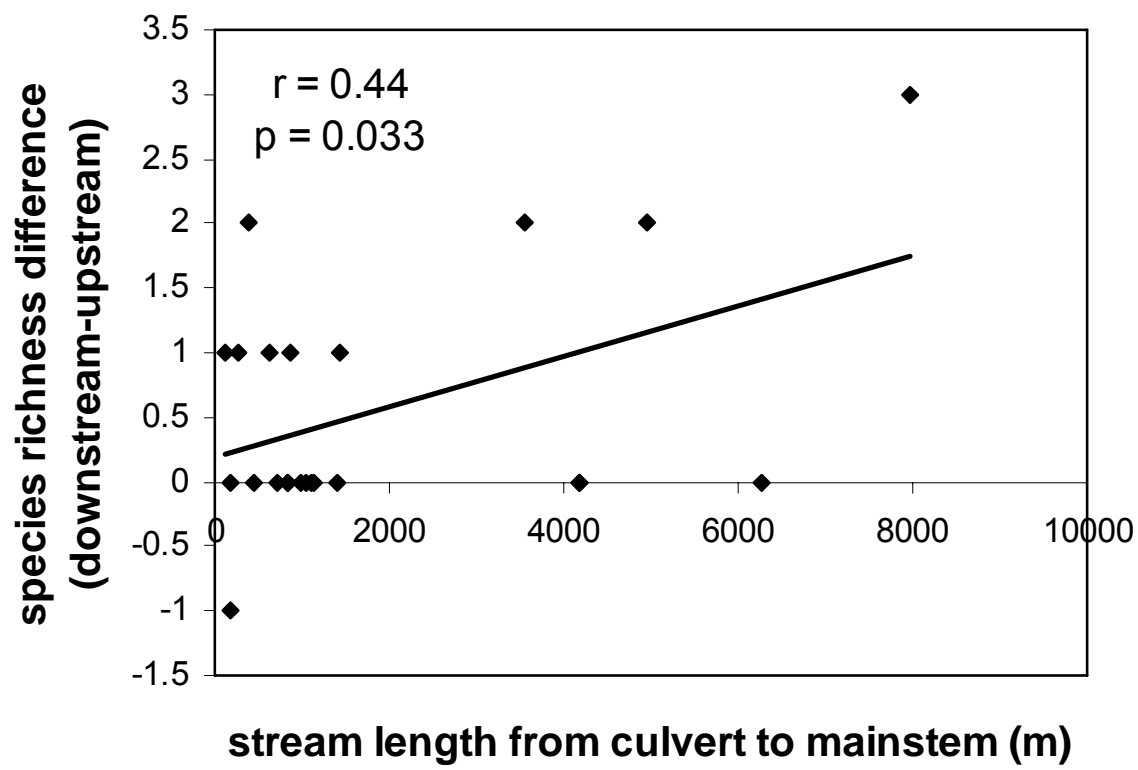

Figure 31: Richness difference (downstream of culvert- upstream of culvert) plotted against the coefficient of variation of average current velocity for all sites sampled both above and below the culvert, except on outlier $(n=23)$. Richness difference was negatively correlated with longitudinal variation in current velocity.

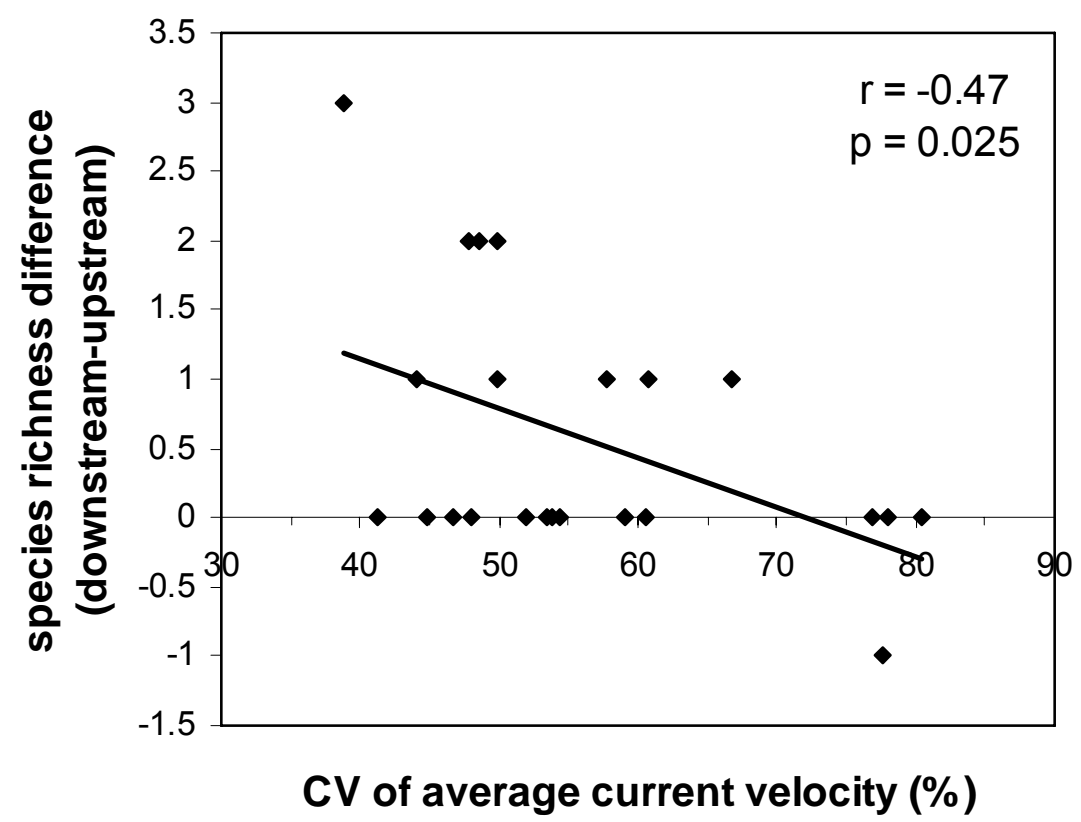


Figure 32: Blacknose dace density difference (downstream of culvert - upstream of culvert) plotted against median substrate size $\left(\mathrm{D}_{50}\right)$ for all sites sampled both upstream and downstream of the culvert, except one outlier $(n=23)$. Differences in blacknose dace density were positively correlated with $\mathrm{D}_{50}$.

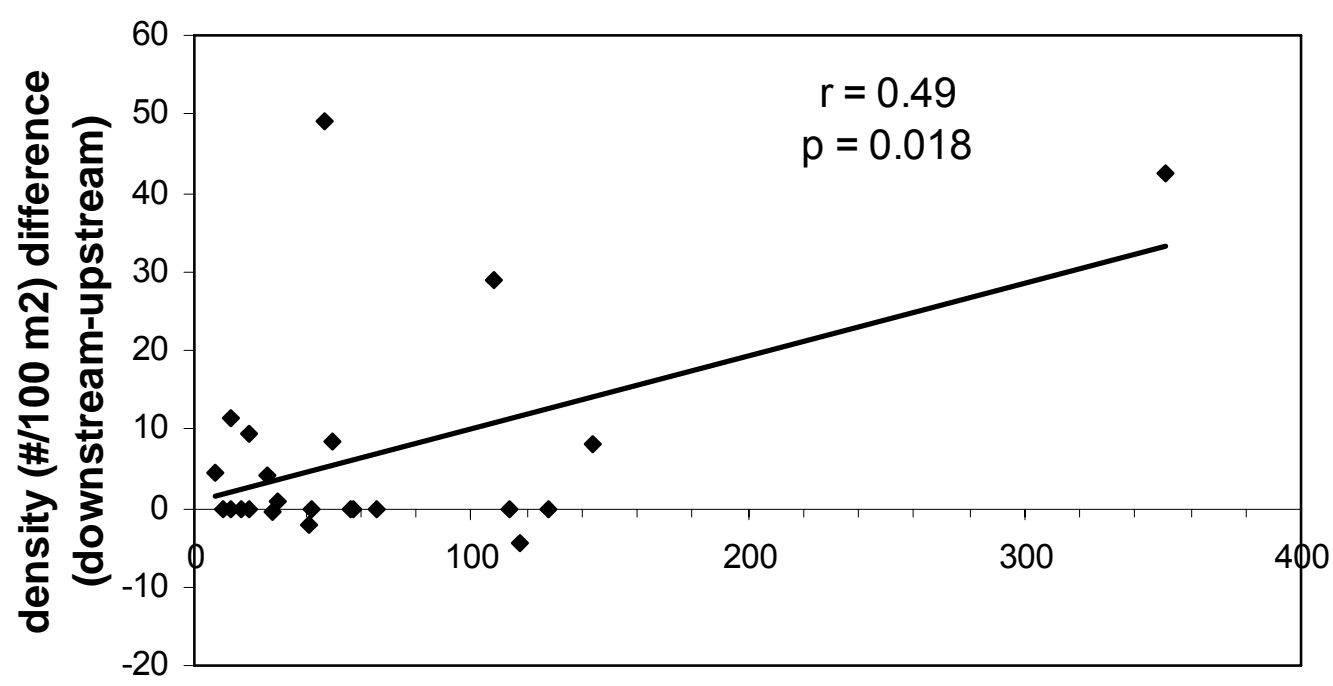

median substrate size $(\mathrm{mm})$

Figure 33: Blacknose dace density difference (downstream of culvert - upstream of culvert) plotted against median substrate size $\left(D_{50}\right)$ after the removal of an outlier site $(n=22)$.

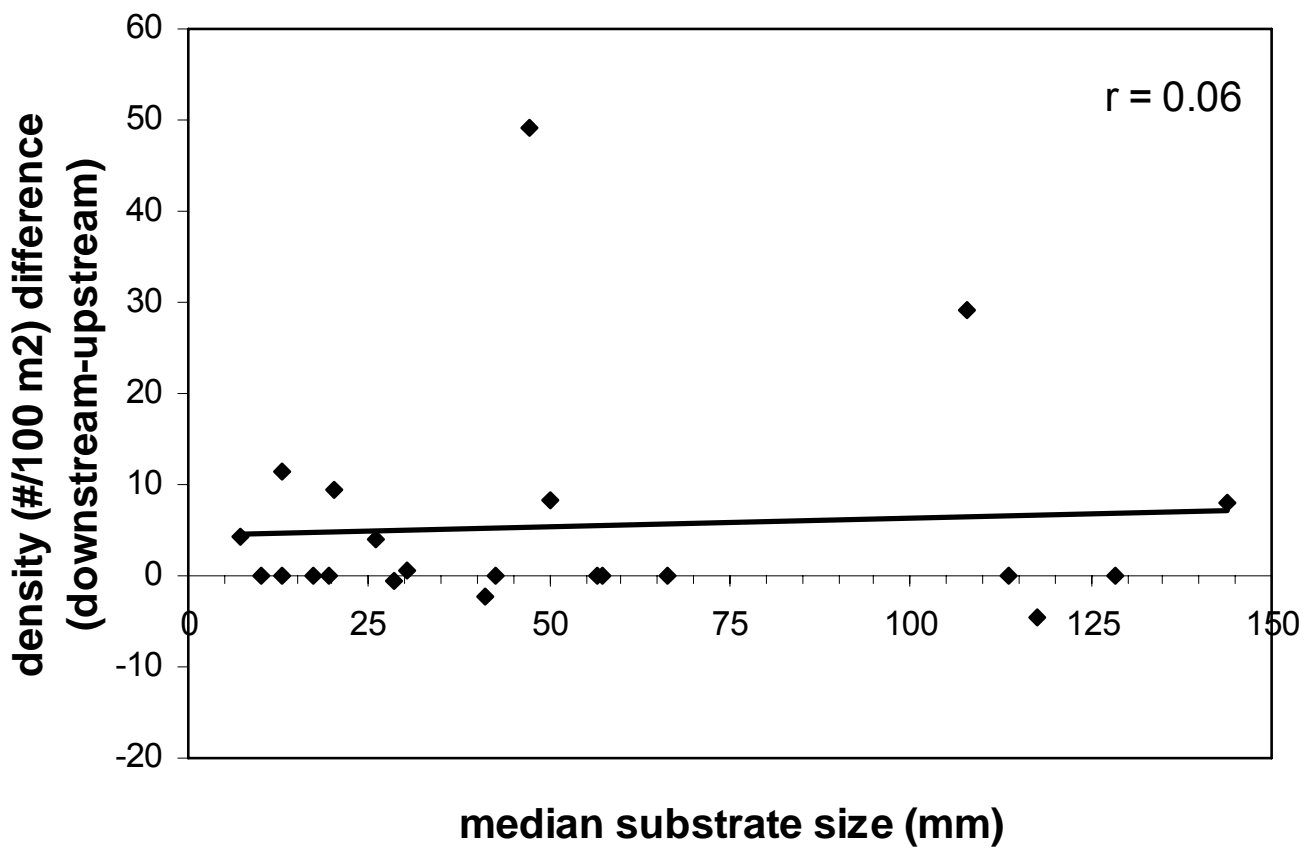


Figure 34: Percent of culvert sites where a given species was present upstream of the culvert versus the upstream extent of the species core range (Freund 2004), in basin area $\left(\mathrm{km}^{2}\right)$.

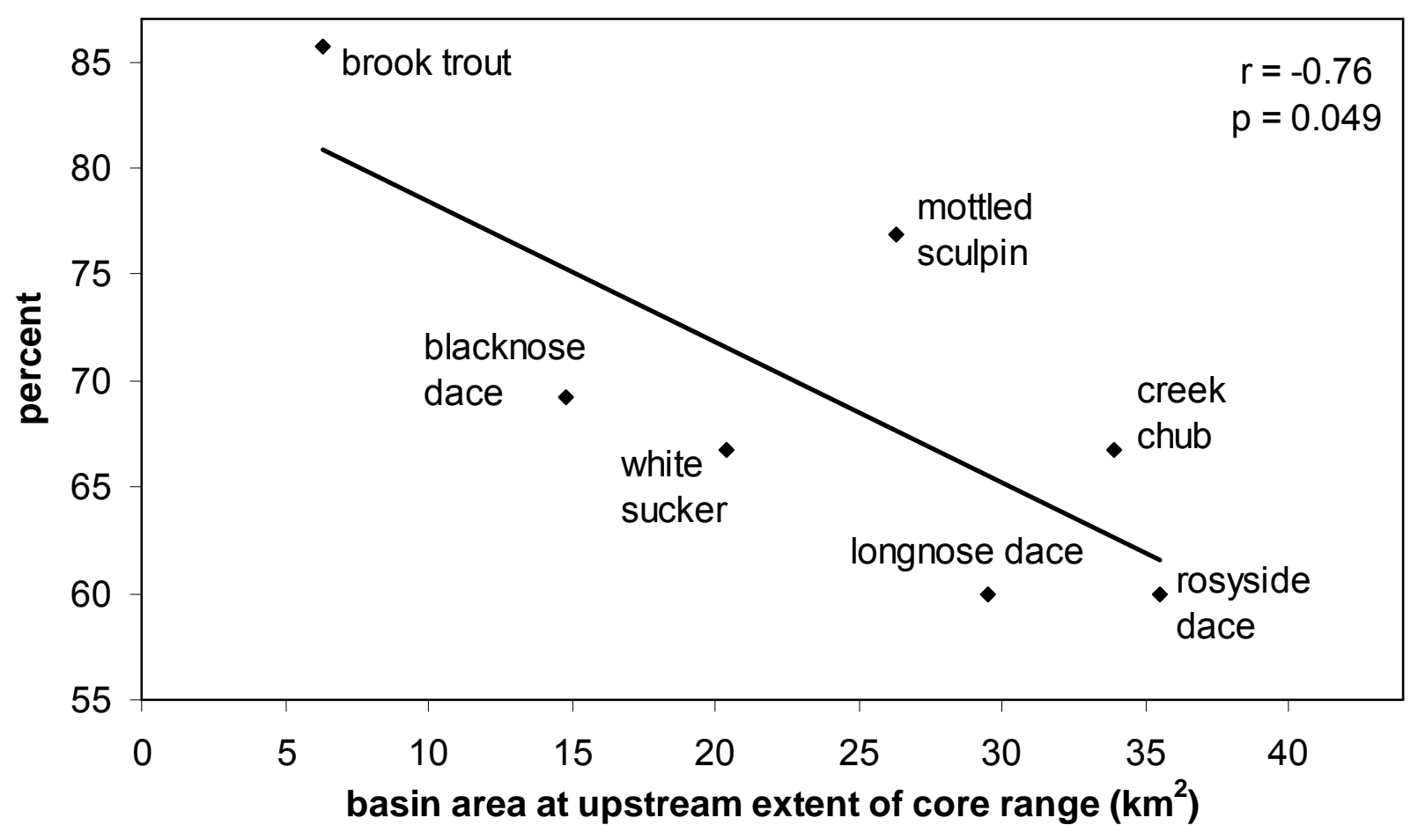


Appendix I: List of stream restoration opportunities at culvert crossings prioritized for fish passage restoration potential. The culverts are sorted first by salmonid passage category (red, gray, green) and then by weighted potential brook trout spawning area (WPRA; km). The abbreviation "CR" stands for "county road" and "UT" stands for "unnamed tributary."

\begin{tabular}{|c|c|c|c|c|c|c|c|}
\hline $\begin{array}{l}\text { Site } \\
\#\end{array}$ & Road \# & UTM E & UTM N & $\begin{array}{l}\text { Stream } \\
\text { Name }\end{array}$ & $\begin{array}{l}\text { Study } \\
\text { Section }\end{array}$ & $\begin{array}{l}\text { Passage } \\
\text { Category }\end{array}$ & $\begin{array}{c}\text { Upstream } \\
\text { WPRA } \\
(\mathrm{km})\end{array}$ \\
\hline 96 & CR 72 & 0627729 & 4320101 & $\begin{array}{l}\text { Elk Lick } \\
\text { Run }\end{array}$ & $\begin{array}{l}\text { lower Dry } \\
\text { Fork }\end{array}$ & Red & 8.68 \\
\hline 123 & CR 72 & 0630242 & 4317829 & Big Run & $\begin{array}{c}\text { lower Dry } \\
\text { Fork }\end{array}$ & Red & 5.13 \\
\hline 144 & CR 6 & 0609990 & 4315799 & $\begin{array}{l}\text { Little Laurel } \\
\text { Run }\end{array}$ & $\begin{array}{l}\text { Shavers } \\
\text { Fork }\end{array}$ & Red & 4.66 \\
\hline 139 & CR 6 & 0611869 & 4318712 & UT & $\begin{array}{c}\text { Shavers } \\
\text { Fork }\end{array}$ & Red & 3.67 \\
\hline 361 & CR 29-2 & 0625859 & 4297562 & UT & $\begin{array}{l}\text { upper Dry } \\
\text { Fork }\end{array}$ & Red & 3.41 \\
\hline 379 & CR 29 & 0626319 & 4295298 & $\begin{array}{l}\text { Lower Two } \\
\text { Spring Run }\end{array}$ & $\begin{array}{l}\text { upper Dry } \\
\text { Fork }\end{array}$ & Red & 3.35 \\
\hline 452 & CR 40 & 0619183 & 4286108 & $\begin{array}{l}\text { Warner } \\
\text { Run }\end{array}$ & $\begin{array}{l}\text { upper Dry } \\
\text { Fork }\end{array}$ & Red & 3.07 \\
\hline 28 & CR 219 & 0613528 & 4327219 & $\begin{array}{c}\text { Sugar } \\
\text { Camp Run }\end{array}$ & $\begin{array}{l}\text { Shavers } \\
\text { Fork }\end{array}$ & Red & 3.03 \\
\hline 140 & CR 6 & 0611677 & 4318373 & UT & $\begin{array}{c}\text { Shavers } \\
\text { Fork }\end{array}$ & Red & 3.00 \\
\hline 439 & CR 29 & 0620389 & 4287348 & $\begin{array}{l}\text { Grants } \\
\text { Branch }\end{array}$ & $\begin{array}{l}\text { upper Dry } \\
\text { Fork }\end{array}$ & Red & 2.82 \\
\hline 142 & CR 6 & 0610257 & 4316730 & $\begin{array}{l}\text { Wamsley } \\
\text { Run }\end{array}$ & $\begin{array}{l}\text { Shavers } \\
\text { Fork }\end{array}$ & Red & 2.81 \\
\hline 218 & CR 6 & 0606940 & 4310105 & $\begin{array}{l}\text { Walker } \\
\text { Run }\end{array}$ & $\begin{array}{c}\text { Shavers } \\
\text { Fork }\end{array}$ & Red & 2.80 \\
\hline 135 & CR 41 & 0611229 & 4322162 & $\begin{array}{l}\text { Stonelick } \\
\text { Run }\end{array}$ & $\begin{array}{l}\text { Shavers } \\
\text { Fork }\end{array}$ & Red & 2.74 \\
\hline 240 & CR 32-8 & 0606199 & 4302758 & Wolf Run & $\begin{array}{c}\text { Shavers } \\
\text { Fork }\end{array}$ & Red & 2.64 \\
\hline 84 & CR 47 & 0607396 & 4321337 & $\begin{array}{l}\text { Little Laurel } \\
\text { Run }\end{array}$ & $\begin{array}{l}\text { Shavers } \\
\text { Fork }\end{array}$ & Red & 2.46 \\
\hline 114 & CR 72 & 0628958 & 4318824 & $\begin{array}{l}\text { Pond } \\
\text { Creek }\end{array}$ & $\begin{array}{c}\text { lower Dry } \\
\text { Fork }\end{array}$ & Red & 2.35 \\
\hline 394 & CR 29 & 0625417 & 4294076 & $\begin{array}{l}\text { Upper Two } \\
\text { Spring Run }\end{array}$ & $\begin{array}{l}\text { upper Dry } \\
\text { Fork }\end{array}$ & Red & 2.23 \\
\hline 262 & CR 5-12 & 0606821 & 4307407 & $\begin{array}{c}\text { Spruce } \\
\text { Run }\end{array}$ & $\begin{array}{c}\text { Shavers } \\
\text { Fork }\end{array}$ & Red & 2.20 \\
\hline 116 & CR 72 & 0629033 & 4318822 & UT & $\begin{array}{l}\text { lower Dry } \\
\text { Fork }\end{array}$ & Red & 2.20 \\
\hline 132 & CR 7 & 0610815 & 4318805 & Natt Run & $\begin{array}{l}\text { Shavers } \\
\text { Fork }\end{array}$ & Red & 1.89 \\
\hline 407 & CR 40 & 0621449 & 4294629 & UT & $\begin{array}{l}\text { upper Dry } \\
\text { Fork }\end{array}$ & Red & 1.66 \\
\hline 369 & CR 22 & 0608180 & 4298625 & UT & $\begin{array}{l}\text { Shavers } \\
\text { Fork }\end{array}$ & Red & 1.50 \\
\hline
\end{tabular}




\begin{tabular}{|c|c|c|c|c|c|c|c|}
\hline 130 & $\begin{array}{c}\text { CR 35- } \\
16\end{array}$ & 0627393 & 4316818 & UT & $\begin{array}{l}\text { lower Dry } \\
\text { Fork }\end{array}$ & Red & 1.49 \\
\hline 115 & CR 39 & 0611005 & 4320053 & Laurel Run & $\begin{array}{l}\text { Shavers } \\
\text { Fork }\end{array}$ & Red & 1.48 \\
\hline 93 & CR 72 & 0624066 & 4320352 & UT & $\begin{array}{l}\text { lower Dry } \\
\text { Fork }\end{array}$ & Red & 1.46 \\
\hline 95 & $\begin{array}{c}\text { CR 43- } \\
11\end{array}$ & 0628051 & 4320031 & UT & $\begin{array}{l}\text { lower Dry } \\
\text { Fork }\end{array}$ & Red & 1.40 \\
\hline 334 & CR 31 & 0627648 & 4301415 & $\begin{array}{l}\text { Stenking } \\
\text { Creek }\end{array}$ & $\begin{array}{l}\text { lower Dry } \\
\text { Fork }\end{array}$ & Red & 1.34 \\
\hline 136 & CR 41 & 0611628 & 4321177 & $\begin{array}{c}\text { Sugarcamp } \\
\text { Run }\end{array}$ & $\begin{array}{l}\text { Shavers } \\
\text { Fork }\end{array}$ & Red & 1.31 \\
\hline 390 & CR 29 & 0626143 & 4294829 & UT & $\begin{array}{l}\text { upper Dry } \\
\text { Fork }\end{array}$ & Red & 1.31 \\
\hline 267 & CR 5-12 & 0609236 & 4307504 & UT & $\begin{array}{l}\text { Shavers } \\
\text { Fork }\end{array}$ & Red & 1.27 \\
\hline 138 & CR 41 & 0612396 & 4319697 & $\begin{array}{c}\text { Rock } \\
\text { Camp Run }\end{array}$ & $\begin{array}{l}\text { Shavers } \\
\text { Fork }\end{array}$ & Red & 1.26 \\
\hline 143 & CR 6 & 0609975 & 4315999 & UT & $\begin{array}{c}\text { Shavers } \\
\text { Fork }\end{array}$ & Red & 1.25 \\
\hline 73 & CR 47 & 0609648 & 4322217 & $\begin{array}{l}\text { Panther } \\
\text { Fork }\end{array}$ & $\begin{array}{l}\text { Shavers } \\
\text { Fork }\end{array}$ & Red & 1.24 \\
\hline 264 & CR 5-12 & 0610552 & 4307334 & UT & $\begin{array}{l}\text { Shavers } \\
\text { Fork }\end{array}$ & Red & 1.21 \\
\hline 91 & CR 72 & 0625945 & 432164 & UT & $\begin{array}{l}\text { lower Dry } \\
\text { Fork }\end{array}$ & Red & 1.14 \\
\hline 239 & CR 6 & 0607192 & 4309013 & UT & $\begin{array}{c}\text { Shavers } \\
\text { Fork }\end{array}$ & Red & 1.14 \\
\hline 432 & CR 40 & 0617983 & 4288960 & UT & $\begin{array}{l}\text { upper Dry } \\
\text { Fork }\end{array}$ & Red & 1.14 \\
\hline 193 & CR 9 & 0606217 & 4313240 & UT & $\begin{array}{l}\text { Shavers } \\
\text { Fork }\end{array}$ & Red & 1.13 \\
\hline 252 & CR 33-8 & 0607062 & 4307441 & UT & $\begin{array}{l}\text { Shavers } \\
\text { Fork }\end{array}$ & Red & 1.13 \\
\hline 266 & CR 5-12 & 0609371 & 4307367 & UT & $\begin{array}{l}\text { Shavers } \\
\text { Fork }\end{array}$ & Red & 1.12 \\
\hline 343 & CR 29 & 0624908 & 4302041 & UT & $\begin{array}{l}\text { lower Dry } \\
\text { Fork }\end{array}$ & Red & 1.11 \\
\hline 201 & CR 32-6 & 0629898 & 4311650 & UT & $\begin{array}{l}\text { lower Dry } \\
\text { Fork }\end{array}$ & Red & 1.06 \\
\hline 295 & CR 5-17 & 0631773 & $\begin{array}{c}4306251 \\
.8\end{array}$ & UT & $\begin{array}{l}\text { lower Dry } \\
\text { Fork }\end{array}$ & Red & 1.04 \\
\hline 97 & CR 72 & 0627492 & 4320119 & UT & $\begin{array}{l}\text { lower Dry } \\
\text { Fork }\end{array}$ & Red & 1.03 \\
\hline 251 & CR 33-8 & 0608696 & 4308101 & UT & $\begin{array}{c}\text { Shavers } \\
\text { Fork }\end{array}$ & Red & 1.02 \\
\hline 90 & CR 39 & 0611137 & 4321447 & UT & $\begin{array}{l}\text { Shavers } \\
\text { Fork }\end{array}$ & Red & 1.00 \\
\hline 297 & CR 29 & 0626259 & 4307363 & UT & $\begin{array}{l}\text { lower Dry } \\
\text { Fork }\end{array}$ & Red & 0.98 \\
\hline 363 & CR 40 & 0622965 & 4297719 & UT & $\begin{array}{l}\text { upper Dry } \\
\text { Fork }\end{array}$ & Red & 0.97 \\
\hline 406 & CR 40 & 0622036 & 4295757 & UT & $\begin{array}{l}\text { upper Dry } \\
\text { Fork }\end{array}$ & Red & 0.97 \\
\hline
\end{tabular}




\begin{tabular}{|c|c|c|c|c|c|c|c|}
\hline 10 & CR 219 & 0607704 & 4327895 & UT & $\begin{array}{c}\text { Shavers } \\
\text { Fork }\end{array}$ & Red & 0.96 \\
\hline 371 & CR 40 & 0622436 & 4297353 & UT & $\begin{array}{l}\text { upper Dry } \\
\text { Fork }\end{array}$ & Red & 0.95 \\
\hline 238 & CR 6 & 0607249 & 4309174 & $\begin{array}{l}\text { Western } \\
\text { Run }\end{array}$ & $\begin{array}{c}\text { Shavers } \\
\text { Fork }\end{array}$ & Red & 0.95 \\
\hline 344 & CR 29 & 0624749 & 4301468 & UT & $\begin{array}{c}\text { lower Dry } \\
\text { Fork }\end{array}$ & Red & 0.94 \\
\hline 420 & CR 29 & 0621959 & 4289631 & $\begin{array}{l}\text { Nans } \\
\text { Branch }\end{array}$ & $\begin{array}{l}\text { upper Dry } \\
\text { Fork }\end{array}$ & Red & 0.93 \\
\hline 98 & CR 72 & 0628218 & 4319698 & UT & $\begin{array}{c}\text { lower Dry } \\
\text { Fork }\end{array}$ & Red & 0.93 \\
\hline 316 & CR 29 & 0624704 & 4304215 & UT & $\begin{array}{c}\text { lower Dry } \\
\text { Fork }\end{array}$ & Red & 0.92 \\
\hline 86 & CR 47 & 0606343 & 4321398 & $\begin{array}{l}\text { Choke } \\
\text { Trap Run }\end{array}$ & $\begin{array}{l}\text { Shavers } \\
\text { Fork }\end{array}$ & Red & 0.88 \\
\hline 121 & CR 26 & 0624729 & 4318741 & UT & $\begin{array}{l}\text { lower Dry } \\
\text { Fork }\end{array}$ & Red & 0.88 \\
\hline 319 & CR 29-3 & 0624927 & 4303235 & UT & $\begin{array}{l}\text { lower Dry } \\
\text { Fork }\end{array}$ & Red & 0.86 \\
\hline 9 & CR 219 & 0608469 & 4328027 & UT & $\begin{array}{l}\text { Shavers } \\
\text { Fork }\end{array}$ & Red & 0.82 \\
\hline 194 & CR 9 & 0605970 & 4312514 & UT & $\begin{array}{l}\text { Shavers } \\
\text { Fork }\end{array}$ & Red & 0.82 \\
\hline 265 & CR 5-12 & 0609733 & 4307219 & UT & $\begin{array}{l}\text { Shavers } \\
\text { Fork }\end{array}$ & Red & 0.80 \\
\hline 244 & CR 33-8 & 0610236 & 4307641 & UT & $\begin{array}{c}\text { Shavers } \\
\text { Fork }\end{array}$ & Red & 0.76 \\
\hline 418 & CR 29 & 0622848 & 4290736 & UT & $\begin{array}{l}\text { upper Dry } \\
\text { Fork }\end{array}$ & Red & 0.71 \\
\hline 24 & CR 219 & 0608878 & 4327837 & UT & $\begin{array}{c}\text { Shavers } \\
\text { Fork }\end{array}$ & Red & 0.70 \\
\hline 15 & CR 219 & 0605267 & 4327751 & UT & $\begin{array}{c}\text { Shavers } \\
\text { Fork }\end{array}$ & Red & 0.70 \\
\hline 83 & CR 43-6 & 0626356 & 4322118 & Mill Run & $\begin{array}{c}\text { lower Dry } \\
\text { Fork }\end{array}$ & Red & 0.69 \\
\hline 107 & $\begin{array}{c}\text { CR 43- } \\
12\end{array}$ & 0627157 & 4319332 & $\begin{array}{l}\text { Elk Lick } \\
\text { Run }\end{array}$ & $\begin{array}{l}\text { lower Dry } \\
\text { Fork }\end{array}$ & Red & 0.66 \\
\hline 206 & CR 9-4 & 0605999 & 4310807 & UT & $\begin{array}{l}\text { Shavers } \\
\text { Fork }\end{array}$ & Red & 0.64 \\
\hline 268 & CR 5-12 & 0610956 & 4307260 & UT & $\begin{array}{c}\text { Shavers } \\
\text { Fork }\end{array}$ & Red & 0.64 \\
\hline 109 & CR 26 & 0623919 & 4319639 & UT & $\begin{array}{c}\text { lower Dry } \\
\text { Fork }\end{array}$ & Red & 0.63 \\
\hline 419 & CR 29 & 0622485 & 4290551 & UT & $\begin{array}{c}\text { upper Dry } \\
\text { Fork }\end{array}$ & Red & 0.60 \\
\hline 408 & CR 40 & 0621227 & 4293207 & UT & $\begin{array}{l}\text { upper Dry } \\
\text { Fork }\end{array}$ & Red & 0.59 \\
\hline 106 & $\begin{array}{c}\text { CR 43- } \\
11\end{array}$ & 0627641 & 4319775 & UT & $\begin{array}{l}\text { lower Dry } \\
\text { Fork }\end{array}$ & Red & 0.58 \\
\hline 440 & CR 40 & 0618550 & 4287467 & UT & $\begin{array}{c}\text { upper Dry } \\
\text { Fork }\end{array}$ & Red & 0.56 \\
\hline 133 & CR 7 & 0609821 & 4318164 & Flatbrush & $\begin{array}{c}\text { Shavers } \\
\text { Fork }\end{array}$ & Red & 0.51 \\
\hline 360 & CR 29-4 & 0626169 & 4297503 & UT & $\begin{array}{l}\text { upper Dry } \\
\text { Fork }\end{array}$ & Red & 0.51 \\
\hline
\end{tabular}




\begin{tabular}{|c|c|c|c|c|c|c|c|}
\hline 196 & CR 32-7 & 0628874 & 4312346 & UT & $\begin{array}{l}\text { lower Dry } \\
\text { Fork }\end{array}$ & Red & 0.48 \\
\hline 72 & $\begin{array}{c}\text { CR } 219- \\
7\end{array}$ & 0620423 & 4323808 & UT & $\begin{array}{l}\text { lower Dry } \\
\text { Fork }\end{array}$ & Red & 0.42 \\
\hline 293 & CR 25 & 0605757 & 4306211 & Wolf Run & $\begin{array}{c}\text { Shavers } \\
\text { Fork }\end{array}$ & Red & 0.40 \\
\hline 320 & CR 31 & 0624091 & 4303166 & UT & $\begin{array}{l}\text { lower Dry } \\
\text { Fork }\end{array}$ & Red & 0.22 \\
\hline 187 & CR 32-4 & 0628173 & 4212528 & UT & $\begin{array}{l}\text { lower Dry } \\
\text { Fork }\end{array}$ & Red & 0.14 \\
\hline 58 & CR 39 & 0612209 & 4324728 & Job Run & $\begin{array}{l}\text { Shavers } \\
\text { Fork }\end{array}$ & Red & 0.02 \\
\hline 102 & CR 47-2 & 0607424 & 4320780 & $\begin{array}{l}\text { Slabcamp } \\
\text { Run }\end{array}$ & $\begin{array}{c}\text { Shavers } \\
\text { Fork }\end{array}$ & Gray & 5.02 \\
\hline 85 & CR 72 & 0626265 & 4321380 & Mill Run & $\begin{array}{l}\text { lower Dry } \\
\text { Fork }\end{array}$ & Gray & 4.48 \\
\hline 170 & CR 32-7 & 0328971 & 4314610 & UT & $\begin{array}{l}\text { lower Dry } \\
\text { Fork }\end{array}$ & Gray & 4.34 \\
\hline 378 & CR 29 & 0626587 & 4296053 & UT & $\begin{array}{l}\text { upper Dry } \\
\text { Fork }\end{array}$ & Gray & 3.33 \\
\hline 137 & CR 41 & 0611534 & 4320995 & Canoe Run & $\begin{array}{c}\text { Shavers } \\
\text { Fork }\end{array}$ & Gray & 3.29 \\
\hline 186 & CR 32-4 & 0628045 & 4312675 & UT & $\begin{array}{l}\text { lower Dry } \\
\text { Fork }\end{array}$ & Gray & 3.12 \\
\hline 260 & CR 5-12 & 0607096 & 4307316 & UT & $\begin{array}{c}\text { Shavers } \\
\text { Fork }\end{array}$ & Gray & 2.75 \\
\hline 323 & CR 29 & 0625145 & 4302622 & UT & $\begin{array}{l}\text { lower Dry } \\
\text { Fork }\end{array}$ & Gray & 2.55 \\
\hline 443 & CR 29 & 0619983 & 4286494 & $\begin{array}{c}\text { Narrow } \\
\text { Ridge Run }\end{array}$ & $\begin{array}{l}\text { upper Dry } \\
\text { Fork }\end{array}$ & Gray & 2.39 \\
\hline 309 & CR 29 & 0625086 & 4304884 & UT & $\begin{array}{l}\text { lower Dry } \\
\text { Fork }\end{array}$ & Gray & 2.28 \\
\hline 346 & CR 29 & 0624316 & 4300107 & UT & $\begin{array}{l}\text { lower Dry } \\
\text { Fork }\end{array}$ & Gray & 2.12 \\
\hline 43 & CR 39-1 & 0611507 & 4324890 & Job Run & $\begin{array}{c}\text { Shavers } \\
\text { Fork }\end{array}$ & Gray & 1.94 \\
\hline 442 & CR 29 & 0619707 & 4286548 & $\begin{array}{c}\text { Devers } \\
\text { Run }\end{array}$ & $\begin{array}{l}\text { upper Dry } \\
\text { Fork }\end{array}$ & Gray & 1.74 \\
\hline 127 & $\begin{array}{c}\text { CR 53- } \\
13\end{array}$ & 0625985 & 4318363 & UT & $\begin{array}{l}\text { lower Dry } \\
\text { Fork }\end{array}$ & Gray & 1.69 \\
\hline 134 & CR 7 & $\begin{array}{c}0690938 \\
8\end{array}$ & 4317015 & Boar Run & $\begin{array}{l}\text { Shavers } \\
\text { Fork }\end{array}$ & Gray & 1.64 \\
\hline 237 & CR 6 & 0606811 & 4309838 & UT & $\begin{array}{c}\text { Shavers } \\
\text { Fork }\end{array}$ & Gray & 1.62 \\
\hline 366 & CR 29 & 0625897 & 4297114 & UT & $\begin{array}{l}\text { lower Dry } \\
\text { Fork }\end{array}$ & Gray & 1.33 \\
\hline 298 & CR 29 & 0626118 & 4306967 & UT & $\begin{array}{l}\text { lower Dry } \\
\text { Fork }\end{array}$ & Gray & 1.20 \\
\hline 37 & CR 219 & 0611155 & 4326294 & $\begin{array}{l}\text { Shingle } \\
\text { Tree Run }\end{array}$ & $\begin{array}{c}\text { Shavers } \\
\text { Fork }\end{array}$ & Gray & 1.17 \\
\hline 353 & CR 40 & 0623468 & 4297937 & UT & $\begin{array}{l}\text { lower Dry } \\
\text { Fork }\end{array}$ & Gray & 1.15 \\
\hline 188 & CR 32-4 & 0628225 & 4312510 & UT & $\begin{array}{c}\text { lower Dry } \\
\text { Fork }\end{array}$ & Gray & 1.05 \\
\hline
\end{tabular}




\begin{tabular}{|c|c|c|c|c|c|c|c|}
\hline 29 & CR 219 & 0612824 & 4326583 & Hawk Run & $\begin{array}{c}\text { Shavers } \\
\text { Fork }\end{array}$ & Gray & 1.04 \\
\hline 391 & CR 29 & 0626034 & 4294569 & UT & $\begin{array}{l}\text { upper Dry } \\
\text { Fork }\end{array}$ & Gray & 1.02 \\
\hline 14 & CR 219 & 0605618 & 4327876 & UT & $\begin{array}{l}\text { Shavers } \\
\text { Fork }\end{array}$ & Gray & 0.99 \\
\hline 421 & CR 29 & 0621666 & 4289312 & UT & $\begin{array}{l}\text { upper Dry } \\
\text { Fork }\end{array}$ & Gray & 0.97 \\
\hline 404 & CR 29 & 0623434 & 4291492 & Taylor Run & $\begin{array}{l}\text { upper Dry } \\
\text { Fork }\end{array}$ & Gray & 0.97 \\
\hline 101 & CR 67 & 0608488 & 4319669 & $\begin{array}{l}\text { Slabcamp } \\
\text { Run }\end{array}$ & $\begin{array}{l}\text { Shavers } \\
\text { Fork }\end{array}$ & Gray & 0.94 \\
\hline 299 & CR 29 & 0626033 & 4306180 & UT & $\begin{array}{l}\text { lower Dry } \\
\text { Fork }\end{array}$ & Gray & 0.91 \\
\hline 210 & CR 32 & 0628302 & 4310530 & UT & $\begin{array}{l}\text { lower Dry } \\
\text { Fork }\end{array}$ & Gray & 0.76 \\
\hline 365 & CR 29 & 0625165 & 4297841 & UT & $\begin{array}{l}\text { upper Dry } \\
\text { Fork }\end{array}$ & Gray & 0.64 \\
\hline 209 & CR 32-6 & 0628349 & 4310469 & UT & $\begin{array}{l}\text { lower Dry } \\
\text { Fork }\end{array}$ & Gray & 0.61 \\
\hline 44 & CR 39-1 & 0612019 & 4324907 & Job Run & $\begin{array}{l}\text { Shavers } \\
\text { Fork }\end{array}$ & Gray & 0.21 \\
\hline 45 & CR 39-1 & 0612123 & 4324830 & Job Run & $\begin{array}{c}\text { Shavers } \\
\text { Fork }\end{array}$ & Gray & 0.04 \\
\hline 100 & CR 67 & 0608486 & 4319705 & $\begin{array}{l}\text { Slabcamp } \\
\text { Run }\end{array}$ & $\begin{array}{c}\text { Shavers } \\
\text { Fork }\end{array}$ & Gray & 0.01 \\
\hline 377 & CR 29 & 0626562 & 4296200 & UT & $\begin{array}{l}\text { upper Dry } \\
\text { Fork }\end{array}$ & Green & 2.48 \\
\hline 434 & CR 29 & 0621334 & 4288585 & UT & $\begin{array}{l}\text { upper Dry } \\
\text { Fork }\end{array}$ & Green & 1.83 \\
\hline 195 & CR 32-7 & 0629393 & 4312530 & UT & $\begin{array}{c}\text { lower Dry } \\
\text { Fork }\end{array}$ & Green & 0.73 \\
\hline
\end{tabular}


Appendix II: Site information for culverts studied in chapter 3.

\begin{tabular}{|c|c|c|c|c|c|c|c|c|}
\hline $\begin{array}{l}\text { culvert } \\
\text { number }\end{array}$ & study section & $\begin{array}{l}\text { basin } \\
\text { area } \\
(\mathrm{km} 2)\end{array}$ & $\begin{array}{l}\text { reach } \\
\text { length }(\mathrm{m}) \\
\text { upstream } \\
\end{array}$ & $\begin{array}{c}\text { reach } \\
\text { length }(\mathrm{m}) \\
\text { downstream }\end{array}$ & $\begin{array}{l}\text { mean stream } \\
\text { width }(\mathrm{m}) \\
\text { upstream }\end{array}$ & $\begin{array}{l}\text { mean stream } \\
\text { width }(\mathrm{m}) \\
\text { downstream }\end{array}$ & $\begin{array}{c}\text { species } \\
\text { richness } \\
\text { upstream } \\
\end{array}$ & $\begin{array}{c}\text { species } \\
\text { richness } \\
\text { downstream }\end{array}$ \\
\hline 412 & Glady Fork & 0.41 & 150 & 50 & 1 & 1.2 & 0 & 2 \\
\hline 447 & Glady Fork & 0.43 & 150 & - & 1 & - & 2 & - \\
\hline 345 & Glady Fork & 0.48 & 150 & 150 & 2.2 & 2.2 & 1 & 2 \\
\hline 383 & Glady Fork & 0.56 & 150 & 50 & 1.3 & 1.3 & 0 & 0 \\
\hline 200 & Glady Fork & 0.61 & 150 & 150 & 2 & 2.4 & 1 & 2 \\
\hline 430 & Glady Fork & 0.76 & 150 & - & 1.3 & - & 1 & - \\
\hline 179 & Glady Fork & 0.92 & 150 & - & 1.7 & - & 1 & - \\
\hline 181 & Glady Fork & 0.94 & 150 & - & 1.6 & - & 2 & - \\
\hline 415 & Glady Fork & 1.3 & 150 & 65 & 1.9 & 2.3 & 2 & 3 \\
\hline
\end{tabular}




\begin{tabular}{|c|c|c|c|c|c|c|c|c|}
\hline 448 & Glady Fork & 1.42 & 150 & 150 & 1.5 & 1.5 & 2 & 5 \\
\hline 417 & Glady Fork & 1.45 & 150 & 50 & 2.5 & 3 & 2 & 4 \\
\hline 175 & Glady Fork & 1.82 & 150 & - & 1.9 & - & 1 & - \\
\hline 177 & Glady Fork & 2.3 & 150 & - & 4.1 & - & 11 & - \\
\hline 410 & Glady Fork & 2.93 & 150 & - & 2.7 & - & 3 & - \\
\hline 190 & Glady Fork & 4.75 & 150 & 150 & 2.6 & 3.8 & 3 & 3 \\
\hline 431 & Glady Fork & 6.15 & 150 & 150 & 3.9 & 4.6 & 8 & 8 \\
\hline 416 & Glady Fork & 12.7 & 150 & 150 & 4.2 & 3.8 & 9 & 9 \\
\hline 295 & Lower Dry Fork & 0.52 & 150 & - & 1.3 & - & 0 & - \\
\hline 312 & Lower Dry Fork & 0.53 & 150 & - & 1.7 & - & 0 & - \\
\hline 97 & Lower Dry Fork & 0.58 & 150 & 150 & 1.6 & 2.8 & 0 & 0 \\
\hline 121 & Lower Dry Fork & 0.61 & 150 & 150 & 1.7 & 1.4 & 0 & 0 \\
\hline
\end{tabular}




\begin{tabular}{|c|c|c|c|c|c|c|c|}
\hline 201 & Lower Dry Fork & 0.94 & 150 & 150 & 1.7 & 1.9 & 0 \\
\hline 93 & Lower Dry Fork & 1.18 & 150 & 150 & 1.6 & 1.9 & 0 \\
\hline 130 & Lower Dry Fork & 1.49 & 150 & - & 2.8 & - & 0 \\
\hline 186 & Lower Dry Fork & 1.57 & 150 & 150 & 2.4 & 2.4 & 1 \\
\hline 188 & Lower Dry Fork & 2.38 & 150 & 150 & 2.4 & 2.5 & 1 \\
\hline 323 & Lower Dry Fork & 2.53 & 150 & - & 3 & - & 3 \\
\hline 196 & Lower Dry Fork & 2.84 & 150 & 150 & 2.9 & 2.2 & 3 \\
\hline 195 & Lower Dry Fork & 3.11 & 150 & - & 2.5 & - & 9 \\
\hline 123 & Lower Dry Fork & 3.73 & 150 & 150 & 2.3 & 1.9 & 2 \\
\hline 96 & Lower Dry Fork & 4.81 & 150 & 150 & 2.3 & 3.7 & 1 \\
\hline 107 & Lower Dry Fork & 7.26 & 150 & - & 4.1 & - & 4 \\
\hline 419 & Upper Dry Fork & 0.43 & 150 & - & 1.7 & - & 0 \\
\hline
\end{tabular}




\begin{tabular}{|c|c|c|c|c|c|c|c|}
\hline 418 & Upper Dry Fork & 0.47 & 150 & - & 1.3 & - & 0 \\
\hline 421 & Upper Dry Fork & 0.85 & 150 & 125 & 1.8 & 1.3 & 2 \\
\hline 420 & Upper Dry Fork & 0.97 & 150 & 90 & 1.8 & 2 & 2 \\
\hline 434 & Upper Dry Fork & 1.09 & 150 & - & 1.5 & - & 1 \\
\hline 442 & Upper Dry Fork & 1.1 & 150 & - & 2.3 & - & 1 \\
\hline 377 & Upper Dry Fork & 1.29 & 150 & - & 1.2 & - & 0 \\
\hline 432 & Upper Dry Fork & 1.81 & 150 & 150 & 2.1 & 1.6 & 2 \\
\hline 405 & Upper Dry Fork & 2.12 & 150 & - & 2.6 & - & 5 \\
\hline 452 & Upper Dry Fork & 2.63 & 150 & 150 & 2.2 & 2.3 & 3 \\
\hline 439 & Upper Dry Fork & 3.5 & 150 & - & 2.9 & - & 2 \\
\hline 443 & Upper Dry Fork & 3.5 & 150 & 130 & 3 & 3.5 & 3 \\
\hline 361 & Upper Dry Fork & 3.6 & 150 & - & 1.9 & - & 5 \\
\hline
\end{tabular}


